Florida International University FIU Digital Commons

FIU Electronic Theses and Dissertations

University Graduate School

3-24-2015

\title{
Estrategias Desestabilizadoras en la Narrativa de Silvina Ocampo
}

Lorena Loguzzo

Florida International University, llogu001@fiu.edu

DOI: $10.25148 /$ etd.FI15032156

Follow this and additional works at: https://digitalcommons.fiu.edu/etd

Part of the Feminist, Gender, and Sexuality Studies Commons, Latin American Literature Commons, and the Modern Languages Commons

\section{Recommended Citation}

Loguzzo, Lorena, "Estrategias Desestabilizadoras en la Narrativa de Silvina Ocampo" (2015). FIU Electronic Theses and Dissertations. 1838 .

https://digitalcommons.fiu.edu/etd/1838

This work is brought to you for free and open access by the University Graduate School at FIU Digital Commons. It has been accepted for inclusion in FIU Electronic Theses and Dissertations by an authorized administrator of FIU Digital Commons. For more information, please contact dcc@fiu.edu. 


\section{FLORIDA INTERNATIONAL UNIVERSITY}

Miami, Florida

\section{ESTRATEGIAS DESESTABILIZADORAS EN LA NARRATIVA DE SILVINA OCAMPO}

A dissertation submitted in partial fulfillment of the requirements for the degree of

DOCTOR OF PHILOSOPHY

in

SPANISH

by

Lorena Loguzzo

2015 
To: Dean Michael R. Heithaus

College of Arts and Sciences

This dissertation, written by Lorena Loguzzo, and entitled Estratregias Desestabilizadoras en la Narrativa de Silvina Ocampo, having been approved in respect to style and intellectual content, is referred to you for judgment.

We have read this dissertation and recommend that it be approved.

Santiago Juan-Navarro

Joan Torres-Pou

Sherry Johnson

Erik Camayd-Freixas, Co-Major Professor

Andrea Fanta, Co-Major Professor

Date of Defense: March 24, 2015

The dissertation of Lorena Loguzzo is approved.

\begin{tabular}{r}
\hline $\begin{array}{r}\text { Dean Michael R. Heithaus } \\
\text { College of Arts and Sciences }\end{array}$ \\
\hline Dean Lakshmi N. Reddi \\
University Graduate School
\end{tabular}

Florida International University, 2015 


\section{DEDICATORIA}

A Carla, Mary Rose, Ricardo, Florencia, Patricio, Verónica, Raffaella, Federico, Andrea, Valentino y Antonella.

SDG 


\section{AGRADECIMIENTOS}

Agradezco profundamente a los miembros de mi comité, Dra. Andrea Fanta, Dr. Erik Camayd-Freixas, Dr. Santiago Juan-Navarro, Dr. Joan Torres-Pou y Dra. Sherry Johnson, por su aliento, orientación, observaciones y apoyo en el curso de mi investigación y estudios.

A la Dra. María Asunción Gómez, quien me animó a seguir el doctorado.

Al Departamento de Lenguas Modernas, por la beca Graduate Teaching Assistantship.

A la Fundación Tinker [Tinker Foundation], al centro de Estudios Latinoamericanos y del Caribe y al Centro de Estudios Transnacionales y Comparados de FIU, por la beca Tinker Field Research Grant que me permitió recabar datos y publicaciones sobre Silvina Ocampo en Argentina que de otro modo no hubiera podido conseguir.

A la Dra. Adriana Mancini, Profesora de la Universidad de Buenos Aires, por la oportunidad de tratar su trabajo pionero sobre Ocampo y por los artículos que me prestó de su archivo personal. 


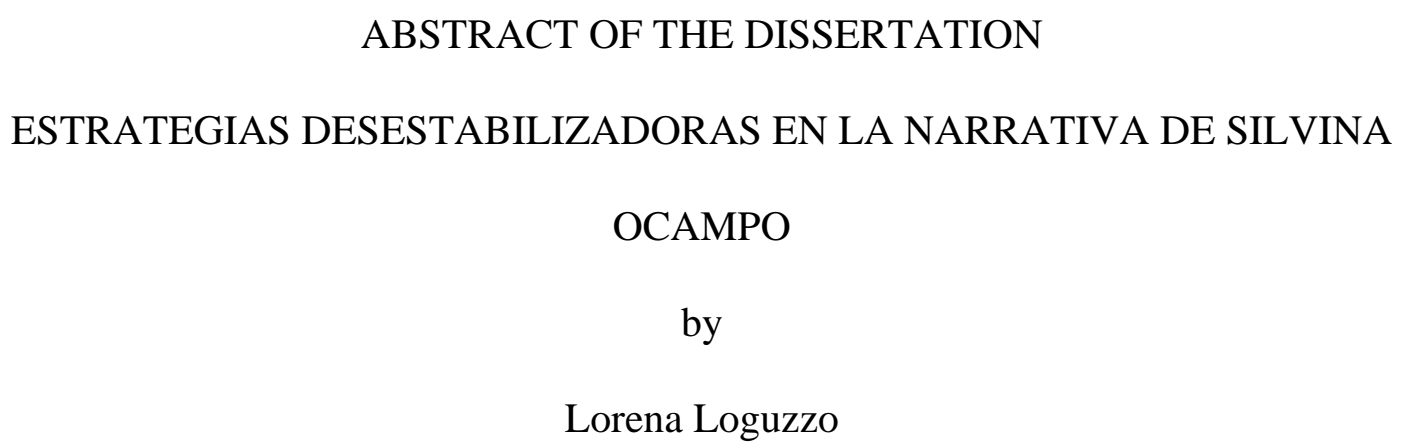

Florida International University, 2015

Miami, Florida

Professor Erik Camayd-Freixas, Co-Major Professor

Professor Andrea Fanta, Co-Major Professor

La narrativa de Silvina Ocampo (1903-1993) no goza del lugar que merece en la ficción argentina y latinoamericana como obra de la principal cuentista del siglo XX. Hace relativamente poco que su obra comenzó a despertar el interés de la crítica, atención que se evidencia en la cantidad de artículos y disertaciones recientes.

Mediante una disección de la narrativa ocampeana a partir de las grandes coordenadas que la intersectan se pueden caracterizar los aspectos peculiares y distintivos de su estilo. Desarrollada tras la consolidación del psicoanálisis y su influencia en la estética surrealista, la narrativa de Ocampo incorpora algunos de esos elementos. El género fantástico también se articula aunque mediante una selección de rasgos configurados a su modo. Si bien Ocampo rechaza la etiqueta de feminista, ciertos aspectos de su estilo sólo pueden explicarse a partir de la visión particular de una mujer escritora y su representación de la identidad y las relaciones. 
La lectura pormenorizada de varios cuentos recogidos en “Cuentos completos” I y II (1999), once volúmenes publicados durante su vida, pertenecientes a distintos períodos de su producción permiten realizar un análisis diacrónico que ofrece una caracterización redonda de su estilo y evolución. El análisis sincrónico de estos textos incorpora datos históricos acerca del contexto de producción; a la vez que otras obras literarias del período ofrecen un punto de comparación para identificar influencias y contribuciones.

Este análisis, realizado desde el marco teórico de la crítica literaria, da cuenta de la presencia de constituyentes narrativos (narrador, ironía, ambigüedad) que configuran espacios de indeterminación, noción postulada por las teorías de la recepción. Éstos explican las peculiares características de la obra ocampeana: su habilidad para inquietar, intrigar, sorprender y, en suma, desestabilizar al lector y sus expectativas. Es más, sirven para explicar la idiosincrática representación de la realidad que emana de su obra, su interés en lo fantástico y la articulación de lo anti-convencional, como mecanismo subversivo para escapar del orden social dominante, lo cual revela sensibilidades protofeministas. La narrativa de Silvina Ocampo se resiste al reduccionismo y construye una visión peculiar y multifacética de la artista y su obra. 


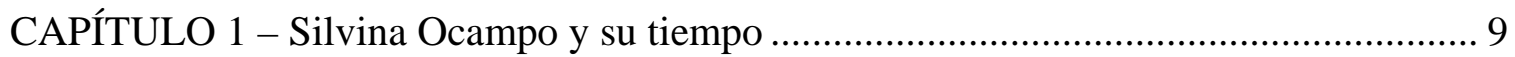

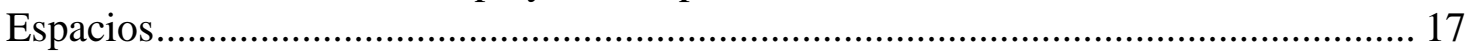

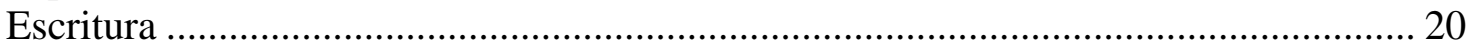

Obras en colaboración y dispersas ............................................................................. 23

Labor como traductora - Revista Sur..................................................................... 28

La infancia en la obra de Ocampo........................................................................ 31

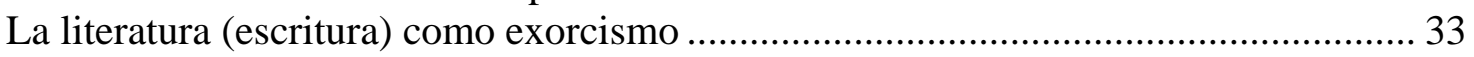

Ocampo y las letras femeninas............................................................................ 36

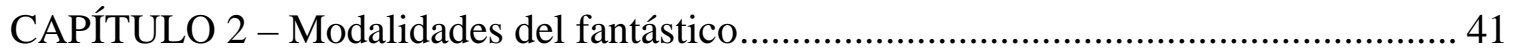

Antecedentes en el Río de la Plata ........................................................................... 43

El conflicto en "Viaje olvidado" ................................................................................ 48

El lenguaje creador y "El castigo" ................................................................................ 53

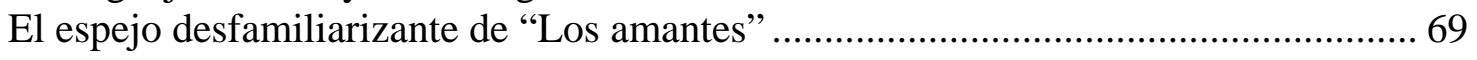

CAPÍTULO 3 - La exploración de los andamios de la identidad ...................................... 76

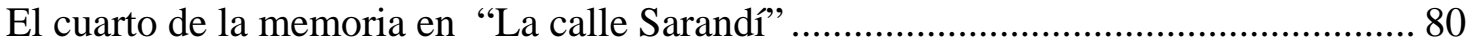

El espejo de la escritura en "Voz en el teléfono" ............................................................ 86

La fragmentación de la identidad en "Cornelia frente al espejo" ................................ 105

CAPÍTULO 4 - Silvina Ocampo y la escritura femenina .............................................. 117

Mostrar vs. ocultar y ser vs. parecer en "El vestido verde aceituna"............................. 120

Rito, castigo y muerte en "El vestido de terciopelo" ..................................................... 143

Agencialidad del deseo y subversión en "Las vestiduras peligrosas”.......................... 152

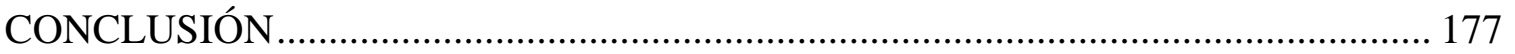

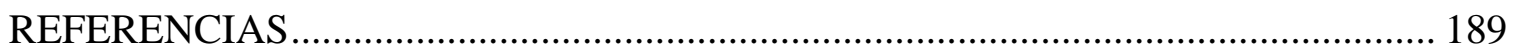

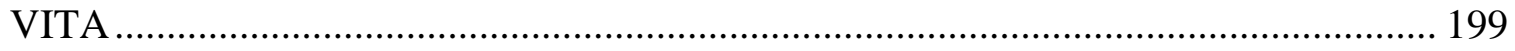




\section{INTRODUCCIÓN}

¿Cómo se hace un retrato de un autor que insiste en permanecer oculto en las sombras? ¿Cómo llegar a conocer un autor que se aleja de la luz pública y no duda en señalar las fallas o la incomodidad de su estilo en la rara ocasión en que conceda una entrevista? ¿Cómo indagar sobre la vida de un autor cuya biografía parece una tarea imposible de realizar? Quizás sea precisamente esa falta de detalles acerca de su vida, y su deliberada huida de la vida pública del escritor lo que motive el deseo de llenar esos vacíos de conocimiento, un ejercicio fascinante tanto para el público en general como para el ámbito académico. Tal es el caso de Silvina Ocampo. Pocas veces se encuentra su nombre solo, sin inmediata mención de su famoso cónyuge, Adolfo Bioy Casares, su ilustre amigo, Jorge Luis Borges, y su famosa hermana mayor, Victoria Ocampo, ineludibles señas de su carta de presentación. Estas referencias ineludibles que uno encuentra en cualquier indagación sobre la autora casi adquieren la forma del cliché obligatorio que adorna la mención de su nombre, como si eso fuera, desde el saber compartido, lo único que valiera la pena mencionar acerca de Ocampo, o, peor aún, el dato que lo dice todo.

Muy por el contrario, la carrera literaria de Ocampo no se funda en sus relaciones de parentesco o amistad. No es el resultado del capricho ni el hobby de una dama de la alta burguesía argentina que busca llenar sus horas de ocio sino una elección de vida, una carrera que define su identidad, la respuesta a una vocación de profundo arraigo y la expresión de un talento singular. El hecho de que comparativamente se haya dicho, escrito y tratado tan poco acerca de Silvina Ocampo y su obra sólo sirve para acrecentar 
la fascinación del misterio que representa. Sería erróneo, empero, dar a entender que el interés por ella es simplemente circunstancial o secundario: se funda en una producción literaria que abarca toda su vida, una obra singular e idiosincrática como su autora, un esfuerzo pionero que irrumpe en la historia del cuento en las letras hispanas del siglo XX para dejar su marca.

Las historias de Ocampo, que exhiben una cuidada y minuciosa construcción, se revelan como el producto de una artista en una búsqueda permanente de pulir y perfeccionar su arte. Su auto proclamada “dificultad con la estructura y la gramática” se explica generalmente por el hecho de que su educación temprana se llevó a cabo en francés y en inglés, antes que en español, el idioma de su país natal. Además del evidente tono de modestia, quasi despectivo, que comúnmente los autores adoptan al hablar de su obra, esta declaración enmascara la arraigada preocupación de Ocampo por perfeccionar su trabajo, la búsqueda del autor del vehículo adecuado para plasmar su ímpetu creativo.

Ocampo también afirmó: "pinto lo que no puedo escribir y escribo lo que no puedo pintar" dando testimonio de primera mano del hecho de que las ideas, la visión, las preocupaciones y las obsesiones de la artista solo necesitaban encontrar la salida adecuada, el medio de expresión ideal; y que su genialidad reside en su habilidad singular para transponer las herramientas y los recursos de cada ámbito para conjurar los cuentos más conmovedores, poéticos, perversos y perturbadores. La rica tonalidad de sus metáforas, sus imágenes enigmáticas y juegos de perspectivas y puntos de vista dan testimonio de su formación artística en las artes plásticas bajo la tutela de los maestros surrealistas Giorgio de Chirico y Fernand Leger. No se puede caracterizar su estilo como 
producto de su ambiente artístico y cultural. Todas las referencias a su relación con los miembros del grupo Sur no pueden dar cuenta de él dado que la proximidad no implica influencia. Las comparaciones y los contrates no hacen más que aportar otros elementos al análisis, pero se debe destacar que la obra de Ocampo amerita un acercamiento autónomo.

Podrá haber capítulos de la vida de la autora que permanezcan en la oscuridad para los biógrafos, pero sus obras literarias hablan por sí solas y constituyen un campo de estudio en continua expansión para los eruditos y académicos y una fuente de goce infinita, en la que se vierten dosis iguales de belleza y horror, para los lectores. Habida cuenta del cuidado que se debe tener para evitar el riesgo de caer en la trampa atractiva de analizar a la persona a través de su obra, en lugar de concentrar el análisis en la obra propiamente dicha, lo cual deriva en generalizaciones trilladas y presunciones sin fundamento, propongo un viaje exploratorio hacia la autora y la imagen que configuran sus obras y que se construye a partir de ellas: la de una artista dotada de una mirada aguda y de una voz distintiva, que se expresan a través del calidoscópico y siempre voluble hecho por lentes y espejos de ironía y distorsión. Sin duda, a partir de ese itinerario, se trata de un viaje de sumo atractivo.

Este viaje literario nos llevará por el corpus que supone la obra narrativa de Silvina Ocampo (1903-1993), la cual abarca cuentos y una novela producto de la principal cuentista mujer del siglo XX en las letras hispanoamericanas, una figura que, paradójicamente, permaneció en relativa oscuridad a pesar de una prolífica labor en poesía, narrativa, teatro y traducción literaria durante toda su vida. Hace poco tiempo, 
relativamente, que su obra ha recibido mayor atención crítica a partir de artículos académicos y disertaciones, si bien un estudio in toto aún está pendiente ${ }^{1}$. Tampoco han recibido suficiente atención las primeras reseñas y comentarios que aparecieran en su tiempo de parte de críticos, escritores y eruditos que gravitaban en su mismo círculo social, tales como, José Bianco, Jorge Luis Borges, Adolfo Bioy Casares, Enrique Pezzoni o Noemí Ulla, entre otros. Con su amigo Jorge Luis Borges y su esposo, Adolfo Bioy Casares, Ocampo co-editó una antología de relatos fantásticos y otra de poesía argentina pero este logro parece haber sido subestimado como si su contribución no hubiese sido en pie de igualdad (Klingenberg).

El propósito de esta disertación es examinar, reevaluar y reinterpretar la narrativa de Silvina Ocampo en el contexto de la literatura argentina. Al identificar sus principales rasgos -desde temas, recursos literarios, estructura narrativa, uso del lenguaje, etc.- $y$ evaluar su peso e interdependencia en la construcción de las historias, este estudio espera mostrar que su narrativa es una singular oeuvre d'auteur que marcó un hito importante no sólo en la literatura argentina, latinoamericana y femenina sino también en la evolución del cuento como género.

Tal como lo demuestra una serie de publicaciones recientes - dos libros y cinco disertaciones en las dos últimas décadas_ - los eruditos han comenzado a iluminar el abanico de posibilidades de análisis que se abre a partir de la obra de Ocampo. Hasta el momento, estos estudios se han enfocado en temas específicos: la niñez, la fantasía, la

\footnotetext{
${ }^{1}$ Me refiero aquí al estudio de todas las obras de Ocampo y hago la salvedad del estudio de Graciela Tomassini, El espejo de Cornelia, que se ocupa de pasar revista de los volúmenes de cuentos en una labor interpretativa a partir de los juegos de significación que involucran a un cuento y otro en cada volumen.
} 
representación femenina, la maternidad, la crueldad, el sujeto, entre otros. Si bien constituyen contribuciones valiosas e incisivas, sólo representan la punta del iceberg en relación con las áreas de la narrativa ocampiana que ameritan estudio e investigación. Al mismo tiempo, subrayan la necesidad de un estudio abarcador que pueda aunar los hilos principales que cruzan su obra dentro de un marco de referencia común.

Esta disertación se propone encarar una disección de la narrativa de Silvina Ocampo dentro de las amplias coordenadas que cruzan su obra: el fantástico, el surrealismo, el psicoanálisis y la literatura femenina, con el fin de caracterizar los rasgos distintivos y peculiares del estilo ocampeano y sus sensibilidades. Publicada en la época del psicoanálisis freudiano y su influencia en la estética surrealista, la narrativa de Ocampo es susceptible de ser objeto de un trabajo de análisis e interpretación desde este marco de referencia. El fantástico como género, con sus conexiones con lo onírico, el inconsciente, y lo irracional también encuentra articulación en la obra de Ocampo. A través de los datos biográficos, aun en su escasez, se espera completar la caracterización de su estilo. Si bien Ocampo no puede ser considerada una escritora feminista propiamente dicha (cuanto más cuando ella misma desdeña la etiqueta), una lectura de su obra desde la perspectiva feminista sacará a relucir otros aspectos de su estilo de los cuales no se podría dar cuenta de no ser desde la visión particular de una mujer escritora y su representación de la identidad femenina y sus relaciones.

El presente estudio busca demostrar que los recursos narrativos (narrador, ironía, ambigüedad, entre otros) abren “espacios de indeterminación”, una noción propuesta por las teorías de la recepción o reader response theories para designar las áreas del texto 
cuyo sentido debe suplir y completar el lector a fin de concretar el objeto estético. Éstas son, a su vez, responsables de los rasgos peculiares que los estudios identifican y subrayan en la obra de Ocampo: su capacidad para inquietar, intrigar, sorprender, es decir, para desestabilizar al lector. Es más, sirven para explicar las determinadas representaciones de la realidad que pueblan su narrativa; su interés en lo fantástico; la enunciación de lo anti-convencional como mecanismo subversivo para escapar del orden social dominante, que revela sensibilidades protofeministas.

En cuanto a la metodología, el punto de partida del estudio serán las lecturas profundas de una selección de cuentos recogidos en la compilación de sus Obras completas I y II (1999), que abarcan los once contarios publicados durante su vida. Al seleccionar obras de distintos períodos de su producción, se espera realizar un análisis diacrónico para obtener una caracterización redonda de su estilo. Al mismo tiempo, se realiza un análisis sincrónico de estos textos que incorpora datos históricos del contexto de producción y permite, a través de la comparación y el contraste, establecer un diálogo con otras obras literarias del período y evaluar las posibles influencias o contribuciones. Dicho análisis se efectúa desde el marco teórico y analítico de la crítica literaria.

El capítulo 1, “Silvina Ocampo y su tiempo”, ubica a la autora y su obra en tiempo y lugar, dentro del contexto de la literatura y en el área de estudios críticos sobre su obra. Trata los movimientos literarios que anteceden a su producción, las vanguardias, el surrealismo, y el grupo en torno a Sur, el círculo intelectual en el que se encontró Ocampo a raíz de sus lazos de familia y amistad. Presenta detalles biográficos que iluminan la lectura de sus obras y contribuyen a la interpretación de algunos textos: 
antecedentes familiares, viajes, estudios de música y pintura, labor como traductora literaria, entre otros. Examina, además, su colaboración en la antología de la literatura fantástica compilada con Borges y Bioy, hecho significativo que probablemente inició la línea de interpretación de su obra más prevalente e ineludible para bien o para mal² .

En el capítulo 2, “Modalidades de lo fantástico”, examino las particulares representaciones de la realidad que se configuran en la obra literaria de Ocampo y la inscriben como exponente del género fantástico. Las lecturas de "Viaje olvidado”, "El castigo” y “Los amantes” expondrán los mecanismos literarios empleados en su construcción. Luego, los analizo en relación con los postulados de lo fantástico que propone Tzvetan Todorov con el fin de obtener una caracterización matizada del género que se esboza en las historias de Ocampo.

El capítulo 3, "La exploración de los andamios de la identidad”, se enfoca en la intersección del psicoanálisis y la narrativa ocampeana. A partir de las lecturas de “La calle Sarandí”, "Voz en el teléfono” y “Cornelia frente al espejo”, se revela la manifestación literaria de varios postulados claves del psicoanálisis, tanto como elemento temático como marco teórico-crítico. Desde la fantasía (phantasy) hasta lo onírico, la sublimación, lo irracional, el subconsciente, la libre asociación -nociones de hondo arraigo en la estética surrealista tan cercana a la narrativa ocampeana — tienen cabida en ella a la vez que constituyen lentes de enfoque para su análisis.

\footnotetext{
${ }^{2}$ Desde su publicación, el intento de caracterizar genéricamente la obra de Ocampo ha discurrido a lo largo de la coordenada del relato fantástico, sin duda, reforzado por el hecho innegable de su compilación de relatos de este género en la Antología de la literatura fantástica (con una primera edición en 1940 y una segunda edición revisada y ampliada en 1965) junto a Borges y Bioy Casares. Si bien la obra de Ocampo incluye relatos fantásticos, se corre el riesgo de acotar y restringir el análisis a este campo y pasar por alto rasgos que ameritan otro acercamiento o caracterización.
} 
En el capítulo 4, "Silvina Ocampo y la escritura femenina”, propongo una lectura feminista de su narrativa. Me concentro en tres lecturas: "El vestido verde aceituna”, "El vestido de terciopelo" y “Las vestiduras peligrosas”, cuentos que, a partir del elemento común del vestido, permiten realizar un estudio del cuerpo femenino, tema privilegiado de la crítica feminista. Asimismo, abren la puerta a su visión de la identidad genérica y su rol como mujer escritora, sin forzar una postura feminista explícita que no existe: la articulación de lo que muchos críticos han identificado como una sutil pero penetrante crítica social ${ }^{3}$.

En la conclusión, se recogen los elementos principales del análisis con las hipótesis propuestas tendientes a caracterizar el estilo peculiar de la obra de Ocampo. A partir de lo expuesto, resulta evidente que el estilo de Silvina Ocampo resiste todo reduccionismo o caracterización simplista. Si bien exhibe elementos del movimiento surrealista y el género fantástico e incorpora nociones afines al discurso feminista, su obra no se conforma a ninguno sino que prefiere mantener la fluidez, la polifonía y la multiplicidad de sentidos de la opera aperta, y discurrir como verdadera écriture, más afín con las sensibilidades postmodernas y susceptible de continuar como objeto de estudio en el ámbito académico.

\footnotetext{
${ }^{3}$ En una entrevista con Noemí Ulla, Ocampo niega categóricamente ser "feminista” y comenta su rechazo de cualquier etiqueta. Sin embargo, es indudable que su penetrante mirada capta y transmite en sus obras con sutileza la problemática de desigualdad de la mujer en una sociedad patriarcal. No es casual que la mayoría de sus personajes sean mujeres. Más allá de este paso básico de representación textual, Ocampo despliega la temática femenina desde los márgenes socavando los roles tradicionalmente asignados a ellas a partir de una autodeterminación que les permite a sus personajes subvertir las expectativas sociales y convertirse en agentes activos.
} 


\section{CAPÍTULO 1 - Silvina Ocampo y su tiempo}

Escritora prolífica, Ocampo tiene publicados una docena de volúmenes de cuentos y poesía pero no gozó del reconocimiento de su obra por parte de la crítica y el público en general ${ }^{4}$. Quizás uno de los aspectos que representa el mayor obstáculo de este estudio no sea la obtención de fuentes de crítica literaria que versen sobre la obra de Silvina Ocampo sino de datos biográficos pertinentes que iluminen y enriquezcan el análisis de sus escritos. Se sabe que evitaba ser el centro de atención y que prefería la vida independiente y solitaria, casi de reclusión por lo que representa un desafío para los estudiosos que procuran rastrear en su biografía las claves, referencias y lecturas que se desprenden de sus obras. Como observa con acierto Patricia Klingenberg, Ocampo es "a woman who during her life succeeded in living almost invisibly among famous people” ("Notes” 111). Noemí Ulla también atestigua la dificultad que representa el proyecto de hacerle una entrevista: "Entendí que era una tarea imposible: un libro de entrevistas a una escritora que se negaba constantemente al asedio de las preguntas, a someterse al trabajo regular de una larga conversación”, (Invenciones 12)

Es el carácter esquivo, elusivo, del autor, el ocultarse deliberadamente, lo que sin duda despierta el interés de los eruditos por hacer las veces de detectives tras la pista de los motivos y las circunstancias de su “desaparición” en una búsqueda celosa y diligente. Resulta interesante que esta particularidad de la autora encuentra un paralelo en sus cuentos, en los cuales, la voz narrativa juega a las escondidas con el lector implícito, conclusión del análisis de la técnica narrativa que hace parte de la presente disertación. El

\footnotetext{
${ }^{4}$ Su primer libro de cuentos Viaje olvidado (1937) y el primero de poemas Espacios métricos (1942) al igual que varios posteriores ven primero una edición limitada a través del sello editorial Sur.
} 
narrador esquivo es uno de los elementos más interesantes del estilo de Silvina Ocampo, un elemento que la señala como pionera, precursora (aunque no expresamente reconocida) de la ficción experimental que irrumpiría hacia los años sesenta. "No soy sociable. Soy íntima...” respondió Ocampo al ser interpelada sobre su supuesta reclusión. La respuesta nos resulta más que reveladora no sólo acerca de rasgos de su presonalidad sino también de aspectos de su estética. La "intimidad", ese contacto cercano a través de la mirada y la voz, es lo que sus narradores le proponen al lector. En la intimidad del acto de lectura, el narrador ocampeano atrae al lector hacia sí, lo implica en la historia, ya sea que le guste o no, que esté de acuerdo o no, siquiera que se dé cuenta de ello o no, e independientemente de las consecuencias, como se verá a lo largo del presente estudio.

Puede argumentarse, con cierto grado de aceptación, que el conocimiento de determinados detalles biográficos sobre un autor no tiene peso relativo en el análisis literario de su obra, que éstos sólo sirven de meras acotaciones anecdóticas y que lo que realmente cuenta es la obra. Ésa parece ser la línea de razonamiento que comparte Ocampo y que la llevó a advertir "Mi vida no tiene nada que ver con lo que escribo.” Sin embargo, ninguna obra literaria ve la luz en un vacío. Como toda obra de arte, es producto del hombre o de la mujer y de sus respectivas circunstancias, bien sea que nazca de una manifestación de rechazo a ese entorno, o como expresión de impulsos creativos dominantes en su tiempo, siempre las percepciones, emociones o ideas involucradas en su génesis son motivo de interés. Es por ello que el relevamiento de la vida del autor puede iluminar el análisis de su obra. A pesar de la advertencia de Ocampo, mi análisis mostrará que la vida de la autora puede no tener que ver con lo que ella escribe pero sí en cómo lo

\footnotetext{
${ }^{5}$ En Ulla, Encuentros.
} 
escribe. Su escritura es el viaje de exploración de toda su vida, una labor que se nutre de las expresiones artísticas en las que se formó: pintura, música, literatura; de su educación privilegiada; de sus extensos viajes; elementos que dan cuenta de las marcas una estética y estilo tan suyos. En este punto me parece oportuno citar una observación que Mancini hace a propósito del cuento "La muñeca” y que proyecta sobre la autora para una lectura de su actitud creadora:

En la narrativa de Silvina Ocampo, por su parte, el ser que recibe el personaje de «La muñeca», signado por la carencia y el abandono, la autoriza a apropiarse no de las cosas, sino del tiempo y los actos de la vida de los que creen detentar el poder y, al mismo tiempo, ese «hacer» concreto del personaje -la adivinación- aporta a la escritura una matriz narrativa. Pero hay algo más que desestabiliza la lectura y, en cierto modo, afirma el eje del trabajo: en la primera edición del relato aparecida en la revista Sur -una versión que podría considerarse idéntica a la versión de «La muñeca»- el título es «Yo». Un cambio y un gesto deíctico que señalan, desplazan y enriquecen la narrativa de Silvina Ocampo. (77)

Atenta a las posibles objeciones que puede generar su extrapolación de actitudes del personaje a la persona del autor, a partir del cambio que señala en el título del cuento, Mancini aclara:

Lejos de pretender una lectura biográfica, los movimientos sugeridos fundan la hipótesis de que los materiales que constituyen los cuentos de Silvina Ocampo y, probablemente, también sus resoluciones, remiten a 
conflictos y tensiones sociales cribados por una mirada sutil e inquisitiva.

El arte, sugiere Georg Simmel, es «una totalidad autónoma» a partir de fragmentos fortuitos de realidad. (78)

La cita de Simmel, sin duda de fuerte filiación semiótica, me parece inmejorable para caracterizar la labor de Ocampo en sus invenciones del recuerdo.

Es posible que la renuencia de la autora a hablar de sí haya contribuido a un hecho que puede constatarse cada vez que se realiza una búsqueda biográfica acerca de ella: la preponderancia de referencias a terceros de su entorno como recurso natural para construir el perfil de la autora a partir de comentarios, escritos, impresiones de aquellos que la rodean. Cómo se explican si no las constantes referencias a "su hermana Victoria, fundadora de la revista Sur”, “esposa de Bioy Casares” y “amiga de Jorge Luis Borges”, omnipresentes muletillas en las primeras líneas de cada epígrafe biográfico que se le dedica. Pareciera que el antiguo adagio “Dime con quién andas y te diré quién eres” fuera el principio guía de este enfoque tan común. Véase, por ejemplo, la reseña biográfica que acompaña la edición de sus obras completas por Emecé (1999):

Silvina Ocampo (1903-1993) nació en Buenos Aires. Desde joven estudió dibujo y pintura; uno de sus maestros fue Giorgio De Chirico. Publicó por primera vez en 1937 (Viaje olvidado). En 1940 se casó con Adolfo Bioy Casares y ese mismo año compiló con éste y con Borges una Antología de la literatura fantástica. Sus poemas y cuentos aparecieron en la revista Sur que dirigía su hermana Victoria. 
Si bien no podemos negar que estos datos resultan interesantes como incidentales, no constituyen ni por asomo la caracterización de la autora. Es asimismo inconcebible que quienes no dudan en reproducir dichas fuentes no las acompañen del matiz de relatividad que ameritan, como si por virtud de la invocación de tales nombres “conocidos” lo dijeran todo. A pesar de las limitaciones que supone, aun críticos de renombre han caído en la trampa de este acercamiento a la hora de presentar a Silvina Ocampo, y, por lo expuesto, se evitará reptetir el error en el presente estudio en favor de una caracterización que brinde un perfil de la autora en diálogo con su obra. Mencionar las relaciones de amistad o parentesco que vinculan a Ocampo con grandes figuras es un despropósito pues se trata de una autora cuya obra se caracteriza por su singularidad, por no parecerse a la de nadie, y dichas referencias sólo pueden contribuir a entorpecer la mirada que exige su figura y su obra con enfoques reduccionistas o simplemente equivocados.

La estética que plantea Ocampo requiere un acercamiento excepcional construido a partir de coordenadas y elementos a su medida. En este sentido resulta reveladora la observación de Judith Podlubne en cuanto a su experiencia en el estudio de la producción ocampeana y el intento de aproximarse a ella a través de otra referencia infaltable en cualquier reseña biográfica, a saber, ser miembro del entorno de la revista Sur: Impulsada por la agitación y el desconcierto que me había suscitado la lectura de su primer libro y muchos de sus relatos posteriores, intenté pensar dónde residía la singularidad de su literatura. Propuse entonces una vía de aproximación inicial demasiado previsible, sin dudas, escolar y, en algunos aspectos, también desacertada: consideré necesario contrastar el efecto que provocaban sus relatos con los de los escritores con quienes a 
menudo se la emparentaba en el interior de la revista... un subgrupo liderado por Jorge Luis Borges y Adolfo Bioy Casares e integrado por Silvina Ocampo, José Bianco y Juan Rodolfo Wilcock, entre otros” (12). A partir del rescate que la atención de la crítica ha operado en la obra de Ocampo, es posible constatar la matización y reconfiguración de los datos que se consideran esenciales para una breve reseña biográfica. Testimonio de ello es el fragmento que acompaña la edición póstuma de la novela La promesa (2010): Silvina Ocampo (1903-1993) nació y murió en Buenos Aires. Durante su juventud estudió dibujo y pintura en París con Giorgio De Chirico y con Fernand Léger. Hacia 1935, luego de conocer a Adolfo Bioy Casares, con quien se casó en 1940, se dedicó por entero a la literatura. Vivir rodeada de figuras imponentes, su marido Bioy Casares, su hermana Victoria, su amigo Jorge Luis Borges no le impidió cultivar una desafiante singularidad. Como lo prueba la enorme cantidad de obras inéditas que dejó al morir, su vida tuvo una pasión dominante: la escritura. (énfasis mío)

En contraste, en la edición a cargo de Ernesto Montequin, la referencia se repite pero esta vez se hace la comparación de antemano.

La mención de Victoria Ocampo corresponde hacerla en el contexto de la recepción crítica de la primera obra publicada por Silvina. Victoria, quien por entonces fungía como directora de la revista y editorial Sur, escribió la primera reseña crítica de Viaje olvidado, una colección de cuentos que apareció en el año 1940 bajo dicho sello editorial. La reseña comunica una mezcla de sorpresa y de dudoso elogio: sorpresa ante la 
incursión en la escritura por parte de otro miembro de la familia, un camino que ella misma había abierto como vehículo de auto-expresión. Señala el mérito de determinadas expresiones pero declara que el estilo no es de su gusto. El texto de la reseña es interesante pues Victoria asume la posición de autoridad que le dan los años que le lleva a su hermana menor, el hecho de ser su madrina de bautismo, circunstancia que utiliza para nombrarse madrina literaria, y además su editora. No pocos críticos han seguido los lineamientos de Victoria en su evaluación de la obra inicial, en primer lugar, por la autoridad que le reconocen a su opinión; en segundo lugar, por la originalidad del estilo y los temas, y la impronta sinestésica que le da el trasfondo de la experiencia de la autora en el ámbito de la plástica.

Borges escribe el prólogo al volumen Fait divers de la terre et du ciel y sus comentarios parecen por demás elogiosos. Tanto es así que podría argüirse que emanan del profundo vínculo de amistad que los une más que de la objetiva evaluación de un colega escritor. Al alabar la originalidad de su estilo, y en la detección de los temas tortuosos, crueles y extremos que prefiere la autora, Borges adopta un tono apologético: "Dans les récits de Silvina Ocampo il y a un trait que je ne suis pas encore parvenu à comprendre, c'est son étrange amour pour une certaine cruauté innocente ou oblique; j'attribue ce trait à l'intérêt, l'intérêt étonné, que le mal inspire á une âme noble”. Sin embargo, el peso del apellido que firma las líneas debe dar cuenta de los ecos que su opinión generó. Son abundantes las expresiones de concurrencia pero se pone en duda si nacen de un criterio independiente o de la ciega dependencia de la credibilidad que comanda una autoridad en la materia, por ser una figura de renombre en la literatura y por tratarse del amigo personal con un acceso privilegiado. Esta reseña es citada y reimpresa 
en artículos, reseñas, estudios, y notablemente en las solapas de la mayoría de las ediciones de sus libros — quizás como una estrategia de mercadotecnia del mundo editorial.

Todo esto, aunque admirable y seguramente bien intencionado, no serviría de mucho si la obra de la autora careciera de mérito propio. Si se remplazara el ya célebre apellido, si se eliminaran las referencias al esposo escritor, al célebre amigo, la lectura de la obra de Ocampo no dejaría de deslumbrar, capturar, intrigar y sorprender al lector, sea éste del campo académico o del público en general. Es ésa una constante de su producción, desde la poesía, el cuento, el teatro, la novela policial, el cuento infantil, la novela experimental. La autora tiene algo que decir y una manera particular de decirlo, y esa inventiva y estilo propios emergen en todas sus creaciones. El humor, a veces liviano, las más de las veces, negro, grotesco, es una de sus expresiones características. El habla popular, la sintaxis creativa, son recursos que utiliza con maestría para lograr el golpe de efecto. Lo que Victoria no supo ver en esas "frases atacadas de tortícolis" fue la mano diestra que a sabiendas buscaba alterar su forma para formar su propio código.

Silvina Ocampo nació en el seno de una familia ilustre y acomodada. La menor de seis hermanas, era trece años menor que Victoria. Siguiendo la tradición de las familias aristocráticas, las hermanas Ocampo, reciben una estricta educación en francés, inglés, historia, religión, álgebra y música a cargo de institutrices extranjeras. Sus primeras letras son en inglés y francés, mientras que el español ocupa un tercer lugar como lengua de estudio. A este hecho de su formación atribuye Silvina su lucha con la gramática española en el contexto de la creación literaria. A pesar de que esta opinión parece una admisión motivada por los comentarios de Victoria en su crítica a Viaje olvidado, en el 
marco de la crítica literaria se toma con cautela la reflexión del autor sobre su obra, interponiéndole la necesaria distancia literaria para obtener una lectura libre de sesgos inducidos. Por lo tanto, la confesión de Ocampo sobre su dificultad en el manejo del español podría leerse, en cambio, como una expresión de su constante perfeccionismo, hacia una búsqueda del giro preciso, de la expresión más acotada que refleje su espíritu creativo. De todos modos, es notable que, al entrar en el camino de la expresión literaria, optara por el español. Aunque Ocampo no aclara los motivos de su elección, puede especularse que el hecho de utilizar una tercera lengua como lengua de letras, propicia una constante vigilancia por parte de la autora, algo que la obliga a estar siempre en guardia y agudiza su mirada y su conciencia del proceso creativo. La correspondencia con José Bianco da testimonio del trabajo constante de revisión y reflexión al que se somete la autora.

\section{Espacios}

Es imposible hablar de la vida y obra de Silvina Ocampo sin detener la mirada en los espacios en los que se desarrolla. La mansión familiar en el centro de la ciudad, el solar de fin de semana en las afueras, la estancia en la pampa bonaerense, la casa de veraneo a orillas del mar, y su segundo hogar, Europa.

La mansión familiar aparece en diversas caracterizaciones en varias de sus historias. El lector recordará los amplios corredores, el ático, las dependencias del servicio que sirven de escenario a las narraciones, encuentran correlación en las descripciones de la casa paterna de la calle Viamonte, en el corazón de Buenos Aires, o la residencia de la calle Posadas en el elegante barrio de Recoleta. El poema "La casa natal" 
recorre esos espacios familiares que se reconocerán en las descripciones de varios cuentos.

La educación de Silvina transcurre en el entorno hogareño, que alterna entre la mansión de la ciudad y Villa Ocampo, la casa de veraneo ubicada en Beccar/San Isidro, en el Gran Buenos Aires, rodeada de amplios solares y jardines. Como es costumbre en las familias patricias de la época, su residencia también alterna por temporadas entre Buenos Aires y Europa, principalmente en Francia, por espacio de meses, si no, años. Ésa será una costumbre que acompañará a Ocampo el resto de su vida y un hecho que marcara su identidad como seres (y luego escritoras) cosmopolitas. Éste rasgo es más destacado en la personalidad de su hermana Victoria, quien, con toda naturalidad, asume el rol de nexo entre la cultura del viejo continente y la Argentina.

Es en París, hacia finales de la década del veinte, que Silvina perfecciona su formación en artes plásticas, estudiando con el maestro surrealista, Giorgio de Chirico. Ocampo recuerda, sin embargo, que el maestro estaba más interesado en practicar el psicoanálisis con su alumna. Si bien no era infrecuente que las familias de la élite argentina enviaran a sus hijos a París para completar su educación, en una especie de bautismo o rito de paso, la costumbre comprendía a los “señoritos”, no a las mujeres. Silvina Ocampo le debe la oportunidad de hacerlo a los esfuerzos de Victoria, quien apeló y convenció a su padre. Como pueden testimoniarlo familiares y amigos, la hermana mayor abrió el camino para romper el molde y las convenciones sociales de lo que una mujer podía hacer (Victoria consternó a su círculo al convertirse en la primera mujer en conducir un automóvil). Fue así que, acompañada por una chaperona, Silvina partió con destino a París, donde también estudió con Fernand Léger. 
La pintura fue una de sus primeras expresiones artísticas. Su primer dibujo publicado fue una contribución a la revista cultural Martín Fierro, que, por coincidencia, ilustraba el cuento del escritor argentino que se convertiría en su amigo y colaborador: Jorge Luis Borges. Cuando Ocampo conoce a Bioy Casares en 1934, es presentada como pintora. Rememorando el encuentro, Bioy relata que Silvina lo invitó a su atelier, ubicado en el piso superior de la mansión familiar. Según Bioy, ese encuentro se produjo por la insistencia de su madre: “debía conocer a Silvina” ... "porque es la más inteligente de las Ocampo”. Este comentario es otro de los tópicos de su biografía.

Otro lugar que reviste gran significación en la obra de Ocampo y en su desarrollo artístico como escritora es el campo argentino. Su familia era propietaria de estancias en la provincia de Buenos Aires. También era el caso de su compañero y luego esposo, Bioy Casares, a cuya estancia, Rincón Viejo, se trasladan al poco tiempo de conocerse y eligen como primera residencia. Años más tarde, contraerán matrimonio en el vecino pueblo de Pardo con Borges como uno de los testigos. Es allí donde Silvina comienza a escribir. Las circunstancias y los motivos que la llevaron a hacerlo quedan en el reino de la ficción biográfica. En sus memorias, Bioy declara en forma escueta que al regresar de Europa, Silvina abandonó la pintura para dedicarse a escribir. En otras versiones de la "fábula de los orígenes”, se presenta a Bioy como el impulsor de ese nuevo vehículo de expresión artística. Los datos más fehacientes corresponden a los manuscritos de sus primeras obras que fueron fechados en Rincón Viejo.

Fuera del aspecto anecdótico como locus de la génesis de la escritora, el campo figura como espacio de la acción en varias historias. Sin caer en el costumbrismo, Ocampo sabe presentar los elementos descriptivos esenciales que dan vida a los relatos y 
les infunden el aire de verosimilitud justo según los requisitos de la trama. Su familiaridad con la gente, el quehacer, la flora, los animales, la topografía y demás pormenores se deben tanto a su fascinación por ese ambiente natural como a las largas temporadas pasadas allí.

El mar también ejerce una poderosa fascinación e influencia en la autora. Son numerosos los poemas que le inspira y los cuentos que lo tienen como elemento dominante y significativo. Típicamente visto como un lugar de descanso y tranquilidad, a veces se torna una imagen ambivalente que cita como fuente de inspiración u obstáculo para su escritura, por convertirse en una potente distracción. En correspondencia con José Bianco, su editor y colega, a menudo menciona al mar como culpable de su imposibilidad de escribir una frase entera, de redondear una idea. ${ }^{6}$ Creyendo siempre que apartarse a este lugar de descanso propiciará una mejor oportunidad para escribir, Ocampo comprueba lo opuesto, que le resulta imposible pretender ajustarse a un régimen disciplinado de redacción.

\section{Escritura}

No hay reseñas biográficas que versen sobre el proceso que llevó a Silvina Ocampo a la escritura ${ }^{7}$. La mayoría de las fuentes simplemente se limitan a dar como dato que "La siesta en el cedro" su primer cuento publicado en la revista Sur, aparece en 1936. En una entrevista, Ocampo comenta que conoció a Bioy al tiempo que comenzó a

\footnotetext{
${ }^{6}$ José Bianco Papers, Manuscripts Division, Department of Rare Books and Special Collections, Princeton University Library. Cit. en Klingenberg “A Life in Letters”.

${ }^{7}$ Se ha dado poca difusión a las contadas entrevistas que dio la autora. Este hecho es una falta grave cuando se trata de la crítica. Una de las omisiones más patentes es la poca atención que se la dado a la entrevista de Adela Grondona, “¿Por qué escribimos?” realizada en 1969, donde Ocampo consigna experiencias y opiniones acerca del proceso de la escritura. Agradezco a la Prof. Adriana Mancini por el préstamo de este artículo.
} 
escribir, que Bioy y la escritura aparecieron en su vida prácticamente al mismo tiempo. Este comentario en el que se reconoce un dejo de ironía pasará a integrar el elenco de tópicos sobre su vida y su obra. En algunos casos, la deformación de la anécdota llegará a reordenar los factores en una relación de causa y efecto: la llegada de Bioy a su vida la impulsa a escribir. ${ }^{8}$

Un año después, su primera colección de cuentos Viaje olvidado es publicada bajo el sello editorial Sur. Además de la reseña de Victoria, el hecho de que Silvina escriba resulta sorprendente para miembros de la familia y de su círculo. Más que ilustrar el proceso creativo, el comentario revela el prejuicio de la sociedad del momento, en lo que es aceptado o no dentro de la concepción de la tradicional división de roles. La imagen de Silvina como un ser independiente, poco convencional, se afirma a partir de su incursión en un ámbito que típicamente estaba reservado al hombre según el pensamiento de entonces.

Ocampo se aboca a la escritura, de la que hará un camino de trabajo constante, alternando poesía y prosa, así como la labor de traducción literaria. Su editor Ernesto Montequin da testimonio de que continuó escribiendo hasta poco antes de su muerte. El reconocimiento de su mérito como cuentista y poeta vino a través de varios premios literarios durante su carrera. Sin embargo, su producción no se limita a lo que se llegó a publicar en vida. En años recientes, se han editado varios tomos póstumos a partir de un

\footnotetext{
${ }^{8}$ En notas periodísticas o en reseñas sobre sus libros se suele citar el pasaje de las memorias de Bioy Casares: "En el Rincón Viejo, Silvina se alejó paulatinamente del dibujo y de la pintura y se puso a escribir" (Memorias 87). Ver también los comentarios de Patricia Klingenberg sobre su entrevista con Ocampo en "A Life in Letters". Ver el artículo de Hugo Beccacece "La gracia y la malicia, unidas en un matrimonio fascinante" que reproduce una entrevista que la revista "Claudia" le hizo a Bioy y Ocampo en 1983.
} 
caudal de manuscritos que dejó, tanto de poesía como de prosa. Este acontecimiento editorial, que coincide con fechas conmemorativas, sumado a los esfuerzos de la crítica literaria, parecen haber facilitado por fin el reconocimiento y la atención que su obra merece y hacerlos extensivos a nuevos ámbitos, incluso el del público lector en general. Valenti observa con precisión que los dos últimos volúmenes de cuentos, Y así sucesivamente y Cornelia frente al espejo:

nos muestran que es imposible seguir concibiendo el cuento como un universo completo, cerrado, acabado; nos obliga nosotros, lectores, a replantearnos tantas verdades que se dan por descontadas, sobre todo en lo que respecta a la unidad funcional constituida por la historia y el discurso, una de las principales normas del género. (447-8)

Valenti denomina “encanto” la poderosa atracción que surge de los cuentos de Silvina Ocampo y atribuye su fuente a:

la singular combinación de penetración psicológica, sutileza y refinamiento semántico y pulido formal que los caracteriza. En este aspecto la impronta de la fuerte personalidad de la autora incide en la esfumatura de los límites genéricos en estos textos que, aunque los reconocemos como cuentos, escapan a las características estrictas del canon y nos planteamos ¿es prosa poética? ¿es poesía narrativa? o ¿̇son textos que por la misma libertad que ha alcanzado la autora con la madurez de su oficio literario, exceden las clasificaciones habituales? 
Siguiendo la línea de pensamiento que Valenti traza en la evolución del estilo ocampeano, para la autora es en Autobiografía de Irene donde Ocampo despliega ya otra característica que será identificatoria de la narrativa de nuestra autora: una oscilación permanente entre la nostalgia y la sátira, entre lo poético y la ironía, entre la "literatura" y los tópicos, oscilación que confiere un perfil vigorosamente original a su producción y que nos permite afirmar que abre nuevos horizontes al cuento como género textual. En esa apertura hay que computar también las características recurrencias en la diégesis y en el discurso y ciertas incorporaciones digresivas que obliteran la tradicional exigencia de síntesis y despojamiento del cuento como género. (447)

Un ejemplo de estas incorporaciones digresivas puede verse en su máxima expresión en el cuento "Cornelia frente al espejo" y en su doble teatral "El espejo ardiente” donde aparecen digresiones eruditas acerca de la historia del espejo y del sombrero, además de fragmentos sin ilación que parecen cuadros del teatro del absurdo.

Obras en colaboración y dispersas

Además de su obra individual, Ocampo realizó colaboraciones literarias. En 1941, sale a la luz su primera obra en colaboración, la Antología de la literatura fantástica, una colección de cuentos preparada con Jorge Luis Borges y Adolfo Bioy Casares. El prefacio, firmado por Bioy, está fechado en 1940 en Rincón Viejo y versa sobre la génesis y el criterio ordenador a la vez que lanza una crítica a la novela psicológica, 
subgénero narrativo que encuentran deplorable ${ }^{9}$. El volumen fue reeditado en 1965 e incluyó una posdata de Bioy en la que si no desdice algunos de los comentarios originales, sí los matiza con el beneficio de la retrospectiva. El volumen contribuyó a cimentar la lectura de los cuentos de Ocampo desde la literatura fantástica, punto que abordaremos en el capítulo 2.

En 1946, se publica Los que aman odian, la única ${ }^{10}$ incursión de Ocampo en la novela detectivesca, escrita en colaboración con Bioy. En sus memorias, Bioy deja testimonio del placer de colaborar con Silvina. Sin embargo, el experimento no volvió a repetirse a juzgar, al menos, por el corpus de publicaciones.

Con Juan Rodolfo Wilcock, Ocampo escribe Los traidores (1956). Se trata de una obra de teatro en verso. Como en el caso de la Antología, la colaboración en el plano literario parte del vínculo afectivo. Sin embargo, a diferencia de aquélla, se le suma una mayor afinidad de gustos y planteamientos estéticos. ${ }^{11}$

Otra obra de teatro titulada La lluvia de fuego fue realizada con otro amigo, Juan José Hernández, probablemente hacia mediados de la década del sesenta. Sin embargo, el primer testimonio de este hallazgo llega con la noticia de la puesta en escena en París, en el año 1997, de La pluie de feu, por parte de la actriz argentina radicada en Francia, Marilú Marini. En un artículo, cuyo propósito es reivindicar su participación, Hernández

\footnotetext{
${ }^{9}$ El contexto de esta afirmación se basa en la polémica Borges-Mallea sobre el futuro de la novela. Para un análisis pormenorizado de este asunto y sus ramificaciones en el contexto literario argentino, ver el artículo de Podlubne "Borges contra Ortega” y el capítulo pertinente de la misma autora en Escritores de Sur.

${ }^{10}$ Esto es, si exceptuamos “El impostor” que más que cuento ha sido calificado como novela corta y que admite como una de sus lecturas válidas, la del relato policial.

${ }^{11}$ Son Bioy y Silvina quienes llevan a Wilcock en uno de sus viajes a Europa, el primero para este último, en el año 1951. Allí permanecieron unos 8 meses, principalmente en Italia y Francia. Tiempo después, Wilcock se radicará definitivamente en Italia y publicará también en italiano.
} 
refiere que con ocasión de una cena en casa de Silvina y Bioy, en la que estaban presentes Manuel Peyrou y Borges, este último preguntó por la obra que Ocampo y Hernández estaban escribiendo “en secreto”. Silvina por superstición se negó a dar pormenores del argumento y sólo reveló el título, el cual Borges consideró una alusión a la obra de Lugones. Silvina le aclaró con humor: “Te equivocas, Georgie. No tiene nada que ver con la destrucción de Sodoma y Gomorra de la historia de Lugones. La lluvia de fuego es una inocente begonia que adorna los jardines de Tucumán” (lugar de nacimiento de Hernández). Según refiere Marilú Marini, el manuscrito inédito de La lluvia de fuego, se lo entregó Bioy como regalo. Hernández especula generosamente que Bioy no debe haberlo leído y que sin advertirlo omitió su nombre como co-autor. A pesar de que no medió aclaración por parte de Bioy o de su entorno sobre este hecho de carácter polémico, sirve como indicio de que el universo de la producción ocampeana trasciende las páginas editadas.

Uno de los volúmenes de Ocampo más celebrados, Autobiografía de Irene aparece en 1948. Consiste en novelas cortas más que cuentos de las que se destacan el texto que da título al volumen y “El impostor”. Este último, fue adaptado a guion cinematográfico por Maria Luisa Bemberg (y la participación de Ricardo Piglia), pero debido a su salud, no pudo dirigirla (tarea que emprendió Alejandro Maci y completó en 1995). Esta colección, que aparece 11 años después de Viaje olvidado, exhibe un marcado contraste con la inventiva y singularidad del primer volumen. Para un estudio de la relectura que merece resultó esclarecedor el estudio de Judith Podlubne, Escritores de Sur: Los inicios literarios de José Bianco y Silvina Ocampo, en el cual traza las diferencias de recepción entre uno y otro volumen a partir del debate literario entre dos 
corrientes distintas en el seno de la revista. Autobiografía es vista como una desviación del camino que inaugura Viaje olvidado en favor de un experimento de carácter más formalista en consonancia con los preceptos de Borges y Bioy sobre lo que debe ser la literatura. El impulso singular y transgresor que ya no la abandonará, regresa con renovado ímpetu en La furia y otros cuentos y caracteriza toda su producción posterior.

Invenciones del recuerdo (2006) es una autobiografía en verso publicada póstumamente. El texto resulta problemático para el entorno de Ocampo, pues puede leerse como un poema à clef, como lo han señalado Noemí Ulla y María Teresa Vázquez. A pesar de que los nombres y los pormenores han sido alterados en el proceso creativo, es posible trazar las referencias a las personas y los hechos que se narran. Este hecho fue apuntado por la propia Ocampo en distintas ocasiones, como en la entrevista de Adela Grondona en ¿Por qué escribimos? Las implicaciones de este hecho literario incluyen un cambio en la mirada de su obra precedente, propiciando una relectura de los elementos autobiográficos. Cabe acotar que no estamos hablando de una lectura sino de una de tantas posibles, pero que por contar con la sanción autorial, resulta más difícil de soslayar. En la nota del editor que la acompaña, se resalta, quizás en anticipación de los horizontes de relectura que plantea, que Invenciones permite capturar las primeras experiencias de percepción de Ocampo como escritora que dieron forma a su visión y a su arte. Quizás la lectura más importante desde mi punto de vista sea la de un ejercicio de reconstrucción de la memoria del sujeto como formadora de la identidad y de la construcción del sujeto a partir de la memoria, por un lado, y el rol de la memoria y su contraparte, el olvido, en cuanto proceso creativo, por el otro. 
A propósito del elemento autobiográfico en sus obras, varios críticos han señalado la posible correlación de ellos con el material literario. Noemí Ulla apunta a la fuerza de la primera persona de la enunciación para evocar la asociación de la voz narrativa con el autor. Esta impresión es reforzada por la frecuencia con la que la autora emplea este encuadre en determinadas formas narrativas, la carta, el diario, la "confesión”, por cuyo uso Ocampo sienta un importante precedente en la literatura rioplatense.

La carta, el diario, son géneros que tienen uso frecuente en Silvina Ocampo. Una y otro permiten la utilización de la primera persona que crea al lector cierta expectativa frente a lo autobiográfico, ofreciéndole al autor otra ilusión: la de enmascararse. Detrás de la voz esa primera persona, sin desdoblamiento, el escritor se constituye en una de las tantas dispersiones de su identidad. Por ella, consigue travestirse y abarcar zonas de lo real que parecen distantes sin la exhibición del simulacro. Esto permite a la autora jugar con el sexo del sujeto de la enunciación: tan pronto es un hombre, tan pronto una mujer. La aventura que inicia el discurso autobiográfico hace suponer a quien lee que siendo una mujer la autora del cuento, lo es también el sujeto de la enunciación, pero muchas veces surge el equívoco, ella se emboza o se muestra, y después de que hemos transitado suficientemente su narrativa, estamos como alertas ante la sonrisa que descubre al sujeto masculino o femenino. (Invenciones 53) En esta explicación se ven los puntos de partida para el estudio del estilo ocampeano: la importancia del lector, el enmascaramiento de la voz narrativa, el 
juego de dobles del autor implícito y el autor empírico, la mirada sobre el objeto que oscila entre encubrir y mostrar.

El corpus de las obras de Ocampo incluye otra novela La torre sin fin, registrada como de edición póstuma en 2007. Sin embargo, la reseña editorial acota que fue publicada en vida de la autora pero casi "secretamente” en España, en 1986, hecho que era desconocido en Argentina.

\section{Labor como traductora - Revista Sur}

La labor de Ocampo como traductora literaria se desarrolló en el contexto de Sur. Esta revista de cultura y sello editorial fue la fuente de las traducciones consagradas de obras extranjeras de ficción, ensayo, poesía, teatro y crítica. El primer número de Sur apareció en 1931. Fundada y dirigida en un principio por Victoria Ocampo, contaba con una junta editorial estelar, si bien de tradiciones y estéticas dispares: Jorge Luis Borges, Eduardo J. Bullrich, Oliverio Girondo, Alfredo González Garaño, Eduardo Mallea, María Rosa Oliver y Guillermo de Torre de Argentina, Waldo Frank, Ernest Ansermet, Pedro Henríquez Ureña, Alfonso Reyes, José Ortega y Gasset, de Europa, por nombrar algunos. "La sobresaliente figura de su dueña y directora [Victoria Ocampo] opacó la del grupo que la sustentaba.” (Prieto, 277) El hecho de que su directora fuera una mujer y, además, rica, provocó que la revista fuese vista, en un primer momento, más como la realización de su deseo personal que como el producto de la necesidad de un grupo, lo que la convirtió por mucho tiempo en objeto de críticas -sobre todo ideológicas y políticasque por contigüidad se desplazaron hacia sus colaboradores más inmediatos. Esta actitud, sin embargo, pasaba por alto un hecho que hoy resulta evidente, y es que entre los años 
1931 y fines de la década cuarenta, más allá de sus declarados fundamentos que atendían al plano cultural amplio más que al literario, Sur no sólo concentró algunos de los debates más interesantes sobre literatura argentina sino, también, como señala María Teresa Gramuglio, “ocupó una posición dominante en el campo literario, sustentada en el sólido entramado que se configuró entre la literatura, la crítica y las traducciones publicadas en la revista y ese suplemento insoslayable que fue la editorial Sur".

En cuanto a las traducciones, basta con consultar el índice de los primeros 20 años dela revista para corroborar

el enorme valor de los autores introducidos o difundidos por Sur-la revista y la editorial—a los lectores argentinos como Virginia Woolf, André Gide, Graham Greene, T.S. Eliot, Wallace Stevens, William Faulkner, Herny James, entre muchísimos otros. Pero también, como lo ha demostrado Patricia Willson, el valor de las mismas traducciones, consideradas ejemplares o canónicas en el extenso territorio de la lengua española, fueran éstas realizadas por traductores netos... o por traductores que además eran escritores, adquiriendo su trabajo, en este segundo caso, un valor agregado por el modo positivo como funcionaron en la construcción de la propia obra de cada uno de ellos. (sp)

A partir de esta contextualización se puede valorar la labor de traducción que llevó a cabo Silvina con la poesía de Emily Dickinson. Se ha señalado que el estilo particular que aportó Ocampo contribuyó a que los lectores en español pudieran disfrutar de las sutilezas del imaginario de Dickinson y el ritmo de su voz. Para Silvina Ocampo “traducir significaba no sólo asumir otra lengua sino 
también, y sobre todo, otro sujeto” explica Aguirre. "Había que ‘meterse en el otro’, y esa condición se radicalizó en el caso de Dickinson: “Traduje a otros poetas, pero no tienen ese juego con las frases y las ideas que se van trenzando y que uno tiene que descifrar” (sp).

A pesar de su colaboración en Sur y su pertenencia a ese círculo, Podlubne explica:

La relación de Silvina Ocampo con el grupo Sur se ha planteado más desde su posición que por una estricta afinidad literaria con sus integrantes. Claro está que de su labor como colaboradora de la revista hay sobradas pruebas: es en Sur donde se publican sus primeros cuentos y poemas, como “Viaje olvidado” de 1937; y para este medio realiza trabajos de traducción literaria, entre ellos la versión en español de la poesía de Emily Dickinson. La obra de Ocampo tiene poco que ver con la de Victoria Ocampo, Borges o Bioy Casares, personas que por parentesco y amistad están cerca de ella, en su círculo íntimo. En cambio, sus filiaciones literarias no sólo trascienden ese círculo sino que presentan un signo de independencia y autonomía. Puede decirse que su estilo se nutre de una variedad de fuentes y lecturas predilectas, desde mitología (griega, oriental, indígena), los clásicos europeos, la literatura de vanguardia, en particular el surrealismo, sin descontar la influencia de otras artes como el dibujo, la pintura y la música. Más cerca de Kafka, de Cortázar, de Juan Rodolfo Wilcock. (sp) 
La infancia en la obra de Ocampo

Un estudio comparativo de la infancia en las obras de Silvina Ocampo, Nora Lange y Elena Garro, realizado por López-Luaces, caracteriza a las obras de Ocampo como configuradoras de un universo de opuestos, en el cual los niños se comportan como adultos desestabilizando y subvirtiendo el equilibrio del poder y las estructuras tradicionales dadas. Este universo alternativo que Ocampo crea a través de su ficción se presenta como el c'est que dois être, lo que debe ser, y abre la puerta de escape de los límites que impone la sociedad. ${ }^{12}$

El mundo infantil que emana de los cuentos de Ocampo es un ambiente hostil para el niño, sin importar cuál fuere su posición social. La casa que se supone debe ofrecer abrigo, protección, no es un lugar seguro. El peligro acecha al niño solitario que crece en un mundo de adultos demasiado distantes para tenerlos en cuenta o para ocuparse de ellos. Los niños deben abrirse paso, librados a su propia suerte, con resultados diversos. En algunos casos, el lado más oscuro del espectro les depara la muerte. En otros, aquellos que escapan, quedan con cicatrices perennes. A fin de cuentas, el mundo es un lugar hostil y nadie queda exento.

Uno de los temas que trabaja Ocampo en relación con la niñez es la pérdida de la inocencia. No se trata una literatura de iniciación o “coming of age” en el sentido estricto sino de una revelación, del paso del yo del imaginario al ámbito simbólico, que supone

\footnotetext{
${ }^{12}$ López-Luaces, Marta. Ese extraño territorio: La representación de la infancia en tres escritoras latinoamericanas. Santiago, Chile: Cuarto Propio, 2001. La tesis doctoral de la misma autora: Ese extraño territorio: La representación de la infancia en 'Cuadernos de infancia' de Norah Lange, 'Las invitadas, ' 'Las noches de los dias' y 'La furia' de Silvina Ocampo y 'La semana de colores' de Elena Garro. Dissertation Abstracts International, Section A: The Humanities and Social Sciences, 60:2 (1999 Aug) La obra también está disponible en inglés: López-Luaces, Marta and Lea Fletcher. That Strange Territory: The Representation of Childhood in Texts of Three Latin American Women Writers. Estudios de Literatura Latinmoamericana. 6. Newark, DE: Cuesta, 2004. Pionero en este idioma es el estudio de Fiona Mcintosh
} 
siempre una pérdida. Los casos sobresalientes tienen que ver con la iniciación sexual que, en la mayoría de los casos, es de carácter traumático. En “Las invitadas” la iniciación se aborda desde la modalidad del fantástico mientras que, en “El pecado mortal” , a partir de una exploración metacognitiva y, en “La calle Sarandí”, a través de una narración estilizada con rasgos líricos.

En otras historias, los niños se convierten en agentes desestabilizadores para los adultos. Así, se dan casos en los que llevan a cabo su venganza bajo la apariencia de un accidente, cometiendo un crimen que queda impune. En el universo narrativo ocampeano, parece ser una operación de cierta justicia poética a la vez que un intento de provocar y poner el mundo al revés. Lo que no se da en la realidad, encuentra una vía de actualización en sus páginas, en una especie de experiencia catártica. A veces, puede revestir un carácter sutil, otras, contundente pero el efecto es innegable. Con un toque magistral, de prestidigitador, la autora pone los tantos en orden, altera el curso de la historia en el universo paralelo de la ficción. La fabulación se presenta como una salida, una vía de escape, como es el caso de los personajes de Tales eran sus rostros, los niños sordomudos a quienes les salen alas y esquivan a la muerte. Otros no corren la misma suerte, como ocurre en "La soga”.

La crítica ha abordado el locus de la infancia en la narrativa de Ocampo desde diversos acercamientos. Los estudios específicos de este tema realizados por Mackintosh, Bermúdez-Arceo, López-Luaces, Astutti, de alto valor, se centran en la cuentística y la poesía édita. Sería pertinente para una reevaluación del mundo de la infancia en la obra de Ocampo, una relectura a partir de Invenciones del recuerdo en diálogo con su producción anterior. 
La propia Ocampo destaca lo importante de ese momento de la vida al designarlo como la inspiración y el motivo de su escritura. En una de las pocas entrevistas que concedió, Adela Grondona le pregunta: “Alguien se me adelantó a preguntarle qué la impulsó a escribir y usted contestó entre otras cosas: “Una imagen indescifrable, que perdura, de la infancia”. (175) Ocampo responde:

Creo que los recuerdos más importantes, más fáciles de contar, más poéticos, más para siempre, son los de la infancia. Quitárselos a la literatura sería como quitar la esencia de la vida. Con el tiempo, huérfanos inconsolables, ya que todos somos, la infancia se vuelve nuestra madre. (énfasis original 175)

\section{La literatura (escritura) como exorcismo}

El mundo de la ficción permite remediar las contradicciones e injusticias del mundo real. La ficción y la fantasía, al contar con reglas propias, se prestan para un efecto de control que permite hacer justicia a través de premios y castigos para restaurar o instaurar un equilibrio. Esta mecánica básica, en el plano de la ejecución, adquiere un grado de complejidad a partir de un juego de marchas y contramarchas, de giros y contragiros. A veces, quien lleva las de perder es el lector (entendido, claro está, como el lector implícito). Los hilos de la ficción conducen al lector por el laberinto pero a diferencia del mítico episodio, en ocasiones es abandonado a su propia suerte. A través de un juego de seducción y abandono, el autor establece las pautas para dar el golpe de efecto. No existe el lector pasivo en la obra de Ocampo. El lector se vuelve cómplice, testigo, perpetrador o víctima, pero nunca es inocente, impasible. El acto de lectura lo 
convierte en parte activa del juego. Más tarde, Cortázar definiría enfáticamente al lector que requería su literatura, condenando al lector burgués, pasivo y consumista. Sin teorizar al respecto, Ocampo ya configuraba un planteamiento similar a partir del primer volumen de cuentos. La obra de Ocampo es una lectura fascinante, pero a esa fascinación está unido el horror. Lo abyecto de la sociedad y el ser humano aparece desde el eje temático o recursivo pero no desde un propósito moralizador. Se trata, tan sólo de despertar al lector, de sacudirlo de su comodidad, de presentar lo que no quiere ver, de que escuche lo que no quiere oír a menudo en el tono o el registro del habla que denigra y en boca de “personajes” muy distantes de su entorno.

Ocampo escribe sobre lo que conoce mejor pero, a través de su lente, las imágenes distorsionadas, las antípodas, sirven para denunciar las fallas y las locuras de una clase corrompida que se viste de pureza y corrección la proverbial manzana podrida de apariencia lustrosa. En “La música de la lluvia” (Y así sucesivamente, 1987), un concierto de piano, pasatiempo común de la élite burguesa, se transfigura con elementos del absurdo.

No resulta sorprendente que su obra no gozara de la popularidad que tuvieron las de sus contemporáneos. Su ficción se erige como un espejo pero un espejo infiel, no el de Stendhal sino al estilo de los espejos deformadores de las casas de juegos (más afines a los famosos espejos de Valle Inclán). La imagen que devuelven es aberrante pero tan certera que es imposible no admitir su justicia. Es una imagen difícil de enfrentar. Las imágenes distorsionadas, sin embargo, representan la esencia que subyace en el objetosujeto que se le pone delante, con lo cual, la ficción ocampeana hace las veces del retrato de Dorian Grey aunque, a diferencia de éste, la imagen que se marchita y se descompone 
a causa de los excesos no está oculta sino en exhibición. La obra de Silvina Ocampo sirve como exorcismo de los demonios de la oligarquía argentina. Sus cuentos, sobre todo, capturan lo reprochable, lo abyecto y lo ponen sobre el tapete.

La voz autorial sanciona claro está, desde los márgenes de su propia clase, hecho que no mitiga su mordacidad sino que la exacerba pues ese lugar liminal le permite hablar con pleno conocimiento del mal que se esconde bajo el barniz del lujo y los privilegios de clase. Entendemos marginal no en sentido que reviste el término tradicionalmente, es decir, en los márgenes de la sociedad a partir de un concepto socioeconómico, sino marginal en cuanto al posicionamiento dentro del grupo al que pertenece. Vale la aclaración pues algunos sectores de la crítica no la encuentran lo suficientemente "marginal” por el hecho de tratarse de una escritora proveniente de un sector privilegiado. Al ubicarse en el margen como lugar de enunciación, Ocampo puede aplicar su mirada aguda hacia ambos lados del espectro: tanto a la élite como a la clase trabajadora. A partir de su minuciosa caracterización, estos últimos son perfectamente reconocibles. Merece particular atención su logro en materia del habla, a partir de un perfecto manejo de los registros y los coloquialismos del habla popular.

Al abrir las compuertas al acervo lingüístico de la cultura popular que es marca de clase, Ocampo ensancha el espacio narrativo para albergar a personajes de la clase popular que no tenían voz ni representación en dicho espacio. Ocampo los invita a pasar, a no quedarse afuera. Una vez que pisan el escenario, que salen a escena, ya no hay vuelta atrás. Los invitados toman luego posesión de la casa y conviven con los dueños, o mejor dicho, los inquilinos originales, transformando el espacio en una sede del 
Carnaval $^{13}$. Las ramificaciones de la inclusión del personaje popular (modistas, costureras, sirvientas, institutrices, maestras, adivinas, vendedoras, peones, etc.) dan cuenta de un uso que se aparta de la práctica tradicional de presentarlos como mero telón de fondo o recurso de color local para darles el papel protagónico que define no sólo su estilo sino una corriente posterior en la narrativa argentina.

El humor es otra herramienta que Ocampo emplea para dar vida a los personajes en las páginas de ficción. El humor le brinda la libertad de decir aquello que no se puede decir, desde un lugar relativamente seguro. "Es una broma” sirve de paliativo para cualquier dardo que resulte demasiado agudo.

Ocampo y las letras femeninas

En Historia Crítica de la Literatura Argentina, Drucaroff señala una observación certera acerca de la recepción crítica de Silvina Ocampo: “En efecto, la crítica ignoró casi radicalmente, hasta finales de los años ochenta, la complejidad, el humor y la originalidad de Ocampo; le dedicó breves y condescendientes palabras que la clasificaron rápidamente como autora de literatura fantástica y obviaron, con cortesía, señalar los defectos que seguramente le encontraban”. (463)

En el análisis de Drucaroff, se ve a Ocampo tanto como una figura única en las letras argentinas que no tuvo herederos y, al mismo tiempo, como un referente para el

\footnotetext{
${ }^{13}$ El motivo del carnaval recorre la obra de Ocampo con el ritmo de la danse macabre y la inversión de roles y laxitud de restricciones de las saturnales. Bajtín define el Carnaval como un fenómeno por esencia polifónico: la percepción carnavalesca del mundo posee un extraordinario poder de regeneración y de transfiguración, una vitalidad inagotable. La restricción y la inversión del orden social. El carnaval elabora todo un lenguaje de formas simbólicas y concretas desde las grandes y complejas acciones de las masas. Este conjunto de ritos y festejos que tienen profundas raíces sociales, es un fenómeno interesante en la historia de la cultura, en la medida que se refleja en lo literario, pues permite ver cómo se establece una vez más la relación literatura-sociedad. De alguna manera, la carnavalización es el producto del diálogo del creador y la cultura popular pues el texto se sitúa en la historia y en la sociedad.
} 
estudio de las obras de escritoras mujeres en la ficción argentina de los años sesenta en adelante. El término "paradoja” nos parece apropiado para calificar esa apreciación sobre la autora pero desafortunadamente, Drucaroff no elabora sobre la naturaleza de esta paradoja como tampoco ofrece ejemplos que ilustren su punto: partiremos de ella para plantear en principio una paradoja: mientras la crítica ignoraba o no comprendía lo que escribía Ocampo, ella iba haciendo aparecer, despacio y probablemente sin proponérselo, una escritura que se constituía como un sólido linaje de búsquedas, obsesiones y recursos compositivos femeninos, una escritura que se volvería insoslayable para entender la producción de escritoras posteriores, porque propiciaría apropiaciones creativas y otorgaría legitimidad específica (hasta entonces inexistentes) a formas de composición narrativa que muchas escritoras —incluso sin conocer su obra fundadora—empezarían espontáneamente a buscar a partir de los años sesenta. (463) Drucaroff procede a realizar una aclaración de lo que entiende por mirada femenina: rechazando la idea de que se trate de "una esencia preexistente” y subrayando que "no depende del sexo biológico de quien escribe o lee”, acierta en precisar que se trata de "algo a construir, un punto de llegada, un producto histórico, un hito político de características inimaginables que no surge, algo que crece en una práctica social no necesariamente consciente de sí misma, algo ... a lo que pueden acceder mujeres o varones”. (463) Planteándola con conceptos e imágenes espaciales relacionadas con la mirada, agrega a la definición de mirada femenina, los siguientes rasgos: 
Entendemos por 'mirada femenina' ese punto de vista en el cual la lucha de géneros no se niega o minimiza, sino que queda evidenciada, esa perspectiva que aprovecha el lugar lateral desde donde observa para ver algo que desde un lugar céntrico no se ve. Por lo tanto, ... es casi siempre vacilante y contradictoria, es más bien un momento, un atisbo, un ojo bizco que observa, en una sociedad donde las mujeres "ya no" son tan masivamente las que tratan de obedecer a los modelos masculinos que la cultura les obligó a internalizar, pero "todavía no" son mujeres libres de ellos. (463)

Silvina Ocampo, observa Marcelo Pichon Riviere, “tejía sus escritos a la sombra — o en los bordes — de los que escribían Adolfo Bioy Casares, su marido, y Jorge Luis Borges, su amigo” (cit. en Drucaroff). A pesar de repetir el recurso de apelación a las figuras “consagradas” y por ende “legitimadoras” que, desde el punto de vista feminista, responde a un patrón de la sociedad patriarcal, la observación de Pichon Riviere acierta en la selección del término “bordes” para designar el lugar de la enunciación que elije Ocampo: “[H]a escrito en los bordes de las convenciones literarias de su generación y las ha desbordado en forma sutil y feroz” (ídem). Sin embargo, el acierto de la observación no redime el encuadre del pasaje plagado de tópicos del discurso patriarcal:

En efecto, el lugar lateral al que por su condición de género la escritora estaba condenada se volvió en su poética el gran mecanismo productivo: retomando con voz chirriante la estética decimonónica del cuento realistapsicologista, o fantástico, o policial, o gótico, riendo bajo pero con acidez implacable, exhibiendo con impudicia un lenguaje que rehúsa la 
perfección que todos celebran, por ejemplo, en la narrativa de su marido, Silvina construyó relatos extraños, en los que la perversión, la crueldad y la ironía eran desmesuradas, relatos que si se juzgaban con los parámetros estéticos conocidos parecían chatos o incluso fallidos, pero que dejaban la tremenda inquietud de no parecerse a nada de lo que se había escrito hasta entonces (464) (el énfasis es mío).

Vemos en este pasaje las aproximaciones fallidas a la caracterización de la obra de Silvina Ocampo que repiten los lugares comunes que plagan sus reseñas biográficas. Si Ocampo escribe desde el lugar lateral, no es por obligación sino por elección. No es posible aproximarse al lenguaje singular que plantea su estética a partir de la especificación de su diferenciación con el de Bioy Casares pues sería partir del presupuesto del vínculo como elemento formador. Es evidente que críticos, escritores, periodistas, a sabiendas o inadvertidamente, han contribuido a repetir mecánicamente la muletilla de los nombres famosos que rodean a Silvina Ocampo para caracterizar su obra e identificar a su autora sin detenerse a pensar en las implicaciones de tal elección o en la futilidad de dicho enfoque.

Ya en el ámbito del estudio de la literatura femenina, se ve un avance hacia la independización de Ocampo. Avanzando en su análisis, Drucaroff adopta una caracterización de la obra ocampeana de mérito propio citando nuevamente a Pichón Riviére: "Figura solitaria en la literatura argentina. No pertenece a ninguna escuela y a veces parece que no pertenece a ninguna época” (465) y la toma como referente en una comparación para presentar a otra escritora argentina, Fina Warschaver (1910-1989), 
“valiosa narradora, dramaturga, poeta, ensayista, y música casi desconocida” que inicia el desarrollo de la idea de la paradoja en la literatura femenina argentina. Drucaroff explica: Si Silvina Ocampo trabajó generalmente con la narrativa decimonónica, deshaciendo bruscamente la "belleza" de un estilo refinado... [Warschaver,] en los cuentos de Hombre-Tiempo utiliza el vértigo de la asociación libre, la ruptura de la sintaxis y la lógica temporal y otros recursos vanguardistas para crear una literatura que no se parece a nada.

Más adelante, Ocampo vuelve a servirle de referente en la caracterización del enfoque programático de otra escritora, Angélica Gorodischer: "Sus dieciséis libros parecen responder a un tácito, inconsciente programa político muy diferente del que surge de hecho de la literatura de Ocampo: irrumpir desde los márgenes hacia el centro del sistema literario” (470). Según Drucaroff, Gorodischer continúa en ciertos aspectos el linaje de Silvina a partir de su trabajo con la crueldad infantil, sobre todo de las niñas y de las mujeres; de la investigación sobre la mirada lateral de los marginados, constante de muchas búsquedas femeninas; o bien del uso del humor como herramienta crítica en proyectos culturales feministas. La comparación concluye de la siguiente manera: "Si la poética que creó Ocampo opera con el mamarracho genial hecho en el margen de la hoja de la narrativa consagrada, Gorodischer irrumpe en el centro de la serie literaria sin que nadie la invite y se instala con toda naturalidad ahí...” (471). Resulta éste un acercamiento más natural y que reconoce las características singulares de la obra de Ocampo, las cuales le designan un espacio propio en las letras argentinas del siglo XX. 
CAPÍTULO 2 - Modalidades del fantástico

Analizar el fantástico en la obra de Ocampo requiere un acercamiento matizado y multifacético dadas las intersecciones y superposiciones de los modos de enunciación, la estructura narrativa y las convenciones del género. Es decir, se trata de observarla en todos sus aspectos en forma simultánea a fin de construir una imagen más completa y plural.

Fue Tzvetan Todorov, el crítico estructuralista, quien desarrolló el marco teórico del género, publicado en el texto base The Fantastic (1973). Si bien su estudio se basa principalmente en textos representativos de la ficción europea decimonónica ${ }^{14}$, sus postulados permiten la extrapolación para el análisis de otras obras que caen dentro de coordenadas afines, como es el caso de la literatura fantástica del siglo XX.

Para el análisis de los cuentos de Ocampo resulta particularmente útil su noción de "vacilación”. Todorov plantea que la vacilación es el elemento esencial del fantástico. "Either total faith or total incredulity would lead us beyond the fantastic: it is hesitation which sustains its life” (Todorov, 31). Tomar este rasgo del género como punto de partida para el estudio de la obra de Ocampo da resultado. Hay varios cuentos que exhiben este elemento. Sin embargo, es necesaria una disección del texto para determinar cómo actúa este elemento a fin de derivar constantes que ayuden a la caracterización del estilo de Ocampo. Claro está que la presencia de tal elemento no es prueba suficiente ni definitiva para clasificar a un autor como exponente del fantástico o a su obra come ejemplo de él. Hecha esta salvedad, nos adentraremos en el análisis de la obra ocampeana desde el

\footnotetext{
${ }^{14}$ El estudio de Todorov incluye el análisis de textos “clásicos” como los cuentos de Charles Perrault (s. XVIII) hasta "La metamorfosis” de Kafka, publicado en 1915.
} 
marco teórico del fantástico según lo expone Todorov para establecer las líneas de demarcación y los puntos de partida necesarios para mostrar la modalidad del fantástico que estas obras proponen.

La estética del fantástico es la más propicia, frente a la del surrealismo o del realismo mágico, par iniciar la definición a partir de comparaciones y contrastes. Entendiendo que "Poetics... has concerned itself with genres as codifications of procedures and responses...[,] Todorov examin[es] the codes shared by writer and reader that enable a certain kind of communication to take place. A literary text is a linguistic event—but an extraordinary one, with literary coding superimposed on the language itself” (Robert Scholles, foreword to The Fantastic, viii). En marcada oposición a la concepción aristotélica de los géneros, de carácter estático, los estrutcturalistas have given us the notion of literary types as forming in their aggregate and incomplete system, constantly seeking equilibrium, but always disturbed by new cultural intrusions from beyond the world of letters itself. Thus genres persist like any convenient codification of cultural behavior but come into periods of fruition and dominance when most responsive to other cultural needs — only to harden, to atrophy, and be replaced by others. This incomplete system offers freedom for the writer, because no genre is itself ever complete—it is modified, as Todorov suggests, by each new work of imagination—and because the system itself is always open, with weak or neglected genres offering increasingly attractive possibilities for writers driven to "make it new.” (idem, ix). 
Uno de esos géneros débiles o descuidados sería el fantástico, por ejemplo, que había sido relegado a un segundo plano desde la irrupción del realismo y naturalismo predominantes en la sociedad positivista de fines de siglo XIX, por un lado, y del modernismo (y el decadentismo) con su lirismo exaltado y su aislamiento en torres de marfil, por el otro, hasta que las vanguardias comenzaran a allanar el camino para su retorno o, mejor dicho, para que se abriera paso.

Antecedentes en el Río de la Plata

Como precursores de los albores del género en la Argentina, Leopoldo Lugones y Horacio Quiroga introducen las primeras manifestaciones del fantástico de valor literario. En la década del veinte, Macedonio Fernández y Jorge Luis Borges llevaría el género a un nuevo nivel, donde "la realidad se desintegra hasta transformarse en un vacío o en una ficción” (Willson 32).

En este punto es interesante notar el caso de Felisberto Hernández que resulta en muchas maneras análogo al de Silvina Ocampo. El escritor y músico uruguayo también escribió relatos fantásticos y cultivaba un estilo original, en palabras de Ítalo Calvino: “un escritor que no se parece a nadie: a ninguno de los europeos y a ninguno de los latinoamericanos, es un francotirador que desafía toda clasificación y todo marco, pero se presenta como inconfundible al abrir sus páginas” (cit. en Ulla Encuentros 56). Sin embargo, su obra no fue objeto de estudio y mayor difusión sino hasta mediados de los años setenta, lo cual resulta paradójico pues tanto Cortázar como García Márquez no sólo lo admiran sino que lo toman como referente de sus obras. 
Hacia 1940, el fantástico en la Argentina registra un desarrollo acelerado, gracias a la intervención de un grupo de escritores relacionados en forma más o menos directa con la revista Sur, hacia la cual gravitaba un grupo de intelectuales y escritores cuya concepción de la literatura era particularmente afín a la modalidad fantástica: Jorge Luis Borges, Adolfo Bioy Casares, Silvina Ocampo, José Bianco, Manuel Peyrou, Manuel Mujica Láinez, Julio Cortázar, entre otros. (Willson 33) A pesar del carácter particular y personal que cada autor le imprime a su obra, en términos de la consolidación de esta poética del cuento y sus leyes de composición precisas, las obras pueden leerse desde contexto mayor de la tradición literaria argentina:

Los autores del fantástico argentino de los años cuarenta y cincuenta vienen a realizar o expandir lo que Borges había iniciado... y que aparece formulado en un texto que establece todo un programa: el prólogo que Borges escribe para La invención de Morel en 1940. En él hay un rechazo explícito de la descripción realista-naturalista y del psicologismo en literatura, y una marcada predilección por la “imaginación razonada” y las tramas perfectas, sin elementos adventicios o superfluos... Borges se pronuncia en contra de las tendencias que imperaban en la novela del siglo XX -la pobreza en peripecias, la abundancia de introspección—, y propone una nueva forma de concebir lo literario, basada en el rigor compositivo y en una causalidad racional pero no imitativa, como en la novela realista, sino artificial, literaria, fantástica. (36)

En el mismo estudio, Willson hace una excepción en el caso de Ocampo, una excepción que confirma la regla, podría decirse, pues ya es costumbre cuando la crítica se 
enfrenta a su obra. En este sentido, observa que en su obra "el carácter fantástico reside ante todo en la cualidad lábil y atípica del punto de vista” $(36)^{15}$ destacando una de los rasgos sobresalientes de su obra que hemos identificado como el constituyente de la modalidad del fantástico que le es propia, a la vez que la diferencia de las convenciones del género.

Podría argumentarse que la afiliación de un autor y su obra a un género determinado como en este caso, entre la obra ocampeana y el canon fantástico, es irrelevante e independiente del acto de lectura. Sólo sería el caso de un lector no iniciado, pero no el del lector que exigen los textos de ficción del siglo XX a partir de la irrupción de las vanguardias y las estéticas posteriores. Tomemos, por ejemplo, el lector implícito que conjuran los textos de Borges o Cortázar, al que este último bautizó el "lector cosufriente” (o lector activo). La observación de Scholles acerca de la poética resulta útil de igual manera en el análisis: "we must finally acknowledge that we cannot even recognize uniqueness except as a deviation from some norm. A world of unique objects would not only be overwhelming and intolerable; it would not even be perceptible” (ix). Está claro que para reconocer la singularidad de la obra de Ocampo, la única manera de que resulte manejable, conocible, es a través de un acercamiento desde una perspectiva de género, a partir de la cual pueda posicionarse y exhibir los rasgos que la distinguen. Como bien observa Scholler: “Common concern for literary genres [is] fundamental to our perception of fiction”. (x)

\footnotetext{
${ }^{15}$ Véase, por ejemplo, el cuento "Viaje olvidado", en el cual el punto de vista del narrador niño es el elemento que configura el relato como un cuento fantástico a partir de la vacilación que suscita en el lector implícito que se debate entre la literalidad del lenguaje en la experiencia infantil frente a la referencialidad de los hechos narrados.
} 
Uno de los hechos literarios que sedimenta la afiliación o, mejor dicho, la relación de Ocampo con el fantástico es su colaboración con Borges y Bioy Casares en la selección, traducción y edición de la Antología de la literatura fantástica en 1940, seguida de una nueva edición ampliada en 1965. Balderston señala el “carácter didáctico -y hasta evangélico—” (217) que se desprende del prólogo y la posdata, y acota que "el fervor que sentían los antólogos y su círculo ... por la literatura fantástica le da a la antología algo de ese carácter de manifiesto que tenían algunos textos de las vanguardias de quince o veinte años antes” (218).

Por otro lado, la teoría del fantástico de Todorov deviene un marco de referencia apropiado para el análisis de la modalidad del fantástico ocampeano dado que, como explica Sholles, "Todorov seeks linguistic bases for the structural features he notes in fantastic texts”. (x) Éste es el enfoque que hemos adoptado para el análisis de los textos de Ocampo y podemos anticipar en este punto que es en el plano lingüístico de sus narraciones donde se configura y se encuentra su particular concepción del fantástico.

En las obras de Ocampo, la irrupción de lo fantástico no se opera exacta ni estrictamente según las convenciones del género que propone Todorov. En cambio, se manifiesta de una manera particular: se crea en el plano lingüístico dado que es a través del lenguaje que la desfamiliarización (das Unheimliche en alemán o the uncanny en inglés) se filtra lentamente y corroe la percepción del lector, haciéndolo dudar de ella e impulsándolo a volver sobre el texto y releerlo a fin de comprobar que no se trate de una percepción errónea, de una mala lectura de su parte. El lector es inquietado por el narrador no fidedigno que constantemente asedia su confianza; por el lector implícito con el cual no puede asociarse, dados los espacios de indeterminación que se lo impiden; por 
la yuxtaposición de imágenes contradictorias dispuestas con la mayor naturalidad, las cuales llegan a desafiar el marco de referencia ontológico del texto y crean un universo a su antojo, plausible, verosímil, a partir de descripciones minuciosas y vívidas, pero donde puede suceder cualquier cosa, donde lo absurdo es la regla, no la excepción. ${ }^{16} \mathrm{~A}$ propósito de su particular manifestación del fantástico, Alberto Manguel nota: “Silvina Ocampo acepta lo fantástico con ingenuidad. Sabe que tiene sus leyes, pero no moraliza sobre ellas. Permite que la situación hable por sí misma con la máxima sencillez, como en un cuento de niños. No ignora sin embargo lo terrible de esa ingenuidad, que no desdeña el humor.” (20)

Por tratarse del plano lingüístico, el análisis debe enfocarse desde un marco teórico afín. El mecanismo de interpretación de un texto desde otras lecturas, incluidas las teóricas, sigue la dinámica que propone la denominada teoría de la recepción sistematizada, entre otros, por Wolfgang Iser en La estructura apelativa de los textos. Basados en el esquema de comunicación de Roman Jakobson, podemos equiparar el acto de interpretación al acto de habla con énfasis no en el código sino en el receptor. Este procedimiento no es muy distinto del acercamiento que cualquier lector de a pie puede realizar, sólo que desde ese lugar de enunciación, el lector-crítico informa el texto con el repertorio de sus lecturas con el que actualiza el texto llenando los “espacios vacíos” o “intersticios” de significación que existen entre lector y texto (Iser 138).

El análisis crítico es un acto de lectura que reescribe el texto que el autor propone. Para que el lector pueda llenar los intersticios de significación, es requisito que éstos

\footnotetext{
${ }^{16}$ Es necesario acotar que el uso de imágenes paradójicas e incongruentes y su predilección por el oxímoron debe distinguirse de las propuestas de la estética surrealista o absurdista propiamente dicha, si bien constituye un importante punto de contacto a nivel estilístico.
} 
existan, es decir, que se trate de un tipo determinado de texto. Debe tratarse de textos abiertos, que muevan al lector a la producción de significado (Iser 136). En este sentido, a propósito de la narrativa de Ocampo, Pezzoni señala: "Hay algo que retrocede sin cesar, que espera en algún lugar del texto. No es la caricatura ... sino la transmutación ... Se insinúan y hacen llamados los sentidos múltiples, que a la vez no se dejan atrapar”. (11-2)

Dicho esto, conviene tener en cuenta que siempre se hace una lectura. Ésta, al mostrar la distancia entre el texto "real” y el texto interpretado (actualizado), entre el autor "real” y el autor que se construye, se convierte en una herramienta de investigación, porque incita a elucidar posibles significados, señala vías de acercamiento. Si lo que existen son actualizaciones del texto, habrá tantas lecturas como críticos. Algunas serán más privilegiadas que otras pues está claro que la diferencia dependerá de la habilidad para mostrar vínculos percibidos como más exactos, o interpretaciones consideradas más acertadas. No se puede escapar a la formación de un orden jerárquico pero al abrir el abanico de posibilidades, sin duda se enriquece el significado del texto.

El conflicto en "Viaje olvidado"

"Viaje olvidado" integra la primera colección de cuentos que publicó Silvina Ocampo en 1937 bajo el título homónimo. La voz narrativa introduce el conflicto de una niña “Quería acordarse del día en que había nacido” y elige la tercera persona pero el tono sencillo se acerca al lenguaje infantil, lo cual favorece la identificación con el discurso de la protagonista. La voz narrativa habla por la niña: “Fruncía tanto las cejas que a cada instante las personas grandes la interrumpían para que desarrugara la frente. 
Por eso no podía nunca llegar hasta el recuerdo de su nacimiento” (CCI 73) ${ }^{17}$, pero también como si fuera la niña, ya que no cuestiona ni juzga la validez del motivo al que se atribuye el fracaso.

Cabe señalar que una de las características del lenguaje primitivo es la literalidad, la ausencia de distancia metafórica entre el referente y el signo, que se traduce en identidad. El narrador testigo revela su fe en lo narrado, en la identidad entre el lenguaje y la realidad referenciada. Así, la afirmación “Los chicos antes de nacer estaban almacenados en una gran tienda en París, las madres los encargaban, y a veces iban ellas mismas a comprarlos” (CCI 73) es expresión del saber de la niña sobre el origen de los bebés, que, por articularse como generalización, da la idea de que es compartido por el narrador y aún más, que el narrador se expresa desde el punto de vista de la niña. Esto está reforzado en el mismo párrafo por la ambigüedad de la primera-tercera persona facilitada por la identidad de las formas verbales, lo cual transmite la indeterminación del narrador: "Hubiera deseado ver desenvolver el paquete, y abrir la caja donde venían envueltos los bebés” (CCI 73). La conjunción adversativa y el pronombre personal "la” vuelven a trasladar la voz narrativa a la tercera persona: “pero nunca la habían llamado a tiempo en las casa de los recién nacidos” (CCI 73). En palabras de Mackintosh, “[p]art of Ocampo's seductive charm is her ability to shift perceptively (and sometimes imperceptibly) between child and adult viewpoints” (77) los cuales, en este caso, están amalgamados.

\footnotetext{
${ }^{17}$ A fin de simplificar las referencias a los textos primarios designo CCI y CCII al primer y segundo volumen de Cuentos completos respectivamente.
} 
El cuento narra el desasosiego que conlleva el crecimiento, el paso de la niñez a la pubertad, y la resistencia a lo que se ve como la pérdida irreparable de la inocencia, la caída.

La niña identifica su nacimiento con el primer recuerdo que puede evocar: "Pero ella había nacido una mañana en Palermo haciendo nidos para los pájaros” (CCI 73). Esto supone un paso más allá del planteamiento inicial “no podía llegar hasta el recuerdo de su nacimiento” y del conocimiento dado (los bebés vienen de París), por lo cual supone una individualización de la experiencia que hace la niña (ella nació en Palermo haciendo nidos), aunque dentro de los marcos de la fabulación infantil. Como no hay referencia a un tiempo determinado, nada impide que se identifique este recuerdo con el momento de la percepción del yo, cuando toma conciencia de sí y se diferenciada del mundo externo “as the source of the sensations flowing in upon him” (83), en términos de Freud. En el relato están presentes las sensaciones “de haber hecho un viaje sin automóvil ... lleno de sombras misteriosas”, “haberse despertado”, “olor a casuarinas”, encontrarse “de repente haciendo nidos” (CCI 73). Esto reafirma el hecho de que si bien la niña individualiza la experiencia y remplaza una afirmación por otra, ambas están dotadas del mismo carácter literal, de la misma certeza que las hace idénticas a la realidad.

La primera duda, el primer anticipo de la caída, sin embargo, no tarda en aparecer. Para la angustia que le produce el reconocer el cambio (la ausencia de los nidos), las palabras de la niñera (se los llevaron los pajaritos) en el mismo código infantil sólo ofrecen consuelo transitorio, porque son de inmediato refutadas por la crueldad de la hermana tres años mayor, que señala el contraste con la experiencia empírica (el placero que barre el último nido), típica del mundo adulto. De allí en más comenzará el 
distanciamiento entre el signo y el referente que da paso a la angustia: “sintió ganas de lanzar” (73).

El hecho, además, despierta la conciencia del tiempo a partir de un hecho diferenciador que lo ha puesto en marcha y trae aparejado el desasosiego de saber que el tiempo pasa inexorablemente: "Y después, el tiempo había pasado desde aquel día alejándola desesperadamente de su nacimiento” (73, énfasis mío). De la indiferenciación temporal a la percepción del paso del tiempo. Según Mackintosh, “It is the child’s feeling that life is infinite which is lost to the adult, whose sense of time inexorably passing is all too highly developed” (88) lo cual se confirma en la niña y marca el hecho del crecimiento. La diferenciación conlleva una sensación de extrañeza ante la paradoja de lo distinto y lo igual: “cada recuerdo era otra chiquita distinta, pero que llevaba su mismo rostro” (73). La frase expresa la imposibilidad de reproducir el recuerdo original al introducirse variantes en cada evocación porque el paso del tiempo juega con la memoria a corto plazo y el contraste con la memoria a largo plazo, o permanente, en la que se aloja la identidad: la niña se reconoce ("llevaba su mismo rostro”). A pesar de ello, la percepción se mantiene en términos infantiles “Cada año que cumplía estiraba la ronda de chicas” (73-74).

Molloy señala la imposibilidad de los niños de tomar las exageraciones del lenguaje metafóricamente, por lo cual en su mente la amenaza “Te voy a matar” se transforma en el hecho en sí: “Los niños de estos cuentos son aceptados literalmente, sin que medie la posibilidad de una traducción entre la palabra y el hecho. Las declaraciones no se reducen a impulsos agresivos sino que se ajustan fielmente a lo que enuncian” (Molloy 171). Extrapolando la información, se puede ver una correlación de ello en el 
cuento a partir de otra revelación que refuta el conocimiento dado: las "palabras atroces, llenas de sangre” dichas “despacito, más fuerte que si hubiera sido fuerte: ‘Los chicos están dentro de las barrigas de las madres y cuando nacen salen del ombligo’” (74). Una vez más se presenta el punto de vista de la niña por el cambio a primera persona: “y no sé qué otras palabras oscuras como pecados habían brotado de la boca de Germaine, que ni palideció al decirlas” (74 énfasis mío). Son las nuevas experiencias: nuevas palabras, nuevos sentidos de las palabras, que, unidas a un conocimiento imperfecto, sólo pueden dejar la impresión de ser “oscuras como pecados” y producen nuevos sentimientos de corte negativo: la vergüenza proyectada en el otro: “que ni palideció al decirlas” (74). El siguiente paso lógico es la constatación empírica: “Entonces empezaron a nacer chicos por todas partes. Nunca habían nacido tantos chicos en la familia”. En este caso, corrobora la revelación y aumenta la vergüenza. De allí, lo que sigue es el cuestionamiento, la puesta a prueba de los informantes: “le confió a Micaela su horrible secreto, riéndose" (74). Es notable la ambivalencia que introduce el término, pues puede indicar la inocencia, el juego como estrategia para evitar el castigo o bien, el sarcasmo, la superioridad que le concede el secreto y el contradecir al mayor —una rebeldía incipiente. La reafirmación del mundo original le produce “un pequeño alivio. Pero cuando la noche llegaba, una angustia mezclada con los ruidos de la calle subía por todo su cuerpo. No podía dormirse de noche aunque su madre la besara muchas veces antes de irse al teatro. Los besos se habían desvirtuado” (74). La inquietud aumenta y los métodos tradicionales no logran apaciguarla.

Finalmente llega el golpe de gracia: la revelación por parte de la madre que "se mezclaba a los secretos horribles de Germaine” (74). Si quedaban dudas sobre la 
posibilidad del regreso, la revelación las hace desaparecer. La angustia llega a su punto máximo: "Pero ella sostuvo desesperadamente que los chicos venían de París” (74). Esta vez, el mantra no surte efecto, las palabras pierden su poder de nombrar la realidad, el recurso del lenguaje ya no sirve.

El ciclo se completa y culmina con el trastoque del mundo infantil que se comprueba en la percepción desfamiliarizada: “el rostro de su madre había cambiado totalmente debajo del sombrero con plumas: era una señora que estaba de visita en su casa” (74). La tragedia total vuelve a comprobarse en la pérdida del poder de identidad del lenguaje y en su materialización de lo opuesto: "cuando su madre dijo que iba a abrir la ventana y la abrió... quedaba más cerrada que antes y cuando dijo su madre que el sol estaba lindísimo, vio el cielo negro de la noche” (74 énfasis mío). En la percepción de la niña la palabra se contradice con la experiencia empírica.

El cuento narra un hecho arquetípico, el rito de paso de la niñez a la pubertad. Sin embargo, la nostalgia por la inocencia perdida se establece mediante los signos negativos. Se exalta la tragedia de haber dejado atrás la niñez y no se deja más que un oscuro prospecto por delante. En este sentido podemos decir que el cuento evidencia rasgos primitivistas, el punto de vista infantil e ingenuo y un tratamiento desfamiliarizante de los hechos en coincidencia con esta perspectiva particular que tiñe de irrealidad los hechos narrados.

El lenguaje creador y "El castigo"

La selección del texto “El castigo”, que se incluye en el volumen La furia y otros cuentos, publicado en 1959, obedece a la detección de rasgos que enriquecen el análisis 
por contraste con elementos que definen el canon mágico-realista, que Todorov diferencia del fantástico. Dichos elementos son: a) el punto de vista ideológico primitivo de la narración; b) la transculturación de convenciones de lo real (Camayd 51). Si bien se detecta un elemento primitivista en el cuento, éste no marca el punto de vista ideológico de la narración, como en el caso de Ti Noel, en El reino de este mundo de Alejo Carpentier, que presenta la visión del mundo del ser primitivo, donde los sucesos que parecen extraños tienen una significación oculta al no iniciado, o donde lo sobrenatural es moneda común y lo familiar es lo extraño. Así se configuran las bases para la suspensión de la incredulidad ante lo desfamiliarizante pues lo extraño se naturaliza apelando al hecho de que se trata de la visión de un ser primitivo. En cambio, el rasgo primitivo que exhibe el cuento de Ocampo participa solamente de una parte de la cosmovisión primitivista: alude al anhelo de retorno al origen, es decir, a un primitivismo psicológico. Los impulsos del personaje femenino, sus emociones parecen orientarse hacia el pasado, buscan un momento anterior en el tiempo, al que quiere regresar -independientemente de si puede o no—y se valora más debido a lo problemático que resulta el presente. Este rasgo además está plasmado con un recurso narrativo, el diálogo, que tematiza otra característica del modo de pensar primitivo: un paradigma que el transcurso del tiempo ha borrado, donde signo y referente son la misma cosa, donde no hay abstracciones ni modulaciones que relativicen los vínculos. Asimismo se revela en el intento de reproducción del punto de vista de una mentalidad infantil y por recurrir a la locura o lo irracional, manifestaciones del subconsciente que irrumpen en el plano consciente, para dar cuenta de conductas o hechos salen de la norma. 
El segundo elemento de la narrativa mágico-realista es la transculturación de las convenciones de lo real, es decir, qué es lo que se entiende por realidad objetiva consensuada en una cultura arcaica. En el caso del realismo mágico, este elemento permite establecer nuevos parámetros para lo normal, lo convencional, que distan de la realidad del lector, pero que éste debe aceptar precisamente por ser ajenos a su entorno, por ejemplo, una distinta concepción del tiempo o del lenguaje.

La narración comienza con una frase mínimamente descriptiva: "Estábamos frente a un espejo que reflejaba nuestros rostros y las flores del cuarto” (CCI 277). La primera persona del plural conjura un narrador en primera persona y anticipa la presencia de, por lo menos, dos personajes, uno de los cuales hará las veces de narrador. Lo que parece un detalle nimio, un comentario al pasar sobre la decoración del cuarto donde transcurre la escena, o mejor dicho, el diálogo, cobrará importancia más adelante como elemento que cierra el relato. Esta descripción mínima, esta economía del lenguaje, hace que la historia avance. La elección del diálogo como recurso de preferencia propicia la identificación del lector, tanto el real como el implícito, con el personaje de la historia y el interlocutor “-_iQué te pasa? -le pregunté. Estaba pálida. -¿Me ocultas algo?” son las primeras palabras del narrador en discurso directo, las cuales sirven para identificar al interlocutor como mujer. El narrador no tiene todavía una marca de género. Ocampo usualmente evita los adjetivos con marcas de género para dejar al lector a oscuras y jugar con sus presunciones. En esta historia, el hecho de que el interlocutor sea mujer podría sugerir que el hablante fuera hombre. En esta historia, resulta ser cierto, pero en muchas otras la expectativa no se verifica, ya sea porque el hablante es mujer o porque la ambigüedad queda sin resolver. “-No te oculto nada. Este espejo me recuerda mi 
desventura: somos dos y no una sola persona -dijo, tapándose la cara——.” La atención del lector es captada por la mención de otro objeto que se encuentra en el cuarto: un espejo, acompañado de una alusión enigmática a que el espejo es símbolo del conflicto que vive la pareja, en boca de la protagonista. El espejo se instala como el eje del desarme y la individualización de la identidad de cada uno de los personajes (Yo-Otro/Ser-Imagen), lo cual indica el fin de la relación. Sigmund Freud explica el proceso de identificación y diferenciación que se entabla en las relaciones humanas de la siguiente manera: “At the height of being in love the boundary between ego and object threatens to melt away. Against all the evidence of his senses, a man who is in love declares that 'I' and 'you' are one, and is prepared to behave as if it were a fact" (Freud 83 énfasis mío). Es Lacan, quien, notablemente, identifica el espejo como elemento de la etapa decisiva en el desarrollo del yo, pues mediante él, el yo reconoce su autonomía y su diferenciación del todo. Esta declaración confirma que el cambio de percepción procede del fin del amor, un hecho, a partir del cual, se dará una restructuración de la conducta, una recomposición a su estado original.

Así como el deslinde se opera en la imagen, la diferenciación, es decir, la separación del todo y la recuperación de la identidad individual se opera en el lenguaje y mediante él, operando, además, una reconfiguración del espacio. La protagonista toma la palabra, el centro de la acción:

Al verte tan severo, me siento culpable. Todo me parece una infidelidad. Tengo veinte años ¿Par qué me sirven? Por miedo de perderme no quieres que mire, ni que pruebe nada, no quieres que viva. Quieres que sea tuya definitivamente, como un objeto inanimado. Si te hiciera el gusto, 
terminaría por volver al punto inicial de mi vida o por morir, o tal vez por volverme loca —me dijo—. ¿ No te da miedo? (CCI 277).

Es interesante notar que la frase conjuga los conceptos de muerte, locura y regreso $a b$ ovo, probablemente por la particularidad de que estos elementos comparten la anulación de todo sentimiento de placer o de dolor.

El protagonista replica: “-Me ocultas algo -insistí-. No trates de distraerme con lamentos” a lo que la respuesta no se hace esperar: “-Si crees que te oculto algo, me remontaré a mis veinte años -me dijo—y te contaré toda mi vida. Haré un resumen” (277). Estas palabras anticipan los hechos que se desarrollarán en el cuento, pues la protagonista narrará los hechos de su vida. Sin embargo, el lector comprueba una anomalía que inicialmente se manifiesta sólo en la enunciación: los hechos no correrán en sentido lineal del origen al presente sino en sentido inverso, del presente al origen en un retroceso literal. Se produce aquí el desdibujamiento de las líneas de demarcación de la metáfora, su signo y su sentido, en las obras de Ocampo. El lenguaje recupera y extiende al máximo su capacidad de nombrar, un poder que la gramática inglesa identifica como "performative aspect” (a veces traducido como "poder ilocucional”). Una de las lecturas que exige este texto es el reconocimiento de la noción de que el lenguaje tiene el poder de "llamar a las cosas que no son como si fuesen”, de darles vida al pronunciar su nombre, es decir, que el lenguaje ha recuperado su potencia creadora y que lo que se enuncia, es. Algo que llama la atención es que la evocación se inicia tras un cambio en la ya escueta escena: “Déjame recostar mi cabeza sobre tus rodillas porque tengo sueño. Me acomodé en el sofá y dejé que se apoyara cómodamente sobre mí, meciéndola como a un recién nacido.” Estos detalles: el sofá y el sueño pueden leerse como un guiño de la 
autora por tratarse de elementos asociados comúnmente con el psicoanálisis. Asimismo, la mención del recién nacido se registra como refuerzo del origen, el punto al que se dirige la narración. De alguna manera, evocan ciertas imágenes en la mente del lector que dosifican la lectura y la dirigen hacia el plano de lo onírico, de la infancia, locus de preferencia del material subconsciente. De esa manera, más o menos consciente, se atrae al lector hacia un plano donde, por convención, se suspende la incredulidad y se pueden aceptar hechos que se apartan de lo que se considera normal.

Otro elemento significativo de este acto de habla es que emplea la primera persona, como es típico del tono confesional, pero se refiere al interlocutor en tercera persona, introduciendo el primer elemento de indeterminación, de duda, a saber, la presencia de los dos personajes en el mismo contexto de enunciación. (Sobre esto volveremos al comentar el final del relato.) El protagonista masculino, al sentirse aludido en tercera persona, intenta interrumpir la enunciación y producir el cambio esperado de “él” a "tú”. Sin embargo, la narradora contesta sólo a la primera pregunta: “-¿¿Por qué me nombras como si hablaras de otra persona?” desconociendo la identidad del interlocutor y refiriéndose a él por su nombre, Sergio, pero en tercera persona. La transformación que se comprueba en el plano lingüístico, la explica en detalle Molloy:

la convención gramatical estalla definitivamente: el narrador que abre (y cierra) el relato se ve reflejado en un espejo con un tú que se adueña de la narración y se confiesa ante él tratándolo en tercera persona. A partir de esa distancia el yo que se confiesa desanda su vida, anulando la posibilidad del tú, se transforma—como todos los narradores de Silvina Ocampo — en un yo que habla en el vacío, que quiere agotar sus 
posibilidades diciéndose, sin reparar en las convenciones. Al final del cuento, el primer narrador retoma el relato... La verbalización llega a anular literalmente, en este caso, al personaje. (170-1)

La narración discurre sin interrupción hasta las primeras sensaciones que es capaz de evocar: "No reconocía las letras: ni la o, ni la a, que eran tan fáciles ... Comencé a probar el gusto de algunas frutas, de algunas sopas; luego, el gusto dulce de la leche.” Y son sus últimas palabras: "Ésta es mi vida -me dijo, cerrando los ojos—. Recordar el pasado me mata” (281). A partir de entonces, no vuelve a escucharse la voz femenina. El narrador retoma la palabra para explicar enigmática y escuetamente los hechos que le sucedieron:

-¿Te burlas de mí? -le pregunté. No me respondió y apretó los labios: jamás volvió a abrirlos para decirme que me amaba. No pude llorar. Como si la contemplara desde la cima de una montaña, la miré, lejana, indefensa, inexpugnable. Su locura era mi único rival. La abracé por última vez y fue como una violación. Durante el relato, el tiempo, para mí, había transcurrido a la inversa: para ella, veinte años menos, significaron para mí veinte años más. Eché una mirada al espejo, esperando que reflejara seres menos afligidos, menos dementes que nosotros. Vi que mi pelo se había vuelto blanco.

La conclusión parece registrar un hecho desfamiliarizante, típico de las convenciones del relato fantástico. El regreso de la protagonista en el tiempo del relato registra la regresión temporal del personaje hasta llegar al momento anterior a la existencia que, en este caso, equivale a la inexistencia, a la muerte. Será necesario evaluar 
hasta qué punto esta realidad se corresponde con la estética de lo fantástico. “La alteración del curso normal del tiempo es un tema que tanto Borges como Callois y Bioy Casares, entre otros, han destacado como tema privilegiado de los relatos fantásticos. El tiempo alterado provoca una inquietud que recae en la extrañeza de lo fantástico” (Espinoza-Vera 140). Según Todorov, "Literature of the fantastic is concerned to describe desire in its excessive forms as well as its various transformations or, one may say, its perversions” (138). Bien puede afirmarse, entonces, que el exceso del deseo logra efectuar la transformación temporal: el acto de habla ha materializado el cambio narrado para el hablante. Mientras tanto, para el interlocutor que quedó fuera del acto de habla, el tiempo ha seguido igualmente anómalo pero en sentido inverso. Sin embargo, la incertidumbre queda en pie, no se resuelve o, mejor dicho, no puede resolverse simplemente con una explicación que se ofrece dentro del relato, mucho menos cuando está en boca del narrador, quien abre y cierra el relato, y por lo tanto, esa posición jerárquica lo hace poco fidedigno. Es el lector, en última instancia, el que tiene "la última palabra”. Si lo toma exclusivamente como relato fantástico, el cuento no decepciona porque los elementos de la sorpresa y el efecto de la desfamiliarización logran su cometido.

Sin embargo, en el caso de "El castigo", el lector se enfrenta a un texto donde se presentan hechos aparentemente inexplicables con una naturalidad inusual, como si fueran parte del orden del día, parte integral de la realidad. Esto no quiere decir que se haya construido una versión de lo real que acomode estas peculiaridades como es característico en la estética mágico-realista. Este elemento, junto con el primero, configuran a un lector implícito particular que, según Camayd, “está llamado a jugar un 
doble papel, el del creyente y el del escéptico" dado que “[s]e producen dos niveles semánticos en la lectura: un nivel que podría llamarse lúdico-literal y un nivel alegóricodidáctico" (77). En el primer nivel de lectura, se exige del lector la suscripción del pacto lúdico, a saber, la suspensión de la incredulidad, la aceptación de los hechos narrados como tales, es decir, una lectura literal. Sin embargo, se plantea un problema de verosimilitud pues un relato de corte realista queda alterado por un acontecimiento que aparentemente quebranta las leyes de la naturaleza. La introducción, o mejor dicho, la sugerencia de la presencia de elementos de lo fantástico propone un lector crítico, escéptico, que busca naturalizar lo extraño mediante una explicación racional (tras una serie de lecturas) que logre dar cuenta a la vez de los elementos de verosimilitud apoyándose en toda pista de ambigüedad.

Un rasgo de los textos de Silvina Ocampo que sobresale en este cuento es el de "negarse a la verosimilitud realista y a la vez aceptar lo sobrenatural como una prolija forma del realismo y del verismo” (Pezzoni 17). En este sentido, el cuento ocampeano podría ubicarse en un punto medio entre el relato fantástico y el mágico-realista pues, aunque no construye una cosmovisión que da cuenta con naturalidad de los elementos aparentemente antitéticos, como lo hace el realismo mágico, tampoco se cierra a encontrar la explicación para los hechos extraños sólo mediante una lectura literal, racional. El lector de los cuentos de Ocampo se asemeja más a los personajes kafkianos que “aceptan lo extraordinario sin justificación aparente, con enigmática naturalidad, lo que hace de su reacción un caso más extraño que los mismos sucesos que presencian” (Camayd 86). Es aquí donde el relato elimina cualquier afinidad a la estética mágico- 
realista y se acerca al fantástico. Ese “verismo” no es más que una pista falsa, una pátina que deja al descubierto un mundo donde la exageración y el exceso del deseo reinan.

La solución más adecuada y la que parece proponer el relato se encuentra en la vacilación del lenguaje y su significación en el texto. En este sentido, los relatos de Ocampo exigen un lector crédulo y escéptico, abierto a ambas posibilidades. Una lectura detenida de los detalles del final muestra que la verosimilitud del relato se mantiene al mismo tiempo que no se pone en tela de juicio el concepto de realidad ya que la verosimilitud se instala en los intersticios de significación del texto. El autor propone ciertas pistas y guarda silencio oportunamente para dejar las lecturas, las interpretaciones abiertas, sin privilegiar ninguna.

Según Pezzoni, “Hay algo que retrocede sin cesar, que espera en algún lugar del texto. No es la caricatura ... sino la transmutación. Lo que parece obedecer a la verosimilitud realista se contamina de corrosión, se contagia una y otra vez de ilegalidad ... Se insinúan y hacen llamados los sentidos múltiples, que a la vez no se dejan atrapar” (Pezzoni 11-2). La regresión en el tiempo efectuada en el acto de habla puede interpretarse como una tematización del primitivismo psicológico, entendido como una voluntad de regreso, el deseo de volver a la edad dorada, a un estado de comunión primigenio, donde no existe diferenciación entre el ser y el mundo exterior, según Freud: “originally, the ego includes everything, later it separates off an external world form itself” (84) y por lo tanto, al no diferenciarse las sensaciones, no se comprueba la existencia del dolor que sí plantea un presente adverso. Sin embargo, este sentido debería contrastarse con la significación que le añade el título: “castigo”. En este caso, implica el castigo del interlocutor y un autocastigo para la protagonista, que efectúa su 
autodestrucción, tanto si se lo toma en un sentido literal, donde la palabra recupera el poder de nombrar; o metafórico, donde implica sumirse en el silencio.

Según Pezzoni, el relato expresa el "placer de la venganza: placer de un acto de habla, exaltación del poder de hacer cosas con palabras ... la puesta en escena de los referentes de un lenguaje que ha readquirido su capacidad de nombrar y de hacer” (19). De cierta manera es así, ya que la enunciación de la protagonista "recordar el pasado me mata” (281), parece lograr su cometido, como discutiremos más adelante. Nótese que ese poder de hacer cosas con palabras, de carácter mágico, es expresión de la literalidad del lenguaje infantil donde el signo y el referente son idénticos, palabras y hechos no se diferencian, y confirman el movimiento del relato hacia el principio del tiempo, de la existencia, que se refleja en la narración inversa. Aquí se presenta un elemento que plantea la ambivalencia de la significación última del relato, si es que existe: el regreso al estado primigenio termina en la pérdida de la vida o de la razón -que aunque resultan equivalentes en el estado oceánico o de indiferenciación— suponen un valor negativo; mientras que en el plano lingüístico, el regreso supone la recuperación de un poder perdido con el paso del tiempo, el logos, la palabra creadora, lo cual supone un valor positivo.

La fluidez del lenguaje plasmado en el diálogo y en la evocación contribuye en este plano a configurar la "verosimilitud realista” y una ilusión de naturalidad que propugna una lectura donde llegar a la conclusión de que la protagonista ha logrado efectuar su desintegración mediante el acto de habla no supone ningún esfuerzo. La trascendencia de esta interpretación estaría marcada por el propósito atribuido a la autora de tematizar el poder creador del lenguaje. 
Otra de las lecturas posibles, sin embargo, sería tomar los hechos como metáforas, símbolos de otra realidad. La "muerte" de la protagonista queda en el plano simbólico: la separación del yo de la fuerza absorbente del sentimiento amoroso que atenta contra la autodeterminación. Representaría, entonces, su afirmación como mujer, como individuo, al terminar una relación enfermiza en la que era víctima del hombre.

Es interesante observar que las lecturas no son mutuamente excluyentes sino que se puede lograr una síntesis que proponga una interpretación mucho más rica arraigada en la ambigüedad para así “negarse a la verosimilitud realista y a la vez aceptar lo sobrenatural como una prolija forma del realismo y del verismo" que comentara Pezzoni (17) y darle a los hechos una amplitud de significación. Los elementos comunes que se observan son hombre, mujer, palabra y muerte. Comienzan a cristalizarse tras la declaración de la protagonista: "Ésta es mi vida -me dijo, cerrando los ojos-. Recordar el pasado me mata” seguida por la respuesta del personaje masculino “-¿iTe burlas de mí? -le pregunté” (281) que en pocas palabras pinta el conflicto. No sólo se trata del enfrentamiento hombre-mujer sino de su lucha por tomar la palabra y dominar el lenguaje. Recordemos los intentos de interrumpir el relato de la protagonista y el hecho de que le haga caso omiso de ellos. Aunque el narrador es el personaje masculino, él es quien cuenta la historia, quien abre y cierra el relato, las palabras de la mujer ocupan el mayor espacio narrativo. De esta manera, la autora plantea un espacio abierto donde ambas voces, tanto la masculina como la femenina, puedan expresarse y llegar a oídos del lector. En el plano textual, el recurso de preferencia es el diálogo. Si bien está mediatizado por el narrador, su intrusión es mínima, está más controlada que si hubiera adoptado el estilo indirecto libre. 
El conflicto al que aludíamos está planteado por el dominio de la palabra a lo que debemos agregar su contracara: el silencio. La frase que sigue deja a la pregunta sin respuesta: “No me respondió y apretó los labios: jamás volvió a abrirlos para decirme que me amaba”. En primer lugar, muestra que el narrador busca recuperar el foco: el protagonista reclama el lugar de enunciación de la primera persona, el hombre es la medida de todas las cosas. Los acontecimientos externos y, en este caso, lo que le sucede a la mujer, están planteados en función de sus repercusiones en la vida, en los actos del yo-masculino. Se describen las acciones del otro en tercera persona pero en relación con la primera. Ella (el otro) no me (el yo) respondió. Y más adelante: decirme que me amaba. La reiteración triple del pronombre personal “me”, cuando las reglas gramaticales permiten prescindir de él salvo en el último caso, demuestra ser adrede y produce un efecto léxico y sonoro que refuerza el contrapunto otro-yo. En segundo lugar, ejemplifica la objetivación a la que se somente la protagonista pues, mediante una sinécdoque, queda reducida a un par de labios. No sólo se le niega la identidad sino que se pretende también quitarle el cuerpo, desmembrándolo. Además, el ya reducido elemento se desvaloriza al dejar de cumplir la función que la voz masculina le había asignado: gratificar su ego con las declaraciones de amor. Si quedara alguna duda acerca del egoísmo o la indiferencia que caracterizan al personaje, la frase siguiente la disipa: “no pude llorar”. Ocampo posee una economía de estilo fascinante que se evidencia en estas líneas que la inscribe dentro de la estética común de los escritores del grupo SUR. La yuxtaposición de las frases crea vínculos de significaciones que el lector recoge de manera más o menos consciente y que se completan-complementan entre sí para dirigir la interpretación en una determinada aunque no evidente dirección. 
En las palabras que siguen, se constata la voluntad autorial de presentar en esta historia el conflicto femenino-masculino poniendo en boca del hombre lo que ha sido desde siempre, la visión típica que ha tenido de la mujer: el otro, pero el otro considerado inferior en tanto que es incomprendido e incomprensible. "Como si la contemplara desde la cima de una montaña, la miré, lejana, indefensa, inexpugnable”. En primer lugar, se plantea la relación jerárquica entre el hombre y la mujer, con el lugar de preferencia ocupado, como es de esperar en la sociedad patriarcal, por el hombre. Hasta aquí no hay sorpresa. Tampoco es inesperado el adjetivo “lejana” pues marca la distancia inherente a la dicotomía otro-yo, la cual impide todo intento de comunicación o de comprensión si es que quisiera buscarse uno. Sin embargo, la aparente contradicción de los últimos términos “indefensa” e “inexpugnable” exige un examen con más detenimiento pues su empleo no es arbitrario. En el contexto del relato, “indefensa” bien puede tomarse literalmente como descripción del estado de languidez en que ha quedado la protagonista. Sin embargo, también es expresión de la típica visión masculina de la mujer como “el segundo sexo” o “el sexo débil”, que complementa los demás elementos del discurso patriarcal. El término “inexpugnable” que quiere decir “que no se puede tomar o conquistar por las armas, inaccesible o de acceso muy difícil, que no se deja vencer ni persuadir” (DRAE) es susceptible de leerse como un juicio de valor contra el sujeto que carece de las armas adecuadas, de la fuerza suficiente, de los poderes necesarios para lograr la rendición. Aunque sin duda se puede tomar como una crítica a la mujer, en las líneas de la mujer esquiva, en este caso, con un toque de ironía autorial, entendemos que lo que se subraya es la incapacidad del hombre para comprender a la mujer y que por más que recurra a la fuerza siempre habrá un resquicio que le oponga resistencia. "La abracé 
por última vez y fue como una violación” muestra en este marco, que todo intento de posesión se convertirá en una trasgresión de las normas, en un acto antinatural que acarrea culpa para quien lo perpetra.

Esta lectura está avalada por la frase que sigue en el texto a las comentadas anteriormente: "Su locura era mi único rival”. Uno a uno se van sumando los clichés del discurso masculino sobre la mujer (y se devalúa el elemento surrealista). Ante los intentos infructuosos de dominación o de control, se acude a la naturalización fácil que constituye atribuir lo inexplicable a lo irracional. En el mundo masculino, las conductas femeninas que no se comprenden o no se conforman a las normas establecidas no llevan a una reevaluación de ellas sino a la explicación simplista de que son de alguna forma de neurosis o de histeria, cuyo extremo es la locura. De ese modo, el hombre intenta reafirmarse y borrar las pruebas de su incapacidad de comprensión de la mujer (que en muchos casos obedece a una falta de deseo de hacerlo) pues quedar vencido por un ser “inferior" no es lo mismo que perder la batalla contra una fuerza inmensurable.

Cabe preguntarnos cuál es el motivo de que la autora ponga en boca del personaje masculino los clichés del discurso patriarcal. La primera respuesta sería la obvia: denuncia. En ese nivel, el texto carecería de mayor trascendencia: el significado sería evidente, al igual que el propósito. Sin embargo, Ocampo elude lo fácil mediante la función que juega este discurso dentro de la ejecución técnica de la construcción del relato. La denuncia resulta más sutil y punzante de lo que parece en la lectura superficial o literal. Dicho de otro modo, el hecho de que el relato finalice con la voz masculina no implica el respaldo autorial, su adhesión al orden patriarcal. Todo lo contrario, se trata de la puesta en práctica de una de las estrategias del débil: la simulación. Al darle al 
narrador "la última palabra”, se simula el acatamiento, el darle la razón. Sin embargo, es la autora quien tiene la última palabra pues logra, en conjunto con el lector que capta las claves del texto, construir la lectura irónica que socava la posición masculina y reafirma los planteamientos que se desprenden de la enunciación femenina.

Consecuentemente, podemos afirmar que los clichés vienen a confirmar y a validar el acto vital que supone el suicidio (literal o simbólico) que se lleva a cabo mediante la palabra femenina. La mujer logra mantenerse inexpugnable y aplicar el silencio como castigo. En lo que parece un acto de derrota, se descubre, sin embargo, la afirmación de la identidad propia ante el intento de absorción no mediatizado por el amor.

Por lo expuesto, llegamos a la conclusión de que el texto se presta a la lectura simbólica. En menor grado, la suscripción del pacto lúdico por parte del lector que propugna el relato también lo acerca a esta estética. El lector juega a creer que la palabra recupera su poder de enunciación y que se verifica la muerte de la protagonista. Juega a creer que el tiempo ha transcurrido en sentido inverso para ella y que se ha acelerado para el protagonista masculino. Elige aceptar la imagen del viejo en el espejo como reflejo veraz del personaje que narra la historia. Sin embargo, tanto las palabras finales del narrador como los silencios del texto incitan al mismo tiempo a la búsqueda de otro significado. El lector no acepta la explicación del narrador. Entonces cuestiona su primera interpretación y se lanza a buscar un significado ulterior, para determinar qué es lo que el narrador no le está diciendo, qué cartas oculta. Estas pistas no están puestas por el narrador sino por la autora que hábilmente abre la puerta de la duda. 
Desde el punto de vista lingüístico hay una tematización del poder del lenguaje. Esa desconexión es la que se produce por la pérdida de las tradiciones, de los ritos, de la magia, de ese modo de pensamiento donde signo y referente eran la misma cosa, donde no había abstracciones ni modulaciones que relativizaran los vínculos. Asimismo hace referencia en el plano psicológico al mundo del subconsciente, que originalmente era el estado único e indivisible de la psiquis, y que resurge en el plano consciente a través de un rango de manifestaciones, de las cuales un extremo es la locura, la irracionalidad. Entendemos, entonces, por primitivismo no un sentido único y discreto sino un conglomerado de sentidos que hace alusión en el sentido más amplio a lo primigenio y que se manifiesta en lo cotidiano que plasma Ocampo en sus relatos.

El espejo desfamiliarizante de "Los amantes"

“Los amantes”, incluido en Las invitadas (1961), exhibe también rasgos de la desfamiliarización freudiana. La narración del encuentro entre dos amantes, de entrada busca inscribirse explícitamente en un patrón mítico a través del lenguaje. Los protagonistas no tienen nombre y sólo los denotan los pronombres “él” y “ella”. Sus encuentros esporádicos, se describen como "rituales y ocurrían siempre en invierno" (CCI 392). Asimismo se da una explicación sumaria de en qué consiste: "primeramente compraban masas, después las saboreaban debajo de los árboles” (392). Luego la descripción detallada del ritual avanza paso a paso. El rito se presenta como ansiado, ineludible: “elegían siempre ... la confitería Las Dalias, y un domingo” y para comenzar “se saludaban sin mirarse, ceremoniosamente confusos”; luego “entraron en la confitería como lo hacían siempre” (392). Ocampo dedica una minuciosa descripción de la comida 
de corte metonímico, que aluden a ofrendas y elementos relacionados con los rituales: monumento, frutas, flores, encaje, pedestal de mármol, cofre, joyas, que bordean en el fetiche.

La ubicación de la pareja “junto a un árbol degenerado ... se sentaron sobre el pasto” (392-3), evoca la asociación con una pareja mítica, la del Edén. Luego se describe con sumo detalle la degustación de cada porción que confirma el valor de rito que posee para los personajes:

Simultáneamente, como si cada uno proyectara en el otro sus movimientos (;misterioso y sutil espejo!), tomaron con una mano primeramente, luego con las dos, la tajada de torta con penachos de crema (monumento de los españoles en miniatura), y se la llevaron a la boca. Mascaban al unísono y terminaban de deglutir cada bocado al mismo tiempo. Con idéntica sorprendente armonía se limpiaban los dedos” (énfasis mío).

El énfasis en la sincronización, en la repetición y en la especularidad está marcado por la repetición y por la explícita mención del espejo. Dentro del rito, no hay identidades diversas sino que dos seres se vuelven uno.

El rito descrito en la narración responde a lo que postula Eliade: Human acts... their meaning, their value, are not connected with their crude physical datum but with their property of reproducing a primordial act, of repeating a mythical example. Nutrition is not a simple physiological operation; it renews a communion. Marriage and the collective orgy echo mythical prototypes; they are repeated because they 
were consecrated in the beginning ("in those days," in illo tempore, $a b$ initio) by gods, ancestors, or heroes. (65)

La conexión nuevamente se hace explícita en el texto: “La repetición de estos movimientos los comunicaba con la eternidad” (394). Es decir, lograrían, a través del rito, trascender las barreras de la comunicación oral — “Todas las personas que no se ven a menudo, no saben qué decirse; esto es cierto” (392)—y participar de una comunión trascendente porque es repetición de un acto mítico y por ende, sagrado, desde el comienzo de los tiempos.

Sin embargo, hay algo sospechoso en el cuidado que el narrador pone en explicitar los valores míticos y rituales del encuentro. En la descripción de la ingestión ritual, contrasta con la seriedad que se le atribuye al rito -"Hasta que pudieran terminar el contenido de la bandejita...ninguna sonrisa animaría aquellos labios armoniosos”(392)— una interrupción, una distracción de los participantes:

Ella, de vez en cuando, se volvía para ver pasar un automóvil más valioso que los otros por su excesivo olor a nafta y por su tamaño, o levantaba la cabeza para mirar una paloma, símbolo de amor, que revoloteaba pesadamente entre las ramas. Él miraba hacia adelante, pero tal vez paladeaba con menos conciencia que ella el gusto de esos manjares (393). Se comprueba también por el contraste de actos que existe una vez terminada la degustación: “Relamiéndose los labios osaron esbozar algún tímido diálogo” (394). Ahora hablan pero se reinstala la timidez y el diálogo, en apariencia, trivial alude a imágenes de muerte y relaciones frustradas. Asimismo, una pista que parecería insignificante y bien se pudo pasar por alto, cobra significado y confirma las sospechas: 
el árbol bajo el cual se recuestan se describe como “degenerado” (392). En el mismo tenor, la paloma "símbolo de amor" (la frase resulta extraña sin el artículo determinante “el”: “del” que haría alusión al valor universal) revolotea "pesadamente” (393). Es notable que en ningún momento se hace alusión al sentimiento que los une.

Hacia el final, el narrador relata que: “sonrieron por primera vez, pues tenían la boca libre de alimentos y de palabras” (394). La frase da a entender que el ritual (ahora calificado de simples “alimentos”) y la conversación (tan solo "palabras” que ocupan lugar en la boca) son los obstáculos para la intimidad física, que entonces se presenta como el verdadero propósito del encuentro, pero desprovisto de la trascendencia mítica que pudiera haber tenido (Nótese la identidad placer gastronómico, placer erótico como ejemplos del principio del placer). El narrador termina el relato con la comprensión por parte de ambos de que “el amor repetiría sus actos” (394) empleando una frase eufemística que pone la distancia de lo innombrable, a la vez que lo reduce a un ejercicio mecánico; y da la clave “la esperanza, con alas frívolas, cada vez más remota”, que reproduce metonímicamente la imagen del ave y la asociación con la paloma. La última frase, “la alejaría del matrimonio” (394), en este contexto carece de asociación con convencionalismos sociales. Por el contraste que se establece entre la solemnidad y minuciosidad de la descripción del ritual, y los contrapuntos que ofrecen la conducta de los personajes, entendemos que con la palabra "matrimonio" el narrador hace referencia a la unión eterna, trascendente, primigenia como la que expresa el rito. Una unión que se aleja, que resulta imposible, por la caída que supone la falta de comunicación real entre los seres, que quizás en la repetición del rito “mecánicamente” conjuraron los valores 
negativos de la pareja mítica: la pareja edénica pierde la oportunidad de gozar de una comunión a todo nivel y todo intento por recrearla correrá la misma suerte.

El análisis revela dos posibilidades que son contradictorias pero no excluyentes. Por un lado, está la interpretación de la historia como un ritual que reactualiza los hechos míticos primigenios y que al realizarse en lo cotidiano, permite escapar de la monotonía y participar de lo eterno, desafiando sin prejuicios, los convencionalismos sociales que sólo atan. Por otro lado, se ofrece la interpretación del desvirtuamiento del ritual por su ejecución mecánica, síntoma de la degeneración que supone la edad moderna, por su aislamiento, falta de comunicación, por su abandono de las tradiciones, de los valores trascendentales como el amor y de la autenticidad en las relaciones humanas. A este propósito, Pezzoni señala:

Toda vertiente de los relatos de Silvina Ocampo descubre las huellas del orden remoto en lo cotidiano. Fugaces apariciones de lo mágico, lo maravilloso, pero siempre ofrecido como un don inservible o destinado a un empleo que no otorgará a su poseedor el menor poder sobre el mundo. Nostalgia o deseo no se sacian con el cálculo, la maniobra. Esta denuncia del don sobrenatural inservible -burlona versión de lo unheimliche freudiano, de la inquietud ante la posibilidad de que lo neutralizado por la superstición o museificado en el mito pueda volverse real— se da muchas veces en el interior mismo del lenguaje. (18)

Dadas las dos posibilidades, no es posible garantizar la preponderancia de una o la otra ya que el propio texto no se presta a ello y parece preferir la indeterminación. Hay un rasgo primitivista que le da una atmósfera enrarecida. Se comprueba a nivel textual, por 
todas las alusiones al rito mencionadas, y también a nivel interpretativo, a través de la primera posibilidad, que se traduce en un anhelo por esa trascendencia original, primigenia.

Según lo expuesto, podemos afirmar que la ambigüedad, lo inesperado se instala en lo cotidiano, como señala Pezzoni, para "negarse a la verosimilitud realista y a la vez aceptar lo sobrenatural como una prolija forma del realismo y del verismo” (17) y darle a los relatos esa pluralidad de significación que los hace tan difíciles de clasificar y a la vez da cuenta de la atracción que generan. Así, el lector entra en ese juego familiar que propone Ocampo de lo conocido que se desvanece, lo olvidado que es reconocible. Se trata de que descubra el juego, reconozca la idea detrás del disfraz, recuerde lo olvidado y restablezca la conexión perdida o cuando menos, de obligarlo a que lo intente.

Por otra parte, no puede dejarse de lado la resonancia que el tema del doble tiene en este cuento a nivel temático e interpretativo. Éste se presentaría en un sentido inverso al desdoblamiento del personaje, de uno a dos, y, en cambio, sería un movimiento de dos a uno. La pareja se presenta como dos entidades cuya identidad individual se diluye para ser proyecciones de una sola carente de autonomía, de autodeterminación. La repetición de un rito vacío es expresión del vacío de su ser. Según la teoría de Bataille sobre el erotismo, los individuos son seres discontinuos y sólo la muerte tiene el sentido de la continuidad del ser. (9) Sin embargo, "el erotismo de los cuerpos tiene de todas maneras algo pesado, algo siniestro. Preserva la discontinuidad individual, y siempre actúa en el sentido de un egoísmo cínico” pues en él comienza el terreno del hábito y del egoísmo de a dos. (14) 
A partir de lo expuesto hasta este punto podemos recoger las primeras observaciones acerca de las estrategias desestabilizadoras que Ocampo emplea en la construcción de sus cuentos tomando elementos y motivos del género fantástico pero dándoles la vuelta según su capricho. Así, configura un estilo propio que coquetea con las convenciones de género lo suficiente para volver las pistas reconocibles, pero manteniendo una cierta distancia creativa y autonomía combinatoria que le garantice libertad. Esta estrategia se mantiene como una constante en su obra, incluso al tratar otros temas y motivos afines, aunque con distinto énfasis, aplicada por ejemplo a la exploración de la identidad del sujeto, tal como veremos en el próximo capítulo. 
CAPÍTULO 3 - La exploración de los andamios de la identidad

“El día en que me muera... Iré corriendo por la plaza San Marco,[sic] por todas las edades, y no me reconoceré en ningún espejo, por mucho que me busque, y que me

$$
\text { busquen.” Silvina Ocampo (“Anotaciones”) }
$$

Es notable el espacio que Ocampo dedica en su narrativa a la exploración de la identidad del sujeto. Sin embargo, es interesante observar que lo hace desde su particular estilo, creando formas nuevas que distan mucho de las tradicionales de la "narración psicológica” y se apartan de toda voluntad mimética. Recordemos que Ocampo publica sus primeros cuentos en un momento en que la narrativa adolecía de una debilidad de la trama, como lo señala en el prólogo a la Antología de la literatura fantástica. Desde un relato “fantástico" (entendido siempre en las coordenadas ocampeanas), hasta un poema en prosa de versificación libre o bien un fragmento de profunda resonancias líricas: todo le sirve para entrar en materia. Esto supone un ejercicio y un estímulo para el lector también pues, constantemente, juega con sus expectativas: el lector nunca sabe con qué se va a encontrar al abrir un cuento de Silvina Ocampo. Confesiones y confidencias, recuerdos de hechos traumáticos en secuencias oníricas o retrospectivas, por nombrar algunos, son recursos de los que echa mano. En los siguientes relatos que analizaremos, relatos que se desarrollan en los espacios inestables de la memoria, veremos cómo Ocampo lo logra desde distintas propuestas formales que evolucionan en el transcurso de su carrera literaria. Los cuentos siguientes tematizan algunas constantes de la obra de Ocampo:1) La memoria como invención. 2) La memoria como espejo en la construcción 
de la identidad. 3) La imposibilidad de encontrar la unidad del sujeto en la imagen del espejo: el significado es siempre diferido.

Para Lacan, el paso del imaginario al orden simbólico se produce a través del paso por la etapa del espejo, el cual revela al ser, que hasta ese entonces se consideraba un todo, su indefensión e imposibilidad de coordinarse, angustia que se resuelve al ingresar al orden simbólico a partir de la recepción del habla. ${ }^{18}$ Más que un momento definitivo, como en sus primeras conceptualizaciones, Lacan lo caracteriza luego como un proceso, un ir y venir constante que elude los esencialismos y difiere el sentido. Puede decirse, entonces que el ingreso al orden simbólico no es determinante ni definitivo sino un proceso en construcción cuyo significado se difiere.

En consonancia con esta noción de la constitución de la identidad, Ocampo traza un planteamiento desde su obra artística que conjuga la escritura y la identidad como signos cuyo significado queda diferido. En "La calle Sarandí” un hecho traumático socava las bases de la memoria, impidiendo la toma de conciencia por parte de la protagonista de su paso al orden simbólico. Esto podría ilustrarse como la imposibilidad de encontrar el espejo, la ausencia del espejo y la invención del espejo como parte de un proceso necesario. En "Voz en el teléfono”, la memoria funciona como un espejo que devuelve al protagonista no sólo los hechos de su niñez que forman su identidad y que él asume como propios, sino también otros detalles que suben a la superficie de la memoria a través de la evocación y reactualizan los anteriores sin que el narrador sea plenamente

\footnotetext{
${ }^{18}$ Derrida denominará al orden simbólico “logocéntrico”.
} 
consciente de ellos (ve la imagen reflejada en el espejo de la memoria, pero se concentra en ciertos detalles mientras que otros que quedan fuera de foco reclaman su espacio).

En este punto, conviene trascribir por su utilidad, la voz “espejo” según la define Juan Eduardo Cirlot en su Diccionario de símbolos:

El mismo carácter del espejo, la variabilidad temporal y existencial de su función, explican su sentido esencial y a la vez la diversidad de conexiones significativas del objeto. Se ha dicho que es un símbolo de la imaginación --o de la conciencia-- como capacitada para reproducir los reflejos del mundo visible en su realidad formal. Se ha relacionado el espejo con el pensamiento, en cuanto éste --según Scheler y otros filósofos-- es el órgano de autocontemplación y reflejo del universo. Este sentido conecta el simbolismo del espejo con el del agua reflejante y el mito de Narciso, apareciendo el cosmos como un inmenso Narciso que se ve a sí mismo reflejado en la humana conciencia. Ahora bien, el mundo, como discontinuidad afectada por la ley del cambio y de la sustitución, es el que proyecta ese sentido negativo en parte, calidoscópico, de aparecer y desaparecer, que refleja el espejo. Por esto, desde la Antigüedad el espejo es visto con un sentimiento ambivalente. Es una lámina que reproduce las imágenes y en cierta manera las contiene y las absorbe. Aparece con frecuencia en leyendas y cuentos folklóricos dotado de carácter mágico, mera hipertrofia de su cualidad fundamental. Sirve entonces para suscitar apariciones, devolviendo las imágenes que aceptara en el pasado o para 
anular distancias reflejando lo que un día estuvo frente a él y ahora se halla en la lejanía. Esta variabilidad del espejo "ausente" al espejo "poblado" le da una suerte de fases y por ello, como el abanico, está relacionado con la luna, siendo atributo femenino. Además es lunar el espejo por su condición reflejante y pasiva, pues recibe las imágenes como la luna la luz del sol (8). Entre los primitivos, es también --y en esto muestra con claridad su pertenencia a la esfera lunar-- símbolo de la multiplicidad del alma, de su movilidad y adaptación a los objetos que la visitan y retienen su interés. Aparece a veces, en los mitos, como puerta por la cual el alma puede disociarse y "pasar" al otro lado, tema éste retenido por Lewis Carroll en Alicia. Esto solo puede explicar la costumbre de cubrir los espejos o ponerlos vueltos de cara a la pared en determinadas ocasiones, en especial cuando alguien muere en la casa (21). Todo lo dicho no agota el complejo simbolismo del espejo. Como el eco, es símbolo de los gemelos (tesis y antítesis) y símbolo específico del mar de llamas (vida como enfermedad) $(50,51)$. Para Loeffler, los espejos son símbolos mágicos de la memoria inconsciente (como los palacios de cristal) (38). Un sentido particularizado poseen los espejos de mano, emblemas de la verdad (4) y, en China, dotados de cualidad alegórica a la felicidad conyugal y de poder contra las influencias diabólicas (5). Leyendas chinas hablan de los "animales de los espejos". (200-1) 
Estos simbolismos, particularmente los referidos al espejo como elemento de adivinación y como puerta de acceso a otros mundos, están presentes en los cuentos de Silvina Ocampo, quien ha sabido explotar la riqueza de los significados en referencias y elementos temáticos. La alusión a Alicia es expresa en "Cornelia frente al espejo" al igual que la costumbre de cubrir los espejos. Desde el punto de vista de la interpretación de los textos, el espejo se convierte en una metáfora útil en "La calle Sarandí” y “Voz en el teléfono”; en el primer caso, como metáfora de la memoria, y en el segundo, como metáfora de la escritura. Estos cuentos son apenas tres ejemplos de la recurrencia del espejo en la narrativa de Ocampo, siempre referidos al autoconocimiento y a la construcción de la identidad.

El cuarto de la memoria en "La calle Sarandí”

"It is a poor sort of memory that only works backwards, after all” Lewis Carroll’s White Queen - Through the Looking Glass.

Incluido en el primer volumen de cuentos, Viaje Olvidado (1937), "La calle Sarandí” sigue la línea temática de la narración que le da título al contario: la exploración de las primeras experiencias de la niñez a través de la mirada del niño, atravesando los espacios inestables de la memoria. El motivo del viaje, de amplio tratamiento en la literatura de todos los tiempos, cobra aquí el sentido de introspección y retrospección. Es decir, se trata de un movimiento sobre un plano espacial desde un punto representado por el presente de la enunciación hacia adentro y hacia atrás, a distintos puntos anteriores pero no necesariamente conectados en forma lineal. Al emplear la palabra "calle”, el 
título del cuento denota no sólo la denominación de un lugar, sino que, unido a la connotación de dirección, movimiento y tránsito, destaca la idea del espacio y a través de una función de anclaje refuerza la idea de la memoria como lugar. El lugar de los hechos es el lugar de la memoria, pero no se trata de un lugar al que se puede volver sino de un lugar más complejo: un sitio del que nunca se ha salido. Así, pasado y presente, recuerdos y acontecimientos, fluyen como olas sobre la conciencia que narra: conviven y configuran en un estado de atemporalidad, transformando la isotopía espacio-temporal del relato y del universo narrado.

La acción narrativa transcurre en la conciencia del personaje, una mujer que no tiene nombre ni edad definida. En este sentido, emparenta con una modalidad de la narración antirrealista de corte psicológico y existencialista. La influencia de la fenomenología en la literatura y sobre todo la de ese período de la primera mitad del siglo XX es bien conocida ${ }^{19}$. A partir de sus postulados, la realidad independiente no existe sino que es todo percepción. Nada existe fuera de la conciencia que lo percibe pues no hay manera de conocer sino a través de la conciencia. Así, se renuncia a cualquier intento de reflejar la realidad en la obra literaria. Lo que se plasma es una transcripción de la experiencia de la conciencia. Desde ese planteamiento, es factible presentar los hechos en un modo impresionista, podría decirse, incluso “surreal” en el sentido de la estilización de las imágenes.

\footnotetext{
${ }^{19}$ Uno de los ejemplos más paradigmáticos de la literatura fenomenológica en el género novela es “El pozo" (1939) del escritor uruguayo Juan Carlos Onetti (1909-1994), contemporáneo de Ocampo. Allí se narra el paso por el plano de la conciencia de impresiones, recuerdos, ensoñaciones de la voz narrativa sin la posibilidad de refrendamiento empírico para el lector. Otro detalle de interés es tema del deseo como constituyente de la conciencia y la identidad, expresado en la pulsión antitética de eros y thanatos, a partir de la presencia indiferenciada del recuerdo o la evocación de la mujer objeto del deseo y víctima de la agresión sexual, que reaparece tanto como figura deseada y amenazante.
} 
Al personaje femenino, cuyo nombre no se menciona, le resulta imposible olvidar los hechos traumáticos que marcaron su niñez y queda paralizada en un estado de ensoñación permanente. “No tengo el recuerdo de otras tardes más que de esas tardes de otoño que han quedado presas tapándome las otras.” (55) Nótese el recorte, la selección a partir del contraste entre “esas tardes” versus “las otras” y las interacción de los vocablos “presas” y “tapadas”. La distorsión de un punto en el tiempo y el espacio se opera en el lenguaje a través del uso del plural con la connotación de lo indefinido y de la repetición. Recuerda en detalle espacios, momentos, personas pero la falta de correlación entre unos y otros, los saltos de la memoria, así como la focalización excesiva en detalles minúsculos con respecto al arco de la existencia hablan de una percepción alterada.

Los jardines y las casas adquirían aspectos de mudanza, había invisibles baúles flotando en el aire y presencias de forros blancos empezaban ya a nacer sobre los muebles obscuros de los cuartos. Solamente las casas más modestas se salvaban de las despedidas invernales. (55)

La visión es casi surreal: nótese la selección de imágenes “baúles flotando”, “presencias”, “nacer” que subrayan la falta de agencia humana. La descripción de una tarde vale para todas connotando de nuevo la idea de repetición y homogeneización desde el punto de vista del recuerdo, reforzado por los tiempos verbales en modo imperfecto: "Eran tardes frescas y los últimos rayos del sol amarillo, de este mismo rosado-amarillo, envolvían los árboles de la calle Sarandí, cuando yo era chica y me mandaban al almacén a comprar arroz, azúcar o sal”. (55) 
Del mismo modo, que podría definirse como metonímico, se realiza la narración del hecho traumático de la violación perpetrada por el vecino en “esas tardes”. Al hecho no se alude en forma directa ni explícita, sino que Ocampo va creando una atmósfera de anticipación y amenaza en la que se desencadenará la tragedia inevitable, a través de la dosificación de imágenes de connotaciones negativas, mezcladas con detalles descriptivos que resultan antitéticos: "El miedo de perder algo me cerraba las manos herméticamente sobre las hojas que arrancaba de los cercos; al cabo de un rato creía llevar un mensaje misterioso, una fortuna en esa hoja arrugada y con olor a pasto dentro del calor de mi mano” (55 el énfasis es mío). La mención del miedo a perder algo, las manos cerradas en contraste con la imagen olfativa del olor a pasto y el calor de la mano hacen de lo que podría ser un simple entretenimiento de niños como el juntar hojas, el inventarse una historia haciendo de cuenta que algo trivial como una hoja puede ser una fortuna, se perciba como fuera de lugar y abra la puerta a un sentido de inquietud que será confirmado por el contenido del enunciado que sigue.

En la mitad del trayecto, de la casa donde vivíamos al almacén, un hombre se asomaba, siempre en mangas de camisa y decía palabras pegajosas, persiguiendo mis piernas desnudas con una ramita de sauce, de espantar mosquitos. Ese hombre formaba parte de las casas, estaba siempre allí como un escalón o como una reja. A veces yo doblaba por otro camino dando una vuelta larguísima por el borde del río, pero las crecientes me impedían muchas veces pasar, y el camino directo se volvía inevitable. (55 el énfasis es mío) 
Otro estigma en la protagonista es el constante abuso al que es sometida por parte de su familia. Al ser la menor y ser mujer, es tratada como una sirvienta, o bien una esclava. Se establece una doble subyugación: por cuestión de género y por cuestión de edad. Esa dicotomía femenino-masculino y menores-mayores, en la cual los segundos términos siempre llevan las de ganar, no encuentra resolución sino en el escape que supone la muerte. La protagonista saldrá entonces del cuartito de sus manos. En su estudio del trauma, Freud explica la interacción entre el trauma y la memoria:

The one most commonly affected by psychological trauma is long-term memory. Missing memories, changes to memory, intensified memories all are cases of manipulations of long-term memory. The theory/reality of repressed memory is the idea that an event is so traumatic, that the memory was not forgotten in the traditional sense, or kept secret in shame or fear, but removed from the conscious mind, still present in the longterm memory but hidden from the patient's knowledge.

Intrusive thoughts are defined as unwelcome, involuntary thoughts, images or unpleasant ideas that may become obsessions, are upsetting or distressing, and can be difficult to be free of and manage. In patients who have suffered from traumatic events, especially those with post-traumatic stress disorder, depression or obsessive-compulsive disorder, the thoughts are not as easy to ignore and can become troubling and severe. These thoughts are not typically acted on; the obsession of the thoughts usually comes from intense guilt, shame or anxiety relating to the fact that the 
patient is having the thoughts to begin with so they are unlikely to actually act on things they feel so badly about. In trauma patients, the intrusive thoughts are typically memories from traumatic experiences that come at unexpected and unwanted times. The primary difference from other intrusive thoughts sufferers is that the memories are real rather than imagined. (sp)

Esta explicación da cuenta del fenómeno que vive la protagonista no identificada de "La calle Sarandí”. La aparición de los recuerdos no en tanto a memorias sino a vivencias del presente narrativo provoca una dislocación del tiempo y del espacio y la consiguiente desarticulación de identidad del sujeto. La imposibilidad de reconocerse en el espejo y la falta de reconocimiento de la voz del "hijo" aluden a una falta de continuidad de la memoria de origen en la experiencia traumática y la sumisión en un constante estado de ensoñación sin ningún tipo de aliciente o mediación de placer. Según lo apunta SchmidtCruz:

In Beyond the Pleasure Principle, Freud theorizes that the compulsion to repeat traumatic events or painful emotions is greater than the avoidance of unpleasure. The subject deliberately places him or herself in a distressing situation acting out an earlier traumatic experience that may have been repressed or not fully understood. (Schmidt-Cruz 81)

Éste es uno de los cuentos que desmitifican el mundo de la infancia a la vez que ilustran lo perdurable de las memorias de este momento en la trayectoria vital. La distorsión del tiempo y la memoria es una de las preocupaciones de la autora y motor de 
la escritura, como se ha comentado, es el intento de descifrar "una imagen indescifrable, que perdura de la infancia” (Grondona 175), sobre todo, cuando se trata de imágenes cargadas de dolor, como en este caso.

En la dislocación del tiempo viene a colación la cita de Chesterton que Ocampo corrige: "La única manera de recordar un lugar para siempre es vivir en ese lugar por una hora; y la única manera de vivir en un lugar por una hora es olvidar el lugar por una hora.” (cit. en Grondona 175) Este principio parece operar sobre la conciencia narrativa en "La calle Sarandí”, aunque muy a su pesar. La rectificación de Ocampo: “Ante todo pienso que Chesterton se equivocó. El tiempo no es tan simple. Para siempre es una hora y la única manera de vivir en un lugar por una hora es vivir para siempre en él” (énfasis en el original 175) La imagen de la infancia perdura por ser un enigma plantado en una encrucijada espacio-temporal. Si la persistencia de la memoria aplica al recuerdo infeliz, la única manera de intentar descifrarlo, desentrañarlo, neutralizarlo, independientemente del éxito, es a través de la escritura. Así lo entiende Ocampo de niña, según lo evoca en la citada entrevista: "Descubrí que mis composiciones..., a medida que las escribía sobre la página fría y blanca, volvía maravilloso lo que era trágico, horrible y tedioso.” (175) El cuento es, entonces, el vehículo de escape para el personaje con la autora al volante.

El espejo de la escritura en "Voz en el teléfono"

“Ahora vemos por espejo, oscuramente...” (1 Cor. 13:12 - La Biblia)

El cuento "Voz en el teléfono”, que integra el volumen de narraciones La furia y otros cuentos, aparece en 1959. El volumen se publica casi once años después de Autobiografía de Irene (1948), la segunda colección de narraciones, compuesta por cinco 
cuentos largos, o bien, podría hablarse de novelas cortas. Este cuento se inserta en la etapa intermedia de la obra cuentística de Ocampo de acuerdo con el estudio y la clasificación realizados por Graciela Tomasini. Según Tomasini, esta etapa se caracteriza por un despegue respecto de la inicial y en ella se comienza a afianzar el estilo de la escritora. Por otro lado, cimenta la percepción de este cuento como paradigmático del estilo ocampeano, el hecho de que "Voz en el teléfono” fue uno de los cuentos seleccionados para integrar la colección que publicó en inglés Penguin Classics en 1988 bajo el título Leopoldina's Dream con traducciones de Daniel Balderston. ${ }^{20}$

El cuento narra la historia del incendio intencional provocado durante la fiesta de cumpleaños del protagonista, Fernando, en el cual mueren su madre y presumiblemente las mujeres que la acompañaban, entre ellas, las madres de algunos de los invitados. El encuadre del relato, que prescinde de todo recurso introductorio, plantea para el lector una dinámica de la lectura equivalente a la del fisgón, de la escucha a hurtadillas pues sin contar con tiempo para reaccionar, se topa con la acción en media res que despierta su curiosidad y capta su atención. Además de constituir una novedad formal, ya característica del estilo ocampeano, le imparte dinamismo a la estructura, la aliviana, ganando en economía discursiva, a fin de poder explayarse, detenerse a gusto en otros detalles más importantes para el argumento y la trama. Judith Podlubne afirma que "Voz en el teléfono” como otros tantos cuentos de Ocampo es “la ocasión de que una voz,

\footnotetext{
${ }^{20}$ Es en ese volumen que aparece una introducción de la autora escrita originalmetne en inglés en la cual se explaya sobre su relación con la escritura, la música y la pintura, en particular, con los móviles que la llevan a escribir. Dicho texto fue luego traducido al español por Manuel Montes y recogido en el dossier sobre Silvina Ocampo que Reina Roffé coordinó para el número 622 de Cuadernos Hispanoamericanos en 2002.
} 
interesada en revelar sus secretos personales, muestre sus inclinaciones íntimas. Las voces se distinguen por una abierta disposición a hablar de sí mismas”. (101)

Teniendo al personaje como narrador, el relato acorta la distancia narrativa y se focaliza en su punto de vista que, como se verá, alterna entre el del adulto y el del niño en el momento en que la narración se remonta a los hechos de la niñez.

No, no me invites a casa de tus sobrinos. Las fiestas infantiles me entristecen. Te parecerá una macana. Ayer te enojaste porque no quise encender tu cigarrillo. Todo está relacionado. ¿Que estoy loco? Tal vez. Ya que nunca puedo verte, terminaré por explicar las cosas por teléfono. ¿Qué cosas? La historia de los fósforos. Detesto el teléfono. Sí. Ya sé que te encanta, pero a mí me hubiera gustado contarte todo en el auto, o saliendo del cine, o en la confitería. Tengo que remontarme a los días de mi infancia. (OCI 271)

Ese primer párrafo es determinante para ubicar al lector en el contexto a partir de un mínimo de pistas integradas a la situación. La habilidad de Ocampo reside en la forma sutil de guiar la lectura sin recurrir a los típicos mecanismos narrativos del cuento tradicional (introducción, escena, descripción, etc.). El personaje se dirige a alguien en segunda persona: “No, no me invites... Te parecerá una macana” por lo cual, la primera impresión del lector es que se está dirigiendo a él en el estilo de los relatos que pretenden crear la ilusión de que el lector participa en la historia. A primera vista, no sería éste el caso pues los siguientes enunciados configuran una segunda persona intradiegética, si bien ésta no interviene en el texto sino por mediación de las alusiones del narrador, que 
en sí, abre la puerta a otra problemática en torno a su significación. De una simplicidad engañosa, este recurso constituye uno de los elementos que le aportan riqueza al texto pues le permite a la autora presentar desde distintas perspectivas la información para que el lector complete la historia y le aporte significado.

La identidad del “interlocutor” de la narración se reconstruye a partir de los enunciados de la voz narrativa en los que se alude a experiencias compartidas, gustos, opiniones, hechos anteriores al presente narrativo. Todo hace suponer que se trata de una mujer, la novia del protagonista-narrador. La imposibilidad de verificar la información suministrada pone de relieve otro de los mecanismos que entran en juego en la estructura: la autoridad del texto que de suyo traza una de las coordenadas de interpretación para el lector. La voz narrativa es singular y simula dar la palabra al interlocutor para crear una idea de pluralidad de voces y mayor credibilidad, pero esto es sólo un monólogo disfrazado. Cada “interjección” del interlocutor se transforma así en un mecanismo que impulsa el discurso del narrador. Sólo hay una voz que enuncia bajo una máscara de pluralidad. Se trata de una manera eficaz del yo para negar la palabra al otro, ese otro que se inscribe en el discurso sólo en la medida en que sirve de escucha al enunciante, lo cual exhibe una despareja relación de poder. Una estrategia similar de toma de palabra para anular al otro se empleó en "El castigo" con la diferencia de que, en dicho caso, para el enunciante sí se verifica la anulación del otro y la propia. En "Voz en el teléfono" se anula la voz del otro subrepticiamente, sirviéndose de ella para afirmar la propia y explayarse en su confidencia. 
Planteado el “problema” en el primer párrafo, el lector asistirá al intento del personaje de dar una explicación, una justificación para sus actos, de normalizar lo que le "parecerá una locura”. El relato deja entrever el problema que subyace a la expresa fobia a los fósforos o a las fiestas infantiles por parte del adulto: un hecho traumático de la niñez (“Tengo que remontarme a los días de mi infancia”). El primer elemento que se destaca de la infancia es la voz de la madre con una admonición: “-Fernando, si jugás con fósforos, vas a quemar la casa -me decía mamá, o bien-: Toda la casa va a quedar reducida a un montoncito de cenizas -o bien-: Volaremos como fuegos de artificio.” Para el niño, como se ve en "Viaje olvidado", no hay distancia entre el significado y el significante. La palabra tiene el poder de nombrar.

La vuelta al discurso del adulto por la intervención del interlocutor marca el contraste de la percepción del grande. “¿Te parece natural? A mí también, pero todo eso me inducía a tocar fósforos, a acariciarlos, a tratar de encenderlos, a vivir por ellos.” (271) Lo natural es que los adultos les prohíban a los niños ciertas conductas peligrosas. El siguiente intercambio sirve de contraste: “¿Te sucedía lo mismo con las gomas de borrar? Pero no te prohibían tocarlas. Las gomas de borrar no queman. ¿Las comías? Ésa es otra cosa. Los recuerdos de mis cuatro años tiemblan como iluminados por fósforos.” (énfasis mío 271). Pizarnik comenta magistralmente este cuento:

Además de nouveau riche de sus cuatro años, Fernando es adorador de fósforos, gracias al "tercero" y a su madre, la que no cesa de plantearle un problema sobre la causalidad: Fernando, si juegas con fósforos, vas a quemar la casa. Y Fernando, como los niños chicos, y los científicos 
grandes, necesita verificar la dosis de verdad que puede encerrar un problema.

Así, la fiesta de cumpleaños se vuelve apoteósica o, más modestamente, traumática: Fernando juega con fósforos y quema la casa. En cuanto a las madres, mueren por fuego, naturalmente. (92)

La profunda desprotección afectiva producto del descuido que sufre el niño, unido a la soledad en que queda sumido luego de que las figuras relevantes en su mundo lo abandonan (el cocinero y la madre) desencadenan el conflicto interior del personaje aunque éste no sea consciente de ello. En las breves páginas de "Voz en el teléfono”, Ocampo presenta un análisis psicológico de su personaje en primera persona. La selección de la información es clave en este caso al igual que la caracterización y los detalles que se incluyen. Ocampo no deja nada al azar. El conflicto entre los sirvientes y los amos, divididos en bandos rivales, por ejemplo, es un detalle que el adulto recupera de sus recuerdos infantiles. El recorte de la información es notable pues no hay correlación entre lo evocado y la experiencia de un niño de cuatro años. Sin duda es el adulto quien, desde el punto de vista privilegiado de los años y la experiencia, logra extraer ese detalle y “procesarlo” en su evocación. Sin embargo, he ahí una paradoja: el adulto destaca una experiencia de su niñez pero al contarla, la voz narrativa adopta el estilo propio del punto de vista de niño. El adulto que enuncia cambia de registro de manera "inconsciente” al remontarse en el tiempo al lugar de los hechos narrados. El pasado se actualiza con la mirada del adulto pero sin perder la voz del niño. 
Otro ejemplo de esta particular amalgama narrativa es la minuciosa descripción de los espacios de la casa y de los objetos de las vitrinas que le llaman tanto la atención al niño. Como dijimos, cada elección autorial está cuidadosamente atada a la estrategia narrativa tendiente a lograr el efecto deseado. El narrador adulto vuelve la mirada sobre la casa paterna donde transcurrió su niñez y que ya no existe. Asimismo, hace un inventario de los artículos decorativos de valor que ocupaban las vitrinas y que, durante la fiesta, son reemplazados por juguetes y recuerdos para niños, hecho que, como se verá más adelante, unido a la transformación del espacio con motivo de la fiesta, es motivo de desagrado para el niño. Estos detalles giran en torno al eje de la carencia que articula el relato.

Uno de los recursos predominantes en la obra de Ocampo, y del cual este cuento es un ejemplo, es su trabajo de focalización poco frecuente en la narrativa de la época: presentar el punto de vista infantil en contraste con el punto de vista adulto que presupone el narrador. Esto se ve particularmente en la evocación de los recuerdos en torno a las experiencias de carácter erótico. El punto de vista se acota a los saberes y a las impresiones acordes con la edad del niño que, de suyo, son incompletos. Es por eso que el lenguaje falla y el personaje acude a comparaciones que responden a su limitada experiencia. Uno de los ejemplos que mejor ilustra este concepto es la descripción del “juego” de las señoras en el cuartito:

Las señoras reían tanto que apenas comprendía yo las palabras que pronunciaban. Hablaban de corpiños, y una de ellas se desabotonó la blusa hasta la cintura para mostrar el que llevaba puesto: era transparente 
como una media de Navidad, pensé que tendría algún juguete y sentí

deseos de meter la mano adentro. Hablaron de medidas: resultó que se trataba de un juego. (273 el énfasis es mío)

Esta imagen es significativa, primero, en cuanto denota la reacción ante el descubrimiento del propio deseo y el despertar de la sexualidad desde el punto de vista del niño que no cuenta con los conceptos para darle nombre. En segunda instancia, en un nivel simbólico, es la tematización de la dinámica del complejo de Edipo (según Freud y Lacan) esta vez, trasladada de la Madre a la Mujer. La interferencia autorial es mínima: “acentuando de nuevo el efecto de lo narrado por contraste con las limitaciones del narrador” (Fernández 27) ${ }^{21}$. Como todos los hechos relatados por narradores ingenuos, es el lector el que capta y, desde su bagaje de saberes y experiencias, rellena el espacio en blanco de la significación y completa el sentido de lo que el narrador o el personaje no parecen comprender.

[L]a mirada infantil transgrede los límites de la estructura tradicional y los descubre. ... Los niños observan el mundo sin los prejuicios propios del mundo de los adultos, representan la inocencia. ... Los personajes infantiles son a menudo víctimas de la crueldad de los adultos, pero también manifiestan comportamientos crueles. La ambigüedad se mantiene siempre con respecto a la responsabilidad y la conciencia de los niños sobre sus actos crueles. (Suárez Hernán 373)

\footnotetext{
${ }^{21}$ Fernández, Teodosio. "Del lado del misterio: los relatos de Silvina Ocampo" Anales de literatura española 16 (2003): 5-38.
} 
Esta oscilación del lector es factible gracias a que está ubicado en una posición privilegiada, en comparación con la del protagonista, es decir, extratextual, que le permite evaluar la distancia o acercamiento de los sistemas axiológicos y ontológicos no sólo del mundo narrado sino del contexto empírico. Se evidencia así el juego de significación del texto, a través de esas marcas que sirven de señales que llaman a la producción de sentido y que configuran la necesidad de un lector activo que pueda actualizarlos y plasmar el objeto estético, según los postulados de Iser $^{22}$.

A propósito de la experiencia infantil de deseo, Schmidt-Cruz explica:

The desired women, as substitutes for the forbidden maternal figure, embody the male subject's fantasies directed at her. This can explain the male characters' tendency to idealize women, as well as their highly ambivalent attitude toward their female counterparts, simultaneously desiring and dreading them. While union with the mother or mother substitute remains their deepest longing, they fear her power to castrate, overwhelm, or reengulf them, at the same time that they fear punishment for their guilty desire. (81)

En el caso de "Voz en el teléfono", aunque el protagonista es niño, exhibe las actitudes que Schmidt-Cruz detecta en el comportamiento de los hombres en los cuentos de Cortázar y su reacción ante las mujeres: "The reactions of mastery, control, and distance

\footnotetext{
22 "Según Iser, los "espacios vacíos" (blanks) del texto regulan la actividad representativa del lector, quien se ve obligado a completar la información ausente y a tender un puente entre los segmentos textuales que aparecen inconexos. La indeterminación, en suma, se revela, no como obstáculo, sino como punto de partida imprescindible para la comunicación literaria.” (248) En Santiago Juan-Navarro. "79 ó 99 / modelos para desarmar: Claves para una lectura morelliana de "Continuidad de los parques" de Julio Cortázar" Hispanic Journal 13,2 (1992): 241-249.
} 
... are a type of defense mechanism against the experience of helplessness in face of their overpowering desire for the mother.” (81) Tal es la explicación psicoanalítica de la reacción de Fernando que Ocampo pone en juego para el lector. Al descubrir el "juego" de los adultos simplemente por su presencia en un lugar vedado, el niño se vuelve agente acusador de la conducta trasgresora que los adultos realizan a sabiendas mientras que no sea observada o llevada al espacio público.

En ese momento sonó el teléfono que estaba colocado junto a uno de los sillones; Chinche y Elvira, repartiéndoselo, lo atendieron; luego, tapando el teléfono con un almohadón, dijeron a mi madre:

-Es para vos, che.

Las otras se codearon y Rosca tomó el teléfono para oír la voz.

-Apuesto a que es el barbudo - dijo una de las señoras.

-Apuesto a que es el duende -dijo otra, mordiendo sus collares.

Entonces comenzó un diálogo telefónico en que todas intervinieron pasándose el teléfono por turno. (énfasis mío)

En este punto se pliega el relato pues el hecho que se narra a continuación dará cuenta del desenlace. Es en este momento que, sin entenderlo completamente, Fernando descubre la traición de su madre y toma los fósforos en un impulso que traerá consecuencias nefastas.

Olvidé que estaba escondido y me puse de pie para ver mejor el entusiasmo, con tintineo de pulseras y collares, de las señoras. Mi madre 
al verme cambió de voz y de rostro: como frente al espejo se alisó el pelo y se acomodó las medias; apagó con ahínco el cigarrillo en el cenicero, retorciéndolo dos o tres veces. Me tomó de la mano y yo, aprovechando su turbación, robé los fósforos largos y lujosos que estaban sobre la mesa ... Salimos del cuarto.

-Tenés que atender a tus invitados -dijo mi madre con severidad-. Yo atiendo a los míos. (énfasis mío)

Un rasgo típico de la narración ocampeana es que el punto de vista se concentra en imágenes particulares y detalles específicos que desfamiliarizan la escena: sin ocultar los detalles más sórdidos o comprometedores que acusan al narrador del crimen.

Me dejó en la sala desmantelada, sin alfombra, $\sin$ los objetos habituales de las vitrinas, sin los muebles más valiosos, con los caballitos de cartón vacíos, con las cornetas y flautines en el suelo, con los automovilitos todos con dueños que eran impostores para mí. (énfasis mío)

Este pasaje encierra la clave de la carencia y el móvil del crimen. Es un ejemplo de esa insistencia en detalles secundarios, que se lleva a cabo por efecto de acumulación, por la constante repetición y que ocultan a plena vista los pasajes claves para la reescritura del relato. El enfoque en los detalles del cuarto desmantelado en contraste con el lujo habitual, más las muletillas y las repeticiones: “fui yo... fui yo... fui yo...”, la mención del mueble chino, el mueble más valioso, la descripción de las figuras del mueble, la 
focalización en las llamas, en la llegada de los bomberos, las reacciones a los hechos antes que los hechos en sí-son claves de los espacios de indeterminación.

La voz narrativa infantil se convierte en una estrategia para generar la ambigüedad que parte del narrador poco fiable ya que el lector siempre alberga dudas sobre el grado de comprensión de los hechos por parte del narrador así como sobre su credibilidad. Es frecuente la descripción de hechos atroces a través de la mirada infantil (Suárez Hernán, 373)

No estamos ante lo innombrable, ni ante una negación, conductas típicamente asociadas a experiencias traumáticas y al manejo de la culpa. En cambio, sí hay un distanciamiento emocional y psicológico que permite ver los hechos desde afuera, casi con el desapego del psicópata. Puede decirse que se ve una total falta de empatía por las víctimas del incendio. El narrador presenta su caso, su confesión, su explicación pero no busca la absolución del interlocutor ni de nadie, tampoco la del lector implícito. Mediante la selección de detalles, la autora tampoco parece proponer un juicio de valor sobre el personaje ni los hechos narrados. De allí surge la pregunta: ¿cuál es, entonces, el propósito, el fin, si cabe, de la comunicación? Según Mancini, no hay espacio para una lectura irónica, simbólica o moralizante. (“Amo y esclavo” 86) Ese espacio en blanco se constituye para la producción de sentidos por parte del lector activo.

Esta característica de los cuentos de Ocampo que ilustra "Voz en el teléfono" muestra la concepción de la autora acerca de su labor narrativa: Ocampo escribe para que sus cuentos sean leídos y escritos. Esta aparente tautología requiere de precisiones, a saber: los espacios de indeterminación, son comparables a la página en blanco que se le 
presenta al lector para que escriba en ella, de modo que luego esa página se agregue a las que venían dadas. Con los materiales que el autor selecciona y pone en boca del narrador, el lector debe completar el sentido. Lo que sucede es que muchas veces, como en este caso, el caudal de elementos es un obstáculo que debe sortear. El lector debe ser capaz de leer el texto que está detrás del cúmulo de datos y repeticiones. Si el narrador admite su responsabilidad en los hechos (a diferencia de otros narradores confesionales como en el caso de “La oración”) es porque con ese gesto dirige hacia otro rumbo la mirada del lector sobre el acto cuya crueldad supera la del crimen: el abandono y aislamiento del menor y su falta de atención y de amor por parte de los adultos. Las peripecias del relato construyen un círculo cuyo centro y signo es la carencia.

Queda claro, sin duda, que el texto presenta suficientes claves para su interpretación en el marco de la teoría psicoanalítica, a partir de la tematización del complejo de Edipo. No reside allí la “novedad” de la obra en el marco del estudio de la obra cuentística ocampeana. Es decir, la novedad no se evidencia tanto en el fondo como en la forma. El texto se constituye como una opera aperta a la generación de sentidos, y, en términos barthesianos, como écriture. La tematización de este complejo está escrita por el narrador y el lector.

El lector es siempre co-partícipe, un lector activo, es cómplice, es espectador obligado a pesar de carecer de poder para intervenir en la escena. La potencia de las imágenes que caracterizan los cuentos de Ocampo hace que éstas trasciendan la página impresa y permanezcan en el lector: there are no innocent by-standers. 
Si el espejo es la escritura, la confesión es un acto de auto-conocimiento: “dentro de lo que se considera anormal, juega un papel preponderante toda subversión del orden preestablecido, especialmente en lo referente a los roles de autoridad” (MurilloChinchilla 68) Schmidt-Cruz reflexiona sobre el valor que encierra la narración como acto de escritura, de confesión: "The act of writing the stories has a restorative effectthey function as a working-off mechanism to dissolve the tension by changing the conditions. After all, doesn't the storyteller possess absolute control over his characters' fate?” (81) La voz narrativa encuentra en la confesión la forma de dar cuenta de los eventos traumáticos, tanto los que recuerda, de los cuales tiene conciencia, como de los que quedan ocultos.

Como bien lo ejemplifica Fernando, en los narradores niños no hay nostalgia, no hay idealización de la infancia. En cambio, su relato les permite revelar la dominación de los niños por los adultos y las estrategias a las que acuden para subvertir esa estructura. Como en otros cuentos donde se ven alianzas entre los oprimidos o marginados, la frecuente alianza entre niños y criados está presente en este relato. Fernando se acerca al cocinero:

¿Te parece que vivía como un rey? No creas. Siempre había líos entre los sirvientes. Se habían dividido en dos bandos: los partidarios de mi madre y los partidarios de Nicolás Simonetti. ¿Quién era? Nicolás Simonetti era el cocinero: yo lo quería con locura. Me amenazaba, en broma, con un enorme cuchillo lustroso .... Él contribuyó tanto como mi madre a 
despertar mi pasión por los fósforos, que encendía para que yo los apagara soplando. (166)

El mundo del niño se caracteriza de un mundo homogéneo, un continuo, fluidez entre la vigilia y el sueño, la realidad y lo onírico, lo animado e inanimado, es el estado oceánico, homogéneo del que habla Freud. El momento del descubrimiento, sin embargo, siempre llega. La separación de la madre y el nombre del padre lo alejan de ese lugar feliz, aprende las diferencias al encontrarse con el mundo de los adultos, caracterizado por el egoísmo, la hipocresía y la soledad.

En “Voz en el teléfono”, el narrador recuerda un suceso de su niñez a partir de una explicación de la razón por la cual no puede encender un cigarrillo ni le gustan las fiestas infantiles. Lo que tendría que ser una conversación deviene monólogo pues las intervenciones de su interlocutor son inexistentes o bien están mediadas por el narrador, que las interpola en su discurso. Esta ruptura de las convenciones echa por tierra las expectativas del lector creadas por el título del cuento. Al hablar de una "voz” en el teléfono, se esperaría un diálogo telefónico, una situación de comunicación entre un emisor y un receptor cuando menos. A medida que avanza el relato, queda claro que la palabra la tiene uno de los personajes solamente, el narrador y las intervenciones del receptor se incorporan al "monólogo" sólo en forma indirecta. Se ve que la elección de la palabra “voz” en el título del cuento en lugar de “voces” que resultaría más natural, no es arbitraria sino que anticipa la forma que adoptará la narración.

Tras una breve alusión a hechos del presente narrativo que ameritan una explicación, el relato adopta la forma del recuerdo o “flashback” de la niñez del 
protagonista-narrador (analepsis). Este recurso se asemeja a una regresión en el sentido clínico del término en el marco de la práctica psicoanalítica. Los hechos narrados pronto pasan de la mera anécdota a la confesión. Mediante un juego de ocultamiento y revelación selectiva que opera en el nivel de las convenciones genéricas, Ocampo construye el relato desde la perspectiva de un narrador testigo. “Quien escucha su mal oye” reza el proverbio. Sin embargo, no se trata aquí de una violación de la confianza sino de un acto de complicidad entre narrador y lector. "Según la teoría todoroviana, el relato fantástico prefiere el recurso al narrador protagonista, dado que la carga semántica del “yo” involucra a todas las personas.” (Murillo-Chinchilla, 68)

El cuento reconstruye, retrospectivamente, en primera persona, la infancia del personaje. A través de un proceso de desfamiliarización se revela la relación ambivalente de Fernando con su madre, su padre y el cocinero. Atracción maternal peligrosa, deseo maternal, venganza por celos ante el rival y ante el engaño y el abandono. En el triángulo Fernando - Madre - Barbudo - Duende, el de la voz en el teléfono, se descubre la fuente del tercer trauma de Fernando y la causa de la traición de la madre. La relación extramatrimonial de la madre con el hombre de la voz en el teléfono es el origen del displacer de Fernando por el uso del teléfono. Este trauma y su fuente no están explícitos como los de los fósforos y las fiestas infantiles. Sólo se ve en retrospectiva. En principio, el título parecía aludir al protagonista-narrador, cuyo nombre se conoce ya dentro del relato. Ésta es una pista falsa o bien una distracción de la autora para encubrir la fuente del problema (la conversación entre la madre y el Barbudo-Duende, supuesto amante de la madre). En el triángulo Fernando - Madre - Cocinero la rivalidad entre la madre y el 
cocinero termina con una discusión que causa su partida. Fernando pierde por culpa de la madre al cocinero que, en la mente del niño, ocupaba un lugar clave como sucedáneo de la figura paterna. De esa primera decepción, Fernando pasa a la segunda: el desenmascaramiento de la madre. La imagen que había construido de ella queda hecha pedazos, también como objeto de deseo queda anulado ante la presencia del hombre de la voz en el teléfono, por lo tanto, el paso siguiente es la anulación del dolor a través de la destrucción del objeto del deseo.

“The triangular structure is a reenactment of the Oedipal scene, an evocation of the boy rivalring his father for the mother .... Omnipresent betrayal motif ... Sexuality and eroticism are laced with violence.” (Schmidt-Cruz 85) El precio de la traición es la muerte. Ante la ausencia del padre, del Nombre, según Lacan, el hijo se constituye ángel vengador. "Incapaces de amar... solo conocen el deseo y la posesión. Buscan desesperadamente la reafirmación de su ego" (Antonio Planells "Represión sexual" 233 citado en Schmidt-Cruz) La imposibilidad de hacerlo lo llevará a eliminar los obstáculos que se le presenten. Para el protagonista de "Voz en el teléfono”, la obsesión con la madre es la fuente de su incomodidad con lo femenino. Esto lo impulsa a establecer una relación con el espacio femenino, desde una postura defensiva y complicada según se desprende del análisis de la retórica del discurso del personaje.

Existe un elemento paródico en "Voz en el teléfono”. Ocampo hace una parodia de los conceptos centrales del psicoanálisis, principalmente, del complejo de Edipo. Asimismo, parodia la técnica de análisis en una sesión. Termina haciendo con el 
personaje lo que detesta que le hagan a ella: “psicoanalizarla”. ${ }^{23}$ Entiendo que en esta operación se plantea la posibilidad del comic relief para el lector, aunque su efecto sea colateral y menor al que configura el relato.

\section{Compárese este narrador en primera persona con otros tantos que realizan una}

“confesión” explícita o indirecta: la narradora de “La propiedad”, la de “La oración” y el narrador de “La furia”. En las primeras, se puede ver un distanciamiento entre los hechos narrados, el punto de vista expreso y la percepción del narrador frente a la “realidad”, las verdaderas intenciones que el lector desenmascara a partir de las pistas que le da el autor implícito $^{24}$. En el segundo caso, “Voz en el teléfono”, el distanciamiento de los hechos

\footnotetext{
${ }^{23}$ Noemí Ulla recuerda en el prólogo a Invenciones a dos voces lo difícil que le resultó lograr la serie de entrevistas con Silvina Ocampo, quien "se negaba constantemente al asedio de las preguntas, a someterse al trabajo regular de una larga conversación”. Una vez iniciado el proyecto, Ulla cuenta que en cierta ocasión estuvo a punto de quedar inconcluso: "tras diversos avatares en que mi entrevistada quería abandonar los encuentros porque se sentía psiconalizada (S.O. -“Vos me estás psicoanalizando” me dijo una vez con cierto recelo. Y le contesté: “Podría ser. A lo mejor es así”), las charlas se cumplieron.” Esa objeción a ser psicoanalizada fue uno de los motivos por los cuales dejó de asistir al atelier del pintor Giorgio De Chirico, con quien estudió dibujo y pintura en París. Según la anécdota que recuerda Ocampo, en vez de hablar de pintura, De Chirico estaba más interesado en psicoanalizarla.
}

${ }^{24}$ En su comentario sobre estos cuentos, Murillo-Chinchilla explica que si bien en ocasiones Ocampo recurre al narrador omnisciente y "la voz narrativa tiene tintes marcadamente psicológicos ... en otros aunque narrados en primera persona, cuentan la historia de terceros.”

Según Murillo-Chinchilla,

Es desde esta perspectiva que la autora logra explotar mejor las posibilidades siniestras de sus motivos narrativos. Resulta escalofriante (pero fascinante) adentrarse en la sordidez ajena; el enfoque consigue convertir en virtud narrativa el interés morboso por la vida de los demás. ... comprender la fruición que experimenta el lector al entrar en conocimiento de las pequeñas miserias de otro.

Hasta este punto coincido en que el lector participa de la mecánica del fisgón de lo cual deriva un cierto placer. Sin embargo, difiero en las observaciones acerca del efecto de resguardo para el fisgón que supone la intervención del fantástico, es decir, de la desmamiliarización operada en el nivel del relato:

Se trata de la contemplación desde la comodidad, desde la fantasía, desde la posibilidad de evadirse para escapar de lo siniestro que resulta de la emergencia de lo reprimido. El contrato de lectura reposa, entonces, sobre la aceptación condicionada de lo perturbador; condicionada porque el lector se aferra inconscientemente al carácter ficcional de la puesta en escena.

Cabe mencionar que esta característica reviste especial importancia si se le observa a partir de los postulados todorovianos de la vacilación inherente al género, es claro que la construcción narrativa y la progresión de la lectura invitan al lector a asumir como cierta 
narrados de la percepción del narrador, si bien constituye una ironía de situación, obedece a una incongruencia en la reacción del protagonista-narrador motivada por una insuficiencia o una debilidad en su persona, que los lleva a admitir la culpa a pesar de no ser conscientes o no reconocer la magnitud de los hechos. El lector percibe esa incongruencia entre las acciones del narrador y la situación, pero no llega a condenarlas por advertir la falencia, el defecto. La "sinceridad” de su confesión opera en el lector la conmiseración por el narrador, un cierto grado de comprensión, si no aceptación, que el narrador no pide explícitamente pero que precisamente, por no hacerlo, le es concedida.

En "Voz en el teléfono”, Fernando busca simplemente explicar una fobia aparentemente trivial que podía ser objeto de burla por el lector o un espectador, quien, empero, al conocer las circunstancias que lo motivaron, otorga la conmiseración porque en el relato el narrador no sólo admite la culpa sino que revela, sin ser consciente de ello, mucho más de lo que esperaba. Para el interlocutor, esa revelación, de la cual el narrador no parece ser consciente, porque está codificada con el discurso del narrador-niño (el narrador "inocente"), es la que pone en contexto los hechos criminales del niño como producto de una situación insostenible generada en el seno del hogar, que, lejos de ser el espacio de amparo para el niño en desarrollo, se revela como el lugar de la soledad y el abandono.

la historia presentada, pero al mismo tiempo, su aceptación provoca la rebelión de la consciencia; el lector se recuerda a sí mismo que lo que está leyendo pertenece al mundo de la ficción; así lector oscila entre los opuestos. (Murillo-Chinchilla 68-69) No comparto la idea de que se configure en el fantástico ocampeano una vía de escape, una salida de emergencia para el lector. Me parece que Murillo-Chinchilla confunde las nociones de lector implícito que maneja Todorov en la discusión del género fantástico, con la del lector empírico. Es precisamente la característica opuesta, la ausencia de cualquier escapatoria, la complicidad del lector en el pacto de lectura, lo que emana de la narrativa ocampiana. 
A pesar de que la infancia está más que desmitificada en los cuentos de Ocampo como un espacio donde los niños son capaces de cometer las atrocidades más grandes, al igual que los adultos, este relato de la infancia infeliz y traumática del narrador de "Voz en el teléfono” parece granjearle un cierto grado de compasión por parte del lector, que ve en los hechos el atenuante de su crimen. Además, no implica esto la “absolución” del narrador pues está claro que está pagando por su crimen a su manera, llevando años después la carga de lo sucedido sobre sus hombros, hecho que le impide desarrollarse plenamente como persona y funcionar con un mínimo de adaptación social y aceptación en un medio social de adultos.

La fragmentación de la identidad en “Cornelia frente al espejo”

Cornelio Agripa, Arquímedes, Narciso

perros, barcos, amores que anegaste

en tu agua límpida como el Cefiso

conmigo revivían: los amaste

porque buscaron tu complicidad

en el reverso de tu claridad.

Del poema “Oblicuo espejo” (1953)

Publicado en 1988, el cuento “Cornelia frente al espejo” que da título al volumen que integra, constituye la última colección de cuentos que se publica en vida de la autora. El relato se inicia con un monólogo en primera persona "De todo el mundo me despido 
por carta...” Ya desde la primera oración, la presencia de un pronombre de segunda persona “salvo de vos” marca un interlocutor implícito. El pronombre en segunda persona facilita el cruce de la frontera del relato hacia la identificación de ese interlocutor implícito con el lector. Otras referencias directas al interlocutor, “qué quieres” o “te miro” al igual que el tenor del contenido de la enunciación denotan un tono de intimidad, cercanía y confianza en su trato con el locutor. A pesar de la ausencia de marcas textuales que lo definan como diálogo, el contenido y el estilo del pasaje exhiben marcas de oralidad. La narradora, que dice llamarse Cornelia, parece estar entablando un monólogo consigo misma por las digresiones en las que incurre o con alguien que está en presencia suya y que la escucha. Decíamos que se trata de alguien cercano por el tipo de revelaciones que hace. Ocampo logra caracterizar el tiempo y el lugar de la acción en espacio de unas pocas líneas y en forma indirecta, por alusión de la narradora.

El espejo es uno de las imágenes predilectas de Ocampo. Aparece en numerosos cuentos como elemento temático o estilístico. Por ejemplo, en “El castigo”, Ocampo comienza una enumeración de lo que le gustaba a la protagonista con "un espejo donde soñaba que era siempre distinta” (Grondona 176).

El poema “Los espejos” desarrolla los tópicos que se encuentran en “Cornelia frente al espejo” y establece una relación entre los textos análoga al planteamiento teórico y la puesta en práctica. Este rasgo de Ocampo es notable pues en diversas ocasiones aborda un tema desde la prosa o el verso, con distintos efectos estéticos. Ulla comentó con Ocampo este juego de dobles, esta imagen especular que se establece entre los textos. La característica común más sobresaliente en este caso es la coincidencia de la primera 
persona del singular en la enunciación y la narración tanto en el poema como en el cuento.

En el presente cuento, la focalización del personaje es interna. El nombre de la protagonista es una referencia a Enrique Cornelio Agripa de Nettesheim, quien practicaba la adivinación con un espejo. De occulta philosophia libris tres (1533). La alusión al personaje histórico plantea la indentificación de la protagonista, Cornelia, con un ser que adivina frente al espejo y lo que busca adivinar, intuir, es la imagen propia. De allí, el diálogo que entabla con el espejo tenga la forma de una confesión, de una indagación de la verdad.

La estructura del cuento es de una simplicidad engañosa. Consta de diferentes secciones sin marcas textuales que las identifiquen. Alternan los tiempos de la narración entre el presente narrativo y la evocación de momentos anteriores en el relato que se actualizan mediante el diálogo. Los cambios de fragmento no van precedidos de ningún tipo de introducción ni intervención de un narrador en tercera persona. Es muy difícil seguir el hilo de la acción si bien los hechos del argumento no son complejos pues el punto de vista es el de la narradora protagonista y la trama se articula por medio del diálogo. El lector no tiene más asidero que el discurso de la narradora protagonista y su intercambio con los personajes. Como en los ejemplos anteriores, se nota una constante: la preferencia por la enunciación en primera persona con la ventaja que ofrece.

Los personajes representan otro detalle de cuidado en el análisis. El texto deja lugar a la ambigüedad en cuanto a su número e identidad. Entre narradora, e interlocutores se encuentran Cornelia, el espejo, Cristina Ladivina, el ladrón-asesino, 
Daniel, Elena Schleider, Pablo, las clientas de la casa de sombreros. No hay una caracterización de cada uno por lo que no se puede decir que son personajes redondos sino meros esbozos. Algunos constituyen verdaderas dramatis personae por su relación de interlocutores de la protagonista: el espejo, Daniel, el ladrón-asesino, Cristina Ladivina. Otros, son interlocutores y protagonistas del relato dentro del relato: Elena Schleider, Pablo. En un tercer grupo o subcategoría se encuentran las clientas de la casa de sombreros, cuyos parlamentos sea actualizan en la voz de Cornelia, en una especie de caso de ventriloquia. En algunos casos, queda planteada la duda sobre su existencia en el mundo narrativo o si constituyen un producto de la imaginación del personaje. Los personajes como proyecciones del yo desde el punto de vista psicoanalítico.

Conviene recordar la definición del Diccionario de símbolos incluye un detalle de interés para el análisis de este cuento: “El espejo dice la verdad”. En este cuento se presenta el espejo como un dispositivo de encuadre, en su sentido figurado y literal. Como el espejo siempre dice la verdad, representa el verdadero yo y no un simple reflejo de la realidad. "Espejo es mágico ... Sirve entonces para suscitar apariciones, devolviendo las imágenes que aceptara en el pasado o para anular distancias reflejando lo que un día estuvo frente a él y ahora se halla en la lejanía.” Por eso entra en juego una posible interpretación sobre la identidad de los personajes: los personajes como apariciones del mundo del espejo. Seres que se reflejaron un día en él y salen cuando se contempla Cornelia, precisamente en el momento de transición que constituye la muerte. Cornelia les abre la puerta para entrar ella en el otro mundo. Si recordar es reconstruir la identidad, morir es la desintegración del yo. 
Como en otros relatos fantásticos que se han analizado, la irrupción de un elemento desestabilizador de orden fantástico como el hecho de que el espejo responda, no sólo inscribe el cuento en ese ámbito sino que posibilita la identificación de cada personaje como un reflejo-proyección de Cornelia: el espejo le devuelve distintas imágenes de sí misma en un juego de dobles en línea con el espejo, el espacio de articulación del doble por excelencia.

Es notable que en su devaneo previo a la muerte, Cornelia, la protagonista discurra sobre asuntos que no hacen en sí a la acción, desmarcando la trama de la acción dramática que hubiera podido sugerirse al principio. Hay referencias literarias como relatos clásicos: “Las mil y una noches” que, irónicamente, comprende el relato de cuentos para diferir una muerte anunciada o "Barbazul” que, abre las significaciones a la anticipación de la muerte. Por otro lado, las referencias a la mitología no pueden estar ausentes ya que constituyen una marca de estilo para la autora y un testimonio de sus lecturas preferidas. Asimismo, la alusión al retrato de Lady Talbott de Petrus Christus en la caracterización de Elena Schleider que representa un guiño autobiográfico a la labor plástica de Ocampo. Finalmente, la mención de “La muerte del cisne”, el ballet de Anna Pavlova como imagen de refuerzo del fin esperado por la protagonista. Todas las referencias a los distintos ámbitos del arte funcionan en un segundo nivel de significación como ejemplo de un tipo de reflejo, el espejo de la mímesis, donde la vida imita al arte y el arte imita a la vida.

A medida que avanza el relato y se acerca el desenlace esperado de la muerte, se verifica una confusión de voces en los diálogos. Se hace más difícil llevar el hilo de la 
conversación y atribuir a uno u otro personaje (voz) los enunciados. Se ve en ese detalle, la dramatización de la identidad fragmentada, por un lado, y la imposibilidad de controlar y reconciliar las partes conforme la conciencia se debilita. La ilusión de unidad y de verdad que inicialmente proyectaba el espejo, en su labor facilitadora de la liberación del yo, y su entrada en el orden simbólico, es contrarrestada por la proximidad de la muerte que libera al yo a partir de su anulación. El espejo permite al sujeto descubrir su propia identidad su auténtico ser: el no ser nada. Así, un sentimiento nihilista invade las páginas del relato actualizando su reflexión sobre la naturaleza de la identidad individual. Así, también se verifica la muerte y la anulación del espejo como agente que devuelve la imagen "real" del sujeto y le permite identificarse como tal, la etapa imprescindible en el desarrollo psicológico según Lacan. Ocampo, por lo tanto, contradice la noción y el símbolo consagrado del espejo.

De esta manera, el cuento abre un abanico de interpretaciones: del tema del doble (desdoblamiento), predilecto del cuento fantástico, al motivo especular, la etapa del espejo, exploración psicológica de la construcción de la identidad (una lectura y una labor más profundas). El salto es natural. Compárese el tema del doble en el cuento "El impostor” y las proyecciones del yo en "Cornelia frente al espejo”.

En el primer caso, las convenciones del género proponen una lectura en clave fantástica, el protagonista y antagonista son desdoblamientos del mismo personaje. La propuesta viene del encuadre que proporciona el tercer personaje Sagasta, quien "resuelve” el misterio, o bien, deja más preguntas sin respuesta. 
En el caso de "Cornelia frente al espejo", la estructura abierta del relato, la ausencia de marcas textuales que orienten la lectura dificulta en un principio el acceso al texto. El tema del doble desde una perspectiva psicológica no surge de la lectura sino $a$ posteriori. La personificación del espejo es uno de los desdoblamientos de la protagonista. Los personajes se configuran como proyecciones del yo sólo a partir de la imagen con la que cierra el cuento: los fragmentos del espejo en los cuales se busca Cornelia. Del mismo modo, la estructura del cuento exhibe la misma marca pues está compuesta de fragmentos sin ilación en los que el lector implícito busca producir el significado de la obra. Este cuento puede considerase a partir del trabajo del autor implícito como metáfora de la creación literaria, de la identidad de autor. A partir de su experimentación formal cada vez más acentuada, éste como otros cuentos de Ocampo presentan en su superficie las marcas de la realidad deformada que representan. Son un espejo que destaca los rasgos más degradados del ser humano. En este sentido, es imposible no remitirse a los espejos deformantes de Valle Inclán. El cuento, la obra de arte, se levanta como un espejo infiel que, sin embargo, a partir de la exageración, obliga al lector a reevaluar su realidad. El valor positivo que conlleva esta posición en el horizonte de expectativas del lector es la de dejar las posibilidades abiertas, para constituirse como un ejemplo del texto escribible en términos barthesianos que produce jouissance.

La experimentación y renovación formal que Ocampo exhibe en sus obras de madurez como ésta abre el juego de la creación a partir del símbolo del palimpsesto. La indeterminación del género narrativo, o, mejor dicho, el cruce de los límites genéricos se 
da por la superposición de estratos (o capas) de diversos géneros en un mismo cuento. El efecto acumulativo parece un mecanismo de defensa contra la dispersión de los significados ante la pérdida de fe en el poder de significación del lenguaje que se correlaciona con la fragmentación de la identidad en la confusión de voces. Así, no parece verificarse una evolución o cambio de estilo sino una transformación, una reformulación a partir de elementos que se combinan para crear algo nuevo: un estilo único y de marca propia que explota las convenciones de uno o varios géneros para crear otro propio.

Entre las obras inéditas que Ernesto Montequin sacó a la luz, se encuentra una versión de este cuento en formato de obra de teatro. Bajo el título “El espejo ardiente”, la obra constituye una variación del tema "en el sentido musical de la palabra" como explica Montequin (Clarín). Presenta ciertos elementos que garantizan su asociación inmediata con el cuento con la diferencia en la organización, foco y selección de hechos. La acción transcurre en la casa de sombreros de la cual Cornelia es una empleada. La descripción detallada de los sombreros remite al cuento. Las voces de las clientas que Cornelia imita a la perfección, en la obra de teatro reciben un tratamiento de primera mano: los parlamentos de cada una de ellas son el original que luego Cornelia parodiará. El foco cambia a uno de los episodios del cuento, la muerte del pirómano, presentado, podría decirse, desde la vereda de enfrente. En la obra de teatro es el principal tema de discusión de empleadas y clientes. Cornelia es prácticamente desplazada a un papel secundario. La lectura de ambas obras en diálogo permite acceder al argumento desde una perspectiva 
múltiple y da fe de la incansable labor de escritura y reescritura a la que Ocampo sometía sus temas recurrentes o predilectos.

Si bien es sabido que Ocampo "evita en su obra narrativa cualquier vínculo directo con el ambiente político de su época” (Aldarondo, nota 17), llama la atención en manera especial que en esta oportunidad incluya una referencia a la quema de iglesias que partidarios de Perón llevaron a cabo tras el golpe militar que lo derrocó. La llamada “Revolución Libertadora” de los años cincuenta. Otro pasaje que se intercala en el relato dentro del relato, deja una alusión a otro momento de la historia argentina: la de la llamada "Guerra Sucia” de los años setenta.

—¿Por qué no sigue?

—No sé. Me parece que hablo en vano.

— ¡Por favor! Me hace olvidar el mundo horrible en que vivimos, las torturas.

—¿Las torturas?

—Sí. Las torturas. Siga. (160)

Resulta interesante que el salto temporal no atente contra la cohesión del relato, pues el lector ya está preparado a partir de las exigencias mayores que representa la lectura en otros aspectos. La novedad formal subsana las irregularidades espacio-temporales en materia de fondo. 
Las imágenes especulares son recurrentes en la narrativa y en la poesía de Ocampo. Evidencia de la preferencia de la autora por este tema es el tratamiento que hace de él en diferentes obras, desde cuentos y poemas hasta dramas.

La irrupción en el texto de digresiones enciclopédicas apunta a una ruptura de la forma, un quiebre de los marcos textuales. Esto es evidente en la versión teatral de la historia, El espejo ardiente, en boca del personaje, resulta un parlamento superfluo. Recién desde el final se descubre su función dentro del relato: la de encubrir lo que “realmente está pasando” o lo que "realmente quiere tratar el autor”. En un quiebre de las convenciones del género, la unidad de tiempo, de asunto y de lugar, nos encontramos con una obra de teatro que raya en el absurdo. Por tratarse de un género caracterizado por la acción, en El espejo ardiente, la acción es casi nula. La trama podría resumirse en pocas palabras: En una casa de sombreros dos clientes se prueban sombreros y hacen pedidos mientras conversan de generalidades. A través de las pistas que se recogen en el transcurso de la escena, el espectador reconstruye las acciones "secundarias" desde el punto de vista de la trama, que resultan "primarias” desde el punto de vista temático: el asesinato de un intruso por parte de Cornelia en la tienda. La acción no es más que la “coartada” de la historia. A medida que aparecen elementos fuera de lugar, la dueña intenta darles una explicación lógica, normalizar la situación: una colilla de cigarrillo, una copa de licor, entre otros. En una primera lectura, el espectador participa de su sorpresa ante lo inusual de los hallazgos. Unido al acontecimiento que consterna a todos los presentes y que se conoce sólo indirectamente, a través de la mención del artículo del diario y del testimonio de un testigo que viene desde el exterior. 
Como nota de cierre, considero importante proponer otra visión del cuento: como alegoría de la lectura y de la obra cuentística de la autora. Esta lectura se ve enriquecida a la luz de las referencias a personajes y cuentos de su obra precedente. El momento de publicación es significativo: etapa madura, donde ya despuntan los indicios de la enfermedad. Desde este punto de vista, la identidad del personaje se refleja en la identidad de la autora, es esa lucha contra la desintegración del yo y búsqueda de sentidos en el balance de la vida, tanto física como literaria, entra en juego con una declaración del cuento “Anotaciones”: “Quisiera escribir un libro sobre nada” (CCII 365). La lectura a la luz de los demás cuentos del volumen, los que se publican póstumamente, y los precedentes remite a la noción del pliegue, la órbita en espiral hacia la expansión y dispersión. Las obras son cada vez más desestabilizantes desde el punto de vista del lector. No es un todo monolítico sino una construcción que se expande, se metamorfosea, que continúa siendo susceptible de generar sentidos mucho después de su génesis. Su plena vigencia no admite duda al respecto. Demasiado moderna para su tiempo, perdura y se afianza en la historia de la narrativa argentina y universal. Pocas obras logran esa trascendencia. El reconocimiento, el rescate llegó tardíamente pero no ha concluido.

Por lo expuesto, considero que Ocampo logra a través de su motivo predilecto, el espejo, una exploración de la identidad del personaje y, por extrapolación, del ser humano al igual que una indagación acerca de la identidad del autor frente a su obra. Si “La calle Sarandí” es la búsqueda del espejo a través de los fragmentos de la memoria, un espejo-mosaico-rompecabezas, "Voz en el teléfono” sería el atisbo del sujeto frente a un espejo empañado que, poco a poco, se va aclarando, aunque no en forma completa. 
Siguiendo el juego metafórico, “Cornelia frente al espejo” es el descubrimiento del espejo roto, es decir, el quiebre de cualquier ilusión de posible unidad, ni siquiera en la muerte: desilusión y disolución del yo. Los visos fantásticos de los cuentos desrealizan los hechos para facilitar la exploración de las implicaciones tanto para el sujeto como para el autor. Como Cortázar, Ocampo sugiere, crea el suspenso, pero no dice sino que deja al lector sacar sus conclusiones aunque los dados están cargados, el discurso directo de apariencia objetiva es puramente tendencioso. Siempre alerta para eludir cualquier reduccionismo o petrificación, Ocampo demuestra a lo largo de su producción una evolución de la exploración de la identidad del ser humano y de la exploración de la identidad del autor en relación con su obra desde los primeros relatos de Viaje olvidado de filiación fantástica más abierta hasta los de Cornelia frente al espejo, donde el fantástico, todavía presente, asume otros visos de estilización que renuevan las formas del relato. 


\section{CAPÍTULO 4 - Silvina Ocampo y la escritura femenina}

Entre las vertientes de la narrativa ocampeana es imposible soslayar la temática de género. Desechando toda etiqueta de “feminista”, Ocampo, empero, actualiza en sus obras una praxis de la escritura femenina con su particular acercamiento a los asuntos de identidad genérica, espacio social, relaciones de poder (dialéctica hegeliana del amo y el esclavo), construcción de la sexualidad y el cuerpo femenino. Del mismo modo en que desde niña, en vez de enfrentarse abiertamente a la autoridad de los grandes, se escondía y hacía lo que quería, como escritora desdeña la vida pública del intelectual pero trabaja con ahínco desde su "cuarto propio”, donde, con plena libertad, puede dar rienda suelta a su creatividad y a su expresión.

Es insoslayable el comentario de Ocampo al respecto que Ulla consigna en Encuentros con Silvina Ocampo y luego recoge en Invenciones a dos voces:

En cierta oportunidad pregunté a Silvina Ocampo sobre las diferencias que encontraba entre la literatura escrita por hombres y la literatura escrita por mujeres, y su respuesta fue: "A veces pienso que en la literatura escrita por mujeres pululan mis defectos y en la escrita por hombres, otros defectos menores, ya que no son los míos, pero prefiero no tomar en cuenta el sexo de lo que estoy leyendo. Cuando se trata de perros, confieso que averiguo el sexo del perro que se acerca, si estoy en la calle con mi perra, y si es del mismo sexo, trato de evitar el encuentro, porque las perras se odian a muerte y me duele la violencia de los que se odian, ya sean hombres o animales. También averiguo de qué sexo es el eucalipto o el cedrón y en 
qué se diferencian los machos y las hembras de esas especies si quiero cortar sus ramas.” (“Las mujeres tienen la palabra", Clarín, 12-5-77)

Como es posible apreciar, su juicio está lejos de provenir del feminismo, y prefiere darle lugar dentro de la escritura. (Encuentros 54)

La digresión en el comentario es fascinante y típica de la idiosincrasia de la autora.

Este rasgo, esa preocupación, “feminista” que se detecta en su obra no se trata de una postura adoptada en respuesta a los movimientos feministas europeos y anglosajones o producto de la corriente que está en boga sino que se trata de una inquietud que se evidencia desde sus primeras obras. Como veremos, esa presencia, esa senda, en la narrativa de Silvina Ocampo, sí evoluciona en crescendo, pero, reiteramos, es un rasgo que obedece a una búsqueda y a una práctica personal: dentro de lo opresivo que podía resultar el círculo social de la alta burguesía argentina, en particular en lo que respecta a los cánones de la moral y las buenas costumbres, Ocampo "hace su vida” al margen de ellas, por ejemplo, conviviendo en pareja con Bioy Casares mucho antes de formalizar la relación con el matrimonio ${ }^{25}$. Temas tabúes, mujeres autónomas, homoerotismo, por nombrar algunos, ya figuran en los cuentos del primer volumen publicado: hecho que sin lugar a dudas contribuyó al desconcierto y a la sorpresa con la que se recibió su obra, aun en los círculos letrados que se consideran liberales. Para la sociedad patriarcal, la mujer es un ser “misterioso” que inspira a la vez atracción y temor, por lo que hay que controlarlo. Es de esperar, por lo tanto, que una mujer que escribe y que lo hace no sólo

\footnotetext{
${ }^{25}$ Silvina Ocamo y Bioy Casares contrajeron matrimonio en 1940 en el Registro Civil del pueblo de Las Flores, el más cercano a la estancia de la familia Bioy, "Rincón Viejo”, donde se había retirado la pareja desde mediadios de los años treinta. Borges fue uno de los testigos.
} 
desde el ámbito de la poesía (que estereotípicamente se considera un género de mujeres) sino que se adentra en la narrativa (espacio masculino privilegiado), represente una amenaza mayor. La estrategia de Ocampo es quedarse en el margen, en borde, donde puede observar mejor y crear en libertad "ese mamarracho genial” en el margen de la página que señalaba Drucaroff.

Siguiendo el eje temporal del estudio, los tres cuentos seleccionados corresponden a las tres etapas de la producción ocampeana comúnmente periodizadas por la crítica: los inicios, consolidación y madurez ${ }^{26}$, lo cual permite observar la paralela evolución de la temática femenina, la ampliación del margen, la incursión cada vez más profunda en los dominios vedados. Por otro lado, la selección ejemplifica otro de los rasgos distintivos de la cuentística de Silvina Ocampo, me refiero a su preferencia por las protagonistas mujeres, (prácticamente el noventa por ciento de los relatos). Ya Ulla había observado "su preferencia por las tramas que envuelven la peripecia de figuras femeninas, configurando un discurso donde lo femenino parece imponerse, aun con la ambigüedad proverbial que es notoria en la retórica de esta escritora”. (énfasis mío 15) Este espacio conquistado para la temática femenina supone, como efecto indirecto y secundario, el acotamiento del territorio masculino. La salvedad que Ulla puntualiza acertadamente “aún con la ambigüedad proverbial que es notoria en la retórica de esta escritora” no desmerece la contribución de Ocampo pero constituye una advertencia para el lector en cuanto a sus expectativas. Klingenberg advierte también: "Ferninist readers may wish for a healthier vision of women and their work, yet Ocampo's fiction is not in the business of health”. (“A Portrait” 63) En un ámbito signado por la rigidez, la propuesta ocampeana

\footnotetext{
${ }^{26}$ Ver el estudio de Graciela Tomassini, El espejo de Cornelia, citado anteriormente.
} 
no es agitar la bandera revolucionaria y alzarse en armas en pos de una utopía, pero su quehacer literario crea, silenciosa, subrepticia y sistemáticamente, espacios textuales donde las mujeres reclaman, descubren y adquieren visibilidad, agencialidad, “voz y voto”.

Como es evidente, la selección de los textos también gira en torno a una imagen común: el vestido. No es mera casualidad encontrar el vestido en distintas etapas de la narrativa de Silvina Ocampo como elemento productor de sentidos. Tampoco se trata de cualquier tipo de vestido, sino de un vestido de terciopelo, otro elemento que aparece muy asiduamente en los cuentos de tal manera que genera diversas expectativas. Viene cargado de una connotación más o menos estable como objeto de lujo y elegancia, objeto “aspiracional”.

Mostrar vs. ocultar y ser vs. parecer en "El vestido verde aceituna”

“Verde que te quiero verde” - Federico García Lorca

El cuento "El vestido verde aceituna” es uno de los primeros, pero no por ello menos logrados ejemplos del narrador ingenuo, que tanto abunda en la cuentística de Ocampo aunque no haya sido muy estudiado por la crítica. Hace parte del volumen Viaje olvidado, publicado en $1937^{27}$. En este caso, se trata de una institutriz inglesa, Miss Hilton, cuyo punto de vista asume la voz narrativa en estilo indirecto. En cuanto al aspecto de la trama, la acción es mínima: asistimos a la reconstrucción de los hechos que preceden al despido de la institutriz a raíz de un comportamiento tachado de inmoral por

\footnotetext{
${ }^{27}$ A pesar de la poca atención de la crítica, parece ser uno de los predilectos de la autora, ya que lo eligió entre tantos para integrar la antología Páginas de Silvina Ocampo seleccionadas por la autora publicada en 1984.
} 
parte de la familia que la emplea ${ }^{28}$. La focalización desde el personaje de Miss Hilton dificulta la reconstrucción de la trama para el lector, que debe armar el rompecabezas de la acción narrativa a partir de las piezas que surgen de la evocación-enunciación de Miss Hilton. Parte de la dificultad radica en el hecho de que la voz narrativa salta del presente narrativo a una retrospección en la que intercala cuadros descriptivos de la vida de Miss Hilton para construir el retrato del personaje.

La estructura de la narración permite la convivencia de dos puntos de vista, dos historias contrapuestas: lo que sucede en ese mundo ficticio y lo que Miss Hilton cree que sucede. La voz narrativa ofrece las impresiones del personaje y los hechos a cargo del narrador en tercera persona, pero focalizado en la protagonista. Esta técnica es una de las claves que construyen la ambigüedad de relato pues dejan la puerta abierta a una lectura irónica. Miss Hilton hace una cosa pero piensa otra; actúa de una manera pero desea hacerlo de otra.

La ambivalencia en el relato se instala desde las primeras líneas a partir de la descripción del personaje. “Las vidrieras venían a su encuentro. Había salido nada más que para hacer compras esa mañana.” (El énfasis es mío CCI 16) La voz narrativa modaliza la enunciación:

\footnotetext{
${ }^{28}$ El relato comienza in media res con Miss Hilton caminando por la calle, mirando vidrieras, luego de haber sido despedida y llega a la mercería donde, al momento de pagar, ve la nota de despido (presente de la narración). El relato se remonta, primero en los fragmentos descriptivos, al pasado remoto de la juventud de Miss Hilton, y luego a un pasado más cercano al presente narrativo, es decir los días previos al despido a partir del momento en que empieza a usar el peinado que le hizo su discípula y comienza a posar para el pintor. Llega al día anterior (supuestamente) al despido cuando lleva a la discípula al taller del artista donde ve los cuadros de desnudos.
} 
Miss Hilton se sonrojaba fácilmente, tenía una piel transparente de papel manteca, como los paquetes en los cuales se ve todo lo que viene envuelto; pero dentro de esas transparencias había capas delgadísimas de misterio, detrás de las ramificaciones de venas que crecían como un arbolito sobre su frente. (16)

Esa antítesis entre lo apariencia y realidad, entre ser y parecer que se plantea al inicio constituye un recurso sutil que dirigirá la lectura en el resto del relato. De entrada llama la atención el hecho de que la protagonista se presente como receptora de una acción (“venían a su encuentro”) por parte de un objeto inanimado ("las vidrieras”). Con una económica pincelada impresionista, la autora connota la pasividad de la protagonista y el estado de absorción en se encuentra. El primer dato que el lector recibe de ella es extraño pero en retrospectiva cobrará un nuevo énfasis: a la protagonista las cosas le suceden y ella no se da cuenta de lo que pasa. Se anticipa el interrogante: ¿no se da cuenta o no quiere darse cuenta?

El narrador, si bien adopta la tercera persona omnisciente, que de por sí presupone una mirada abarcadora, presenta los hechos con un cierto grado de objetividad, las dos caras de la moneda. Con ese "Había salido nada más que para hacer compras esa mañana” (énfasis mío 16) y gracias a la identidad de las formas verbales entre primera y tercera persona del singular, se produce un deslizamiento, una oscilación, entre la visión del personaje y la del narrador que, al coincidir, permiten que se pueda atribuir la frase al personaje con lo cual problematizan la acción y la enunciación. El lector de Ocampo ya está prevenido acerca de las estrategias desestabilizadoras, que pueden esconderse en los 
rincones más insospechados. Por eso, sabe que una simple frase puede esconder algo detrás. En este caso, la lectura llana con la enunciación atribuida al narrador no provoca ninguna inquietud, pero una lectura del enunciado como actualización del monólogo interior del personaje lo vuelve suspicaz: encuentra allí una señal de advertencia sobre la protagonista que "se está atajando". Inmediatamente el lector se pone en guardia y, gracias a la pista de la autora, tomará con pinzas la descripción de Miss Hilton pues la presunción de inocencia de alguien que se sonroja fácilmente y tiene la piel transparente como papel manteca (imagen que pone en juego la atribución de transparencia a su conducta también) queda socavada por el "pero" que la acompaña y muestra la otra cara “capas delgadísimas de misterio” que, al ser comparadas con un arbolito que crece, hace alusión a una cualidad arraigada de su personalidad. De aparente simplicidad, el recorte de los hechos y de las impresiones descriptivas, junto a la selección de los adjetivos, siguen una operación análoga al proceso de pensamiento del personaje, lo cual agrega un nivel de complejidad estructural acorde con la ambivalencia que la autora busca construir. A través de la descripción antitética:

No tenía ninguna edad y uno creía sorprender en ella un gesto de infancia, justo en el momento en que se acentuaban las arrugas más profundas de la cara y la blancura de las trenzas. Otras veces uno creía sorprender en ella una lisura de muchacha joven y un pelo muy rubio, justo en el momento en que se acentuaban los gestos intermitentes de la vejez (16)

el lector confirma las contradicciones que puede presentar el personaje y lo difícil que puede resultar el definirla: el ser o no ser, el ser y aparentar. La descripción antitética 
conduce a la paradoja: la identidad escindida de Miss Hilton, la doble cara, la dualidad del personaje, la intemporalidad de su estado. Asimismo, puede entenderse como la autopercepción del personaje, es decir, una radiografía de su estado mental: una mujer de edad madura que no quiere aceptar el paso del tiempo y lo inexorable de la vejez. Así como la protagonista de "La calle Sarandí” vive en sus recuerdos de infancia pero la mirada del lector la descubre ya anciana (aunque ella misma no lo comprenda ni se perciba como tal), Miss Hilton siendo anciana elije verse joven y pretende actuar como tal aunque resulte incongruente con sus circunstancias, como se verá.

La abstracción de Miss Hilton se explica en parte por el fragmento que sigue, el cual aporta una nota de exotismo y continúa ilustrando las capas de misterio a las que se aludió en el principio. Miss Hilton es un ser que está en el presente pero vive en el pasado. El paréntesis narrativo que se abre remite a los párrafos descriptivos del cuento tradicional, pero rompe cualquier matiz realista por el contenido exótico y la enunciación que hace hincapié en el tópico de la fantasía a partir del motivo del viaje. Sin embargo, con una clara voluntad antitética, el arranque de la analepsis está revestido de imágenes pedestres y alusiones vulgares que acometen los sentidos: había viajado por todo el mundo “en un barco de carga, envuelta en marineros y humo negro” (énfasis mío 16). Este detalle que puede perderse de vista como una ocurrente y original expresión idiomática (“envuelta” en lugar de “rodeada”) agrega una connotación negativa que, combinada a la ambivalencia de las imágenes que hasta el momento se han utilizado para delinear al personaje (antes descripto como transparente), sesga la mirada del lector. La sustitución del término “envuelta” en vez de la colocación normal (“rodeada”) atrae la 
alusión a "involucrada” o "enredada” con una connotación de promiscuidad. Esta línea de pensamiento se refuerza luego con otros ejemplos, otros datos seleccionados bajo el sesgo de la visión de la conducta de Miss Hilton en su juventud. Además de la nota de exotismo, los viajes por América, Oriente, Europa, humanizan a Miss Hilton a partir del detenimiento del lente en las emociones y sensaciones que aportan una nota de humanidad: es un ser activo, no convencional que tiene sueños ("Soñaba siempre volver a Ceilán”), que es capaz de despertar pasiones desbordadas ("volvía a viajar por la China, donde un chino amenazó matarla si no se casaba con él” (16)), que goza del peligro (“había conocido a un indio que vivía en un jardín rodeado de serpientes” (16)), que siente placer y que se abandona al goce de los sentidos (“Miss Hilton se bañaba con un traje de baño largo y grande como un globo a la luz de la luna, en un mar tibio donde uno buscaba el agua indefinidamente, sin encontrarla, porque era de la misma temperatura que el aire” (16); “Le gustaban más que los canales las calles angostas, de cementerio, de Venecia, donde sus piernas corrían y no se dormían como en las góndolas.” (17)), que experimenta emociones fuertes ("Volvía a viajar por España, donde se desmayaba en las corridas de toros” (16)) y ansia de conocimiento ("había visitado todos los museos” (17)).

Ante todo, sin embargo, es un ser que vive de recuerdos: “Toda su vida estaba encerrada en aquel baúl, toda su vida estaba consagrada a juntar modestas curiosidades a lo largo de sus viajes, para después, en un gesto de intimidad suprema que la acercaba súbitamente a los seres, abrir el baúl y mostrar uno por uno sus recuerdos” (16). El acto de abrir el baúl está subrayado como "un gesto de intimidad suprema que la acercaba súbitamente a los seres” (16) es decir, el ser absorto establece un lazo de comunicación 
con otros a partir del recuerdo, de las vivencias pasadas. El mostrar los recuerdos es mostrarse como ser humanizado, es un intento de comunicación aunque no llegue a concretarse o a ser correspondido. Sin embargo, cualquier amago de empatía que quiera despuntar en el lector queda neutralizado por la cualificación caricaturesca de ciertos elementos: los recuerdos que tanto atesora Miss Hilton son cachivaches comunes (piedras, pulseras, chales, serpientes embalsamadas, pájaros apolillados, etc.) que como ella han sufrido los embates del tiempo y que sólo tienen valor por su contenido afectivo y evocativo, pues la transportan de la casa de pensión al pasado remoto y exótico.

Resulta interesante que entre el elenco ecléctico de objetos y recuerdos, se mencionen prendas de vestir y accesorios: pulseras, chales, sombrero, traje de baño. Sin embargo, parece haber una seria omisión: el lector esperaría encontrar entre las prendas del recuerdo la prenda que le da título al cuento, es decir, el vestido verde aceituna. Su ausencia en este primer pasaje sobre el pasado no hace más que resaltar su importancia y alimentar la expectativa de su aparición. Sí cobra un papel relevante una prenda emblemática de lo exótico que se describe en detalle: un sombrero adquirido por Miss Hilton. "Se había comprado un sombrero ancho de paja con un pavo real pintado encima, que llovía alas en ondas sobre su cara pensativa.” (16) Lejos de ser simplemente una prenda de vestir, el sombrero cobra vida imbuido por las emociones que experimenta su portadora debajo de las alas de pavo real del sombrero “que temblaba anunciándole de antemano, como un termómetro, su desmayo” (16) o "la llevaba a regiones infinitas del sol, cerca de los alrededores de Bombay” (17) por contraste con el presente desagradable donde está, en el estudio del pintor "brumoso de humo”, (17) detalle que remite al barco 
de carga en el que había navegado "envuelta en marineros y humo negro”. (16) Por asociación, estaría ahora “envuelta en pintores” que, como se menciona unas líneas arriba "la habían mirado con insistencia": (17) dos ideas que se combinan para anticipar y descubrir la conducta impropia de Miss Hilton en el presente de su vejez y en el ambiente “civilizado” y cercano (que simboliza el deber, las restricciones de la interacción social y la norma) por contraste con el ambiente "exótico" y remoto (que simboliza la libertad).

La concatenación de ideas entre el ser y parecer, entre lo que Miss Hilton es y lo que aparenta ser, entre lo que admite ser y lo que es, entre lo que debe y no debe hacer, continúa desde el párrafo precedente cuando vuelve a la descripción del peinado de Miss Hilton. Éste fue hecho por "las manos de catorce años” de su "última discípula que tenía el capricho de los peinados” (17) y se revela, primero, inapropiado para una señora de su edad y, segundo, desprolijo y ridículo. Sin embargo, la disociación de Miss Hilton entre lo que es y lo que ella percibe, entre lo que muestra y lo que oculta, continúa y así lo puntualiza el narrador enfocándose primero en la perspectiva de Miss Hilton y en la percepción “real” para los terceros: “y desde ese día había adoptado ese peinado de trenzas que le hacía, vista de adelante y con sus propios ojos, una cabeza griega; pero, vista de espalda y con los ojos de los demás, un barullo de pelos sueltos que llovían sobre la nuca arrugada”. (énfasis mío 17)

De tres maneras similares, por repetición, se sugiere la idea de que Miss Hilton es consciente de su falta de propiedad aunque las construcciones gramaticales pasivas deslindan su responsabilidad que queda limitada sólo a la permisividad: 1) la insistencia es de su discípula que, "le había rogado que se dejase peinar un día que, convaleciente de 
un resfrío, no la dejaban salir a caminar” (17) (antes en la misma oración se incluye la palabra “capricho” en relación con la alumna) dos hechos inconexos por cualquier relación de causa-efecto; 2) su acción se limita a permitir: "Miss Hilton había accedido"; pero el motivo aducido "porque no había nadie en la casa” (énfasis mío 17) la implica como cómplice de una travesura, una transgresión a la vez que confirma la existencia de reglas de conducta que se perciben como apropiadas: se revela el doble estándar de Miss Hilton, quien actúa de una manera ante la sociedad y de otra muy distinta cuando nadie la ve; y 3) en el siguiente enunciado se repite la imagen de Miss Hilton como receptora de la acción, pero con la variante introducida por la sinécdoque que centra la atención en la agencia de las manos como si tuvieran voluntad propia y deslindaran cierto grado de responsabilidad de la discípula: “se había dejado peinar por las manos de catorce años de su discípula” (17).

El peinado de trenzas que Miss Hilton se dejó hacer introduce un cambio en la narración de los hechos. Se convierte en un eje sobre el cual giran los acontecimientos previos y los que se desencadenarán “desde ese día”. (17) La idea de un antes y un después en el presente de Miss Hilton nuevamente se refuerza por medio de la repetición del sintagma temporal: "Y desde ese día había adoptado ese peinado de trenzas... Desde aquel día, varios pintores la habían mirado con insistencia...”. (énfasis mío 17) Además del sintagma temporal, nótese el empleo de una construcción en voz activa: Miss Hilton “había adoptado ese peinado de trenzas” (énfasis mío 17) por primera vez en el relato de los acontecimientos del presente narrativo Miss Hilton aparece como agente y no mera receptora de una acción: actitud que se había circunscripto al relato de sus experiencias 
de juventud, in illo tempore, su vida de aventuras y viajes a lugares exóticos y remotos. A partir de “ese día”, (17) la actitud de Miss Hilton cambia: deja de vivir de recuerdos para actualizarlos. Por primera vez en mucho tiempo, desde aquel día se muestra, se descubre, reaparece, a partir de la mirada insistente de “varios pintores”. (17) Aunque no está explicitado en el texto, el hecho de que Miss Hilton llame la atención de los hombres aparece en un enunciado yuxtapuesto al enunciado sobre el peinado con lo cual parece sugerirse una relación de causa y efecto. Sin embargo, bien cabe la posibilidad de interpretar la relación como una “darse cuenta” por parte de Miss Hilton una vez que actúa en transgresión de la norma. La "travesura”, la contravención de las normas de lo que se espera de una mujer en determinada posición social y de determinada edad, es un despertar: abre los ojos, se libera, y así puede percibir la mirada del otro. La vena caricaturesca y burlona que se deja entrever en todas las descripciones y caracterizaciones de Miss Hilton y su conducta no eximen de su influjo a esta lectura de este episodio como experiencia liberadora. El humor de la autora está en dejar dos posibilidades de lectura abiertas y dar paso a la ambigüedad, una de sus estrategias favoritas. Así, esa "mirada insistente” (17) de los otros, la mirada masculina que libera la juventud dormida de Miss Hilton puede no ser tal y no tener otro motivo que el hecho de que luzca ridícula con ese “barullo de pelos”. (17) Es decir, que Miss Hilton llame la atención por su peinado puede obedecer a un motivo totalmente circunstancial y contrario a lo que ella percibe (que la miran por su cabeza griega) y que constituye su revalorización. Sin embargo, esas oscilaciones del texto, esos vaivenes, esos pliegues que el lector debe seguir no tienen fin pues acto seguido la mención de Miss Edith Cavell y la propuesta de que pose vuelven a sustanciar la interpretación de la nueva "visibilidad” que adquiere Miss Hilton. 
Nuevamente, lo que parece ser pista de un repliegue de la interpretación queda matizado por la incongruencia (o no) de la imagen que connota la mención de Miss Edith Cavell. A partir de este dato, la mirada insistente de los pintores se debería al “extraordinario parecido con Miss Edith Cavell” (17) y no a la ridiculez de su apariencia. Nótese que la mirada masculina no es la de cualquier hombre sino la de "varios pintores", (17) detalle que jocosamente pretende conectar con la alusión al arte de la frase previa "cabeza griega” (17) y al criterio no de uno sino de varios artistas. Aparentemente, la visibilidad de Miss Hilton es configurada por una mirada calificada, la mirada de un artista que busca plasmar lo extraordinario de su persona, no la de un hombre burdo que se burla de su apariencia ridícula. De nuevo, la ambigüedad de la frase que se instala por el uso de la palabra "pintores" puede hacer alusión al obrero que pinta, no necesariamente al "artista plástico”.

La comparación con la célebre enfermera británica, heroína y mártir de la Primera Guerra Mundial al morir fusilada por los alemanes por asistir a los soldados aliados a huir del territorio belga ocupado, puede resultar ambivalente según la lectura que se escoja: un elemento comparativo y paródico que, por el hilo que lleva la narración, puede configurar la burla del autor hacia su personaje, o bien un refuerzo de la visión sesgada y poco fidedigna que Miss Hilton tiene de sí misma. Sin la posibilidad de constatar si el parecido físico amerita la comparación, el lector debe elegir la opción más aproximada. Cabe la posibilidad de que la opinión del pintor sea ésa pues los datos históricos y el material fotográfico sobre Edith Cavell la describen como una mujer de madura, que murió a los cincuenta años de edad. Fuera del parecido físico, el valor demostrado por el personaje 
histórico resulta paródico en comparación con Miss Hilton cuyo mérito es haber recorrido el mundo en sus años mozos en circunstancias censurables para los cánones de la época. ${ }^{29}$ El hecho de que se haya desempeñado como dama de compañía de una argentina en Venecia sólo da cuenta de uno de los lugares que se mencionan de su recorrido. Es de suponer que los avatares del periplo obligaran a la joven intrépida a buscar un paso intermedio como personal de servicio por necesidad y de allí diera el salto a la profesión de institutriz, ocupación que gozaba de gran demanda entre las familias de la pequeña y alta burguesía argentina de principio de siglo XX (otro conocimiento extra-textual que ayuda a trazar posibles coordenadas temporales para el relato).

La comparación con Miss Edith Cavell en todo caso sirve para adelantar la acción narrativa: parece haber resultado muy halagadora para Miss Hilton pues, sin más preámbulos, el enunciado siguiente da por hecho la aceptación de la propuesta. “Los días que iba a posarle al pintor, Miss Hilton se vestía con un traje de terciopelo verde aceituna, que era espeso como el tapizado de un reclinatorio antiguo.” (17) La narración se reanuda con la descripción de la nueva rutina de Miss Hilton y la entrada en escena, finalmente, de la prenda que le da título a la obra. Se lo presenta como un “traje” y se agrega el dato sobre el tipo de paño “de terciopelo”. La elegancia que evocan esas imágenes queda matizada por la comparación de guiño burlesco que le sigue: “espeso como el tapizado de un reclinatorio antiguo". (17) El traje que cubre el cuerpo de Miss Hilton se compara con un objeto y, encima, con algo antiguo, lo cual pone de relieve la

\footnotetext{
${ }^{29}$ El cuento no ofrece pistas para una posible datación, un detalle que en realidad no hace a la historia. Sin embargo, por la referencia a Miss Edith Cavell (1865-1915) podría ubicarse en la Argentina de principios de siglo XX. La ejecución de Cavell junto con la invasión de Bélgica y el hundimiento del "Lusitania" fue ampliamente divulgada en los Estados Unidos y Gran Bretaña como parte de la propaganda anti-alemana.
} 
madurez de Miss Hilton y su cosificación por contigüidad de los signos. Asimismo, el reclinatorio, como objeto de culto religioso, desestabiliza la imagen que el narrador viene pintando de Miss Hitlton por ser lo opuesto de lo que sus vivencias revelan. Por otro lado, el vestido espeso se presenta como el término de una antítesis al ser combinado con el extravagante sombrero de paja que, como se observó, traslada a la portadora a sus días de aventuras de juventud. La decisión de Miss Hilton de combinar elementos tan dispares en su vestimenta evidencia el grado de autodeterminación que va adquiriendo al haber sido facultada para experimentar una segunda "primavera” tras la "imposición de manos” que le hiciera su joven discípula, en una especie de ritual simbólico que le infunde un segundo aire. Así, se lanza a la “aventura” de posar para un retrato, de entrar en el mundo del arte y elevarse por encima de lo banal y rutinario de su existencia como empleada.

El juego de percepciones que marca la acción de la protagonista, entre ingenua o sofisticada vuelve a aparecer en un enunciado descriptivo sobre el estudio del pintor que resulta muy revelador: "En las paredes colgaban cuadros de mujeres desnudas, pero a ella le gustaban los paisajes con puestas de sol, y una tarde llevó a su discípula para mostrarle un cuadro donde se veía un rebaño de ovejas debajo de un árbol dorado en el atardecer”. (énfasis mío 17) La misma estructura del enunciado precedente: “El estudio del pintor era brumoso de humo, pero el sombrero de paja de Miss Hilton la llevaba a regiones infinitas del sol, cerca de los alrededores de Bombay”. (énfasis mío 17) El movimiento oscilante entre la descripción de la realidad que resulta negativa o censurable y la objeción que parece interponer la percepción de Miss Hilton evidencian el conflicto interno de la protagonista. Cada ejemplo solidifica la posición de que Miss Hilton 
ingenua no es, sino que no quiere ver, elige no ver, y, es más, niega lo censurable o inapropiado de una situación que, de no mediar la norma externa que la condena, no habría impedimento para su goce. La sensualidad de las experiencias de juventud, la posibilidad de recuperarlas en la "segunda primavera”, el segundo aire de liberación que supone el actuar en vez de dejar que otros manden sobre ella es expresión de sus más íntimos anhelos, motivados por el principio del placer, en lo más profundo de su ser. Sin embargo, esos impulsos primordiales son reprimidos por el principio de la realidad, la internalización de la normativa social. La disparidad de ambos impulsos que experimenta el personaje da cuenta de la alteración de su percepción producto de la negación: le es imposible admitir "en voz alta” sus más oscuros deseos pues no es lo apropiado según la norma y la lucha interna altera sus mecanismos de percepción.

El efecto acumulativo de imágenes y estructuras similares en un espacio tan reducido no hace sino reforzar el juego de percepciones que estalla en el clímax de la narración:

Miss Hilton buscaba desesperadamente el paisaje, mientras estaban las dos solas esperando al pintor. No había ningún paisaje: todos los cuadros se habían convertido en mujeres desnudas, y el hermoso peinado con trenzas lo tenía una mujer desnuda en un cuadro recién hecho sobre un caballete. Delante de su discípula, Miss Hilton posó ese día más tiesa que nunca, contra la ventana, envuelta en su vestido de terciopelo. (énfasis mío 17)

La presencia de la alumna, su introducción en el espacio de la "aventura”, espacio que hasta entonces era exclusivo de Miss Hilton, introduce la noción de impropiedad en el 
plano de la conciencia de la institutriz: frente a ella, frente a un tercero que tiene la facultad de atestiguar la realidad objetiva, ya no puede seguir con los ojos vendados y hacer de cuenta que no pasa nada. La presencia de un tercero le impide seguir con el juego y su goce secreto pues la obliga a juzgar su conducta frente a la norma. La percepción de la disparidad entre el deber ser y lo que es da cuenta de su desesperación. Nuevamente ante el asomo de la culpa, su reacción es deslindar responsabilidad. La enunciación deja la voz activa para volver a la pasiva en lo que podemos llamar agencialidad tercerizada: los cuadros de paisajes "se habían convertido” en desnudos; “el hermoso peinado lo tenía una mujer desnuda”. (17) Ante la imposibilidad de admitir lo que hizo y al haber sido sorprendida in fraganti, Miss Hilton cae en la desesperación y se paraliza: “...posó ese día más tiesa que nunca... envuelta en su vestido de terciopelo.” (17) La reacción, sin embargo, resulta cómica pues Miss Hilton actúa fuera de toda lógica: aunque la pintura recién hecha es un desnudo cuyo peinado la identifica, Miss Hilton decide posar de todas maneras pero "más tiesa que nunca”, "envuelta” y “contra la ventana”. (17) Estas imágenes al ir antecedidas del deíctico “ese día” y el circunstancial de lugar “delante de su discípula” se presentan en oposición realidad-deber ser. (17) La voz narrativa pone de manifiesto el contraste: la oscuridad del estudio brumoso de humo se contrapone a la luz de la ventana; el cuerpo desnudo del cuadro que se muestra, al cuerpo vestido (“envuelto”) que se cubre debidamente; "los días que iba a posarle al pintor” sola, libre, en movimiento (como cuando se bañaba en Ceilán, se desmayaba en España o corría en Venecia) y “ese día... delante de su discípula” sujeta a la mirada de la norma "más tiesa que nunca” ${ }^{30}(17)$

\footnotetext{
${ }^{30}$ Cabe preguntarse si la conducta de Miss Hilton no esconde un rasgo más perverso y no confesado con
} 
La “pose” de Miss Hilton, su intento de guardar las formas, salvar la situación, resultará infructuoso. Llama la atención, empero, que siguiendo con su percepción distorsionada (¿realmente cree que puede hacer de cuenta que no ha pasado nada? ¿o no considera haber cometido una falta?), Miss Hilton intente retomar la rutina diaria: “A la mañana siguiente... fue a la casa de su discípula”. (17) Algo anda mal: "no había nadie” (17) una frase que remite al día de la "travesura” del peinado pero que cobra un significado distinto pues esta vez Miss Hilton queda sola, aislada de todo contacto humano. Sólo "la esperaba un sobre con el dinero de medio mes, que le debían, con una tarjetita que decía en grandes letras de indignación, escritas por la dueña de casa: 'No queremos maestras que tengan tan poco pudor’.” (énfasis mío 17) Nuevamente el recurso de prosopopeya ("la esperaba un sobre”) la vuelve objeto y no sujeto de la acción, por un lado, y circunscribe el sentimiento de indignación de la familia a las “grandes letras” de la nota de despido, por el otro. (17)

La voz narrativa se vuelve ambigua al describir la reacción de Miss Hilton: “no entendió bien el sentido de la frase; la palabra pudor [sic] le nadaba en su cabeza vestida de terciopelo verde aceituna.” (17) El enunciado abre la posibilidad de dos lecturas tal

respecto a su decisión de llevar a la discípula al estudio del pintor: una especie de impulso de exhibición, basada en la dinámica de mostrar-ocultar, (práctica que ejercía con sus recuerdos de viaje "en un gesto de intimidad suprema que la acercaba súbitamente a los seres, abrir el baúl y mostrar" (16)) que hace las veces de una experiencia de iniciación.

En las paredes colgaban cuadros de mujeres desnudas, pero a ella le gustaban los paisajes con puestas de sol, y una tarde llevó a su discípula para mostrarle un cuadro donde se veía un rebaño de ovejas debajo de un árbol dorado en el atardecer. Miss Hilton buscaba desesperadamente el paisaje, mientras estaban las dos solas esperando al pintor. No había ningún paisaje: todos los cuadros se habian convertido en mujeres desnudas, y el hermoso peinado con trenzas lo tenía una mujer desnuda en un cuadro recién hecho sobre un caballete. Delante de su discípula, Miss Hilton posó ese día más tiesa que nunca, contra la ventana, envuelta en su vestido de terciopelo.” (énfasis mío 17)

Miss Hilton parece tener la intención inconsciente de exhibirse y que la discípula vea los desnudos (su cuerpo desnudo), pero el impulso es reprimido en su conciencia. La negación, como mecanismo de defensa, no alcanza a impedir sus acciones, las cuales son objetivamente percibidas por los terceros. 
como se viene dando a lo largo del relato: al enfocar el punto de vista en una cuestión gramatical y semántica propone la posibilidad de que lo que no entendió Miss Hilton es que el enunciado que contiene una generalización ("maestras”) se refiere en realidad a un caso específico, ella. El distanciamiento que desea marcar la dueña de casa es tajante y la despersonalización, extrema. Miss Hilton es vista como un miembro más de una clase, carente de individualidad, indiferenciado, cuyo único calificante es la posesión o no de un sentido de pudor de acuerdo con las normas de la clase dominante. Por otra parte, también cabe la posibilidad de que el no entender se refiera específicamente a la palabra “pudor”. La ambigüedad lejos de presentar un problema, enriquece el texto. Sin embargo, la frase siguiente parece inclinar la balanza hacia la segunda lectura, que remite al ámbito semántico: ¿qué se entiende por “pudor”? Es evidente que la definición de Miss Hilton es muy distinta de la de la dueña de casa. De nuevo, la voz narrativa, a través de la modalización del enunciado de contenido metalingüístico sugiere la posibilidad de un error de percepción por parte de Miss Hilton. Al echar mano de la prosopopeya: “la palabra... nadaba... vestida” el enunciado relega la acción a la palabra mientras que Miss Hilton se vuelve su receptora. Una pequeña palabra, el pronombre “le” resulta económico y eficaz para marcar su rol pasivo y denotar la turbación de sus pensamientos: “la palabra pudor le nadaba en la cabeza”.

El vínculo entre la palabra “pudor” y el vestido de terciopelo verde aceituna remite a la escena en el estudio y al momento del descubrimiento de la falta: el reconocimiento ya ineludible para Miss Hilton de que la imagen de "una mujer desnuda” que tenía el peinado de trenzas no es sino ella. Cuando se enfrenta a la nota de despido, a 
la palabra escrita, el punto de vista del narrador se aparta en dirección opuesta al de Miss Hilton y parece quedarse con la versión oficial: aunque Miss Hilton lo niegue y esconda de su conciencia los hechos reprobables o no los considere como tal, la palabra escrita los fija en el plano consciente. El encuentro con el "logos” destruye la imagen del yo. Con la introducción de la ley aparece la falta. Como en el relato edénico, el conocimiento del bien y del mal acarrea la asunción de responsabilidad, la vergüenza por la infracción de la norma y la consecuente expulsión del infractor. La palabra le abre finalmente los ojos y Miss Hilton logra conocerse, verse de una forma más auténtica, completando su percepción hasta ese momento sesgada: "Sintió crecer en ella una mujer fácilmente fatal” (calificativo que deviene por asociación a la imagen de la mujer desnuda del cuadro y repetición del adverbio que califica al principio la capacidad su capacidad de sonrojarse). Lo que sólo se había sugerido indirectamente acerca de la conducta de Miss Hilton a partir de su descripción física, del relato de sus experiencias y de los hechos narrados, es afirmado por la voz narrativa focalizada internamente, desde la conciencia del personaje. La expulsión del círculo familiar queda mediatizada por una comparación que casi resulta cómica: "y se fue de la casa con la cara abrasada, como si acabara de jugar un partido de tenis”. (17) La voz narrativa parece querer buscar el equilibrio entre la connotación negativa de la primera frase (mujer fácilmente fatal) con una imagen inocua, saludable, positiva, (partido de tenis) en el segundo. Además parece querer anular el referente negativo de "la cara abrasada": (17) no sería la vergüenza sino una reacción natural del cuerpo teniendo en cuenta que en el inicio del relato uno de los primeros datos de la descripción de Miss Hilton es que “se sonrojaba fácilmente”. (16) De nuevo, ese vaivén entre dos posibilidades, dos puntos de vista, de la voz narrativa deja traslucir la lucha 
interna del personaje que se debate entre el peso del conocimiento y la necesidad de disfrazar ante la mirada del otro la verdadera causa de lo que denota su rostro. Sin embargo, la llegada del logos, del conocimiento, convierte ese mecanismo de defensa en una acción consciente, en una elección y el ocultamiento, en mentira. El personaje pierde la inocencia presunta o real (si bien el lector duda de que la haya tenido) y cualquier intento de negación ya será autoengaño.

A pesar de ello, el cuento vuelve a oscilar hacia el punto de vista de Miss Hilton en reacción (en lugar de acción) a las circunstancias. De regreso a la escena de la mercería, un objeto concreto le recuerda los hechos que está tratando de olvidar encarando una actividad banal, concentrándose en divagaciones sobre los objetos que tiene delante: “Al abrir la cartera para pagar las horquillas, se encontró con la tarjeta insultante que se asomaba todavía por entre los papeles, y la miró furtivamente como si se hubiera tratado de una fotografía pornográfica.” (énfasis mío 18). El verbo reflexivo marca y refuerza nuevamente su papel de receptora de la acción. Mediante la prosopopeya, la tarjeta es el sujeto que lleva adelante la acción, la cual, por tratarse de una acción continua parece un fantasma que sigue al acecho. Irónicamente, la voz narrativa consigna la última acción de Miss Hilton en voz activa: “la miró”, refiriéndose a la nota. Ahora bien, la "insistencia" de la nota que "se asomaba todavía por entre los papeles”, eco de la “insistencia” de los pintores, logra su cometido: que Miss Hilton actúe, que deje la pasividad para convertirse en agente, en protagonista de su destino. En esa mirada furtiva, de reojo hay una asunción de agencialidad revelada en la comparación: Miss Hilton sabe cómo se mira una fotografía pornográfica; ¿̇o es la voz 
narrativa quien posee el conocimiento y se lo atribuye a Miss Hilton, es decir, sorprende en ella un gesto conocido? El vaivén de la focalización continúa ad nauseam.

Tras la conmoción que le produce el despido, en retrospectiva el lector adquiere una nueva dimensión del relato ya que entiende ese estado de absorción que se describía al inicio: "Se encontró en la mercería El Ancla, comprando alfileres y horquillas para sostener sus finas y largas trenzas enroscadas alrededor de la cabeza”. (énfasis mío 17) La segunda lectura completa ese espacio de indeterminación que parecía dejar a ese enunciado sin aparente correlación. Esto demuestra una vez más que ningún elemento constitutivo u ordenamiento del relato ocampeano está librado al azar, o es gratuito. Así, otro detalle descriptivo que parece estar de sobra: "Las vidrieras de las mercerías le gustaban por un cierto aire comestible que tienen las hileras de botones acaramelados, los costureros en forma de bomboneras y las puntillas de papel. Las horquillas tenían que ser doradas” encuentra otra función esencial. (17) La digresión intenta desviar la atención del lector hacia el detalle trivial por analogía con el pasaje descriptivo del inicio (“Le gustaban más que los canales las calles angostas, de cementerio, de Venecia”) por un lado, para demorar el avance de la acción hacia el desenlace; y por el otro, para expresar el estado mental del personaje que no acaba de asimilar los motivos de su despido para no admitir su responsabilidad, con las profundas ramificaciones que ello implica y, por ende, trata de evitar el asunto, intentando ocupar su mente en algo trivial.

El intento de enfocar la mirada en los objetos de la mercería, objetos irrelevantes, es coartado por la irrupción en el plano visual de la tarjeta con la palabra “pudor” y la acusación que supone y las consecuencias que despliega. Así, el tema de la mirada, "la 
imagen acusatoria por excelencia, clásica inhibidora de la intimidad” (Matamoro 216), aparece en el texto expresando ambos significados y en contraposición al tema de la negación o “privación de la vista”, aplicada selectivamente en el caso del personaje. Miss Hilton abre y cierra los ojos demostrando que ve (entiende) y a la vez no queriendo ver la imagen que de sí le devuelve el otro. La mirada insistente de los pintores, la discípula, la tarjeta con la palabra “pudor” la fuerzan a abrir los ojos que eligió cerrar ante el desnudo, imagen del despojo, de la autenticidad, de la verdad sobre sí misma para no reconocerse en "una mujer” "fácilmente fatal”.

Para capturar en plenitud la dualidad y ambivalencia del personaje, tanto en la percepción de su imagen como en su conducta, nada mejor que un elemento que personifica esa dualidad y ambivalencia: el terciopelo, material que en su unidad ofrece al sentido del tacto dos sensaciones distintas según la dirección en que se toque. La suavidad y la aspereza en una misma tela es símbolo de la convivencia de un ser dual bajo la misma piel y entronca con la imagen de los ojos que, abiertos o cerrados, internalizan o niegan la realidad.

La mención del terciopelo, en conexión con el vestido verde aceituna que da título al cuento, es otro de los rasgos interesantes de la narración y la creación del personaje. Está claro que cada mención que se haga no es gratuita sino que constituye un elemento clave tanto en lo estructural como en lo simbólico. Así, focaliza la mirada en la vestimenta y problematiza la percepción del yo según su relación con el cuerpo en torno a la oposición mostrar-ocultar. La tela espesa envuelve y cubre el cuerpo, pero el verdadero yo no puede resistir por mucho tiempo el atavío y se exhibe, se muestra por entre el 
tramado como si fuera "papel manteca” y deja traslucir lo que está envuelto. Muestra reacciones, oculta motivaciones pero, paradójicamente, las oculta de sí misma. Por otro lado, resulta una metáfora muy fructífera para subrayar la dinámica de la focalización de los puntos de vista de la voz narrativa y del personaje en cuanto a la oposición ser-parecer y la construcción de un relato polifónico. Asimismo, el terciopelo, como material del vestido se convierte en un punto de coincidencia con las historias seleccionadas para este apartado, además, claro está, del papel que juega el vestido como elemento simbólico en común. Este detalle no es menor cuando se lee este cuento que aparece en el primer volumen, tan injustamente denostado por gran parte de la crítica ocampeana, como germen de los posteriores, en cuanto a experimentación formal, temática y estilística. El terciopelo como símbolo de ambivalencia participa de la cualidad de la narración y de la cualidad del personaje: de un lado es suave y del otro es áspero y el contacto produce repulsión, cubre el cuerpo pero marca su forma.

Al detenerse en el detalle del vestido que Miss Hilton lleva al estudio del pintor se pone en juego el símbolo del terciopelo con sus características propias y se refuerza la idea de que por contigüidad, propiedad mágica de los objetos, le infunde alguna de sus cualidades al cuerpo que recubre. Así, la naturaleza ambivalente del género se trasladará a la conducta de doble cara de Miss Hilton, aun cuando, ésta no sea consciente de ello, o bien finja no serlo. Invirtiendo la dirección de los impulsos es también factible concebir el terciopelo como una “segunda piel”, expresión de la dualidad del personaje.

Como se verá en los cuentos posteriores, particularmente en "El vestido de terciopelo”, la característica del paño de adherirse al cuerpo hasta casi constituir una 
segunda piel se vuelve letal para la Cornelia Catalpina. En el caso de Miss Hilton, la doble cara del paño no le acarrea consecuencias tan trágicas. Sin embargo a nivel simbólico, el “exilio” de Miss Hilton, que le supone la pérdida de confianza de la clase dominante, equivale a la muerte social. Una vez que la reputación de una institutriz queda manchada ya no será contratada por ninguna familia en posición de hacerlo. (Igual suerte, la remoción de su cargo, corre Miss Fielding en “El diario de Porfiria Bernal” al contravenir las normas del decoro en su trato con el señorito hermano de Porfiria). A pesar de no conllevar consecuencias físicas, el grado de fracaso para quien no se sabe culpable o, mejor dicho, no quiere saberse culpable, genera en el lector un cierto grado de lástima por el personaje que está en negación. El final del relato cierra el círculo de la lectura actualizando el hecho de que Miss Hilton incurrió en una falta según la norma social y debe pagar las consecuencias. Sin embargo, deja un final abierto en cuanto a la conducta del personaje de allí en adelante. La última impresión de Miss Hilton es la de una persona que todavía está conmocionada por las implicaciones de la acusación que se le atribuye y lo que esto significa para la imagen que tiene de sí. Sin embargo, por pequeña que sea, el relato no cierra la posibilidad de que se transforme en una experiencia liberadora, en una auto-afirmación que resignificaría la “expulsión” como una "huida” de un ambiente opresor hacia un espacio-tiempo más libre: una vuelta al motivo del viaje a lugares remotos y un regreso a los tiempos de libertad de la juventud. Lejos de la ley, el personaje puede volver a la acción. 
Rito, castigo y muerte en "El vestido de terciopelo"

"If you wear that velvet dress...” U2

El cuento "El vestido de terciopelo" aparece en La furia y otros cuentos en 1959, un volumen que se considera bisagra en la cuentística de Ocampo pues aparece diez años después de Autobiografia de Irene, un contario muy distinto, de filiación más borgeana, del cual la autora se aparta en lo sucesivo. Es decir, con La furia, Ocampo vuelve a las preocupaciones estéticas, temáticas y formales que esbozó en Viaje olvidado dispuesta a infundirle nuevos bríos y hacer un nuevo intento, esta vez, más logrado, según la opinión de muchos.

Volviendo a la modalidad del fantástico, Ocampo introduce un tema más “pequeño burgués”: la prueba de un vestido que una señora bien le encargó a una modista de clase humilde, episodio que termina con la muerte de la señora asfixiada por el vestido. Sin embargo, un argumento que puede ser tildado de trivial, en manos expertas se convierte en una mordaz crítica social vestida de humor en la que no falta la tragedia. ${ }^{31}$

El cuento ha sido comentado desde distintas lecturas críticas. Uno de los rasgos sobresalientes es el juego de símbolos el dragón y el terciopelo que aluden a los significados ocultos que esas imágenes evocan y que proponen una lectura psicoanalítica. Concebido como expresión de la femineidad, del deseo, la señora bien sólo lo deja como elemento decorativo en lugar de apropiarse de su fuerza.

\footnotetext{
${ }^{31}$ Ulla comenta a propósito de este cuento: "la sátira castiga la fatuidad de una señora de clase acomodada en "El vestido de terciopelo" (La furia)”. (Invenciones 267)
} 
-¡Qué vestido! Creo que no hay otro modelo tan precioso en todo

Buenos Aires -dijo Casilda, dejando caer un alfiler que tenía entre sus dientes-. ¿No le agrada, señora?

-Muchísimo. El terciopelo es el género que más me gusta. Los géneros son como las flores: uno tiene sus preferencias. Yo comparo el terciopelo a los nardos.

-¿Le gusta el nardo? Es tan triste -protestó Casilda.

-El nardo es mi flor preferida, y sin embargo me hace daño.

Cuando aspiro su olor me descompongo. El terciopelo hace rechinar mis dientes, me eriza, como me erizaban los guantes de hilo en la infancia y, sin embargo, para mí no hay en el mundo otro género comparable. Sentir su suavidad en mi mano, me atrae aunque a veces me repugne. ${ }^{32}$ ¡Qué mujer está mejor vestida que aquella que se viste de terciopelo negro! $\mathrm{Ni}$ un cuello de puntilla le hace falta, ni un collar de perlas; todo estaría de más. El terciopelo se basta a sí mismo. Es suntuoso y es sobrio. ${ }^{33}$ (OCI 251-2)

\footnotetext{
${ }^{32}$ Mancini trae a colación una observación de Ocampo sobre el objeto cursi que encuentra paralelo en esta descripción manifestando de igual manera "en términos de fascinación y repulsa la protección de la utilería kitsch;” uno de cuyos peligros es

la manipulación a la que el sujeto queda expuesto si es dominado por los sentimienos: ... La cursilería siempre me atrajo, es una forma del horror. No puedo dejar de mirar los objetos cursis, me causan gracia y me horripilan al mismo tiempo. Son peligrosos. Cuando uno introduce la cursilería en un cuento para reírse de ella, corre el riesgo de que todo lo que ha escrito se vuelva cursi. (Escalas 51)

${ }^{33}$ En este discurso ambivalente se manifiesta el kitsch que, según observa Mancini, reúne "la belleza y el enigma” y "el rasgo amenazador...: el riesgo de ser fagocitado por esa relación aparentemente placentera
} 
La primera imagen: el terciopelo es ambivalente. En su obra fundacional, $L a$ interpretación de los sueños, Freud señala la conexión simbólica entre el terciopelo y el vello público: "The associations velvet and moss distinctly point to crines pubis." ${ }^{34}$ (sp)

La segunda imagen, el dragón, es por demás rica en alusiones dado que constituye una figura simbólica universal, que se encuentra en la mayoría de pueblos del mundo, tanto en las culturas primitivas y orientales como en las clásicas. (Cirlot 178) El Diccionario de símbolos consigna en detalle su morfología, presencia y significado a partir de variadas fuentes y tradiciones. Así, en cuanto a los rasgos morfológicos más sobresalientes:

confabulación de elementos distintos tomados de animales especialmente agresivos y peligrosos, serpientes, cocodrilos, leones ... El dragón es, en consecuencia, "lo animal" ... como "adversario", en el mismo concepto que luego se atribuyó al diablo. ... En multitud de leyendas... aparece con ese significado de enemigo primordial. Del aspecto simbólico de algunas leyendas, los dragones significan plagas que perturban ... a la persona si el símbolo deviene psicológico ... [E]l dragón es símbolo de enfermedad ... Los autores clásicos y la Biblia lo mencionan con mucha frecuencia... Del lado bíblico, se exagera el carácter negativo del símbolo...

cordial que se establece entre el hombre y su contorno. Un estado de alienación para quien se entrega confiado a lo efimero del consumo". (Escalas 51 )

${ }^{34} \mathrm{La}$ interpretación corresponde al sueño de una mujer en el que aparece arreglando un centro de mesa con flores para una celebración de cumpleaños. El terciopelo aparece en la descripción detallada del arreglo como uno de los elementos finales unido al musgo y, por ende, con mayor fuerza simbólica. El caso se analiza en el capítulo VI. “The dream-work”, sección "E. Representation in Dreams by Symbols: Some Further Typical Dreams", bajo el apartado "8. The question of symbolism in the dreams of normal persons.” (edición en línea: http://www.psywww.com/books/interp/chap06e.htm) Fecha de acceso: 15 oct. 2014. 
La actual psicología define el símbolo del dragón como "algo terrible que vencer" pues sólo el que vence al dragón deviene héroe.

El dragón universal (katolikos ophis), según los gnósticos, es el "camino a través de todas las cosas". Se relaciona con el principio del caos (nuestro Caos o Espíritu es un dragón ígneo que todo lo vence. Flalete, "Introitus") y con el principio de la disolución...El dragón es la disolución de los cuerpos (textos del seudo Demócrito).

Entre los símbolos de esa disolución, el hermetismo usa las expresiones siguientes: veneno, víbora, disolvente universal, vinagre filosofal = potencia de lo indiferenciado (Solve).

Se trata todavía de un dragón que debe ser vencido y muerto: es aquello que se devora eternamente a sí mismo, el Mercurio como sed ardiente, como hambre e impulso de ciego goce. (178)

A partir del relevamiento del significado, se ve que predominan las connotaciones negativas. Sin embargo, también representa un aspecto positivo en ciertos contextos:

Puede aparecer entronizado y casi deificado; [como] en los estandartes chinos de la dinastía manchú...

son fuertes y vigilantes, su vista es agudísima y parece ser que su nombre procede de la palabra griega dercein (viendo). Por esta razón, en plena 
ambivalencia, los hicieron — como a los grifos—guardianes de templos y

tesoros y también alegoría del vaticinio y la sabiduría...

China es posiblemente el lugar donde el dragón ha alcanzado una mayor

difusión y transfiguración incluso. Es el emblema del poder imperial.

Según Diel, el dragón genérico chino simboliza la perversión sublimada y

superada, pues, implícitamente se trata de un "dragón domado" como el

que obedece a San Jorge de pues de haber sido derrotado por el santo.

Otra imagen que refuerza la interpretación de la prueba del vestido como rito religioso es el nardo ${ }^{35}$. Asociada desde la antigüedad a las ceremonias religiosas, es símbolo de pureza, de amor infinito y de sacrificio. Es llamativo el significado que adquiere en el relato bíblico: el de un amor sin precio y el de profecía de la pasión y

\footnotetext{
${ }^{35}$ Castronovo, Filippa. "Il profumo di nardo". http://www.paoline.it/articoloRubrica_arb1717.aspx (Fecha de acceso: diciembre 2014). Filippa Castronovo explica el origen y significado del perfume de nardo: Il nardo è un olio profumato di altissimo valore. Nella Bibbia è simbolo dell'amore fedele fino a dare la vita. Un semplice vasetto di questo olio profumato, infatti, costava più di trecento denari, quasi quanto lo stipendio annuale di un salariato. Per tale motivo nella Bibbia il profumo del nardo esprime l'amore che non ha prezzo e si realizza diffondendosi. Il simbolo del profumo del nardo, che scaturisce dal vaso spezzato, appare anche nei Vangeli e interpreta, in modo eccellente, il significato della passione e morte di Gesù come effusione di un amore senza misura ed esprime anche la sua risurrezione, come amore che vince la morte. [El nardo es un aceite perfumado muy valioso. En la Biblia es símbolo del amor fiel hasta el sacrificio de la vida. Un simple frasco de este aceite perfumado, de hecho, costaba más de trescientos denarios, casi el equivalente al salario anual de un trabajador. Por tal motivo, en la Biblia el perfume de nardo expresa el amor que no tiene precio y se realiza al difundirse. El símbolo del perfume de nardo, que emana del frasco quebrado, parece también en los Evangelios e interpreta, de excelente manera, el significado de la pasión y muerte de Jesús como emanación de un amor sin medida y expresa también su resurrección como un amor que vence la muerte.] (mi traducción)
} 
muerte de Jesús. ${ }^{36}$ El perfume de nardo puro, era un ungüento que se utilizaba en los ritos funerarios judíos para preparar el cuerpo para la sepultura ${ }^{37}$. De allí su presencia en los ritos y ceremoniales de la religión católica en forma de ofrenda floral para los altares que hacen parte de la liturgia o su empleo la iconografía hagiográfica.

La lectura del cuento, que abunda en detalles humorísticos, casi absurdos, por momentos esconde en su centro un conflicto de clases: la pequeña burguesía de nuevos ricos, con su indolencia y despilfarro frente a la clase humilde y trabajadora que les brinda servicios. La tensión disimulada estalla en el hecho culminante de la muerte de la señora bien a partir de la irrupción de un elemento fantástico: la señora muere estrangulada por su vestido cuyo dragón bordado parece cobrar vida. A este propósito resulta útil la afirmación que Murillo-Chinchilla recoge de Todorov acerca de que "lo fantástico permite franquear ciertos límites inaccesibles mientras no se recurra a él”, (Todorov 164); en otras palabras, bajo la categoría de fantástico, la autora puede poner en escena situaciones que, de otra forma, serían censuradas (68). En este caso, la muerte (el

36 "Nella Bibbia il profumo del nardo esprime l'amore che non ha prezzo e si realizza diffondendosi. Nei Vangeli assume il senso di profezia della passione e morte di Gesù” (Castronovo s/p) [En la Biblia el perfume de nardo expresa el amor que no tiene precio y se realiza en la entrega. En los Evangelios asume el sentido de profecía de la pasión y muerte de Jesús] (mi traducción)

${ }^{37}$ Los eruditos bíblicos señalan que, sobre la base de las costumbres judías, el perfume que se menciona en el siguiente pasaje es de nardo puro y viene en un recipiente hermético de alabastro que es de uso único pues se quiebra para vertir el perfume:

Mientras Jesús comía, llegó una mujer con un frasco de perfume muy caro. La mujer se acercó a Jesús y derramó el perfume sobre su cabeza. Los discípulos se enojaron y dijeron:

— ¿Qué desperdicio! Ese perfume pudo haberse vendido, y con el dinero hubiéramos ayudado a muchos pobres. Jesús los escuchó, y enseguida les dijo:

- No critiquen a esta mujer. Ella me ha tratado con mucha bondad. Cerca de ustedes siempre habrá gente pobre, pero muy pronto yo no estaré aquí con ustedes. Esta mujer derramó perfume sobre mi cabeza, sin saber que estaba preparando mi cuerpo para mi entierro. (San Mateo 26:7-12 La Biblia: Traducción en lenguaje actual) 
asesinato) de la señora bien a manos del vestido hecho por la costurera y la falta de empatía y compasión por parte de la modista y su amiga que dan paso al humor negro.

Una lectura desde la dialéctica hegeliana del amo y del esclavo y la obra de teatro “Las criadas” de Genet, que propone Mancini, ilumina las relaciones de poder y saca a la luz los impulsos que mueven a los personajes, la modista, representando el rol de esclava (criada) y la señora, en el rol de amo, cuyos gestos y señales criados pueden alinearse en ciertas lógicas del crimen cuyas realizaciones infieren saberes y políticas afines: ${ }^{38}$

La traición tiene una lógica que se constituye con el saber de la proximidad y la política de la distancia, además de un saber de la existencia, con la política de la persistencia y un saber del simulacro con la política de la apariencia... [T]anto en la versión de Genet como en las

${ }^{38}$ El análisis de Mancini se centra primero en la articulación de estas políticas en la obra de Genet: El saber de la existencia con su política de la persistencia, estaría implícito en el trabajo minucioso de las criadas que «hacen» las criadas para colmar su deseo; tanto el de «envenenar» a sus amas en el caso de Genet y Victoria o su revés, el de cuidarla hasta hacerla inmortal, en el caso de Silvina. Los otros dos saberes de la lógica de la traición, el del simulacro con su política de la apariencia y el de la proximidad con su política de la distancia, tomarían cuerpo en el ritual cotidiano que representan las criadas de Genet, «la ceremonia», como ellas mismas la denominan. Es claro el uso del disfraz para travestirse, Clara en la señora y Solange en Clara, y el travestismo se abisma ... porque Genet en sus indicaciones teatrales señala que los actores tienen que ser hombres que representen a los personajes femeninos.

La política de la distancia es constitutiva de toda ceremonia. En la representación ritual, el personaje de Clara que hace de la señora, le dice con firmeza a Solange que hace de Clara, que no se acerque que mantenga su distancia; los cuerpos no deben rozarse. Por su parte, la ceremonia se emparenta con la muerte, el crimen proyectado hacia el ama se desplaza y recae sin posibilidad de desvío en el ama travestida que es la criada; no hay forma de evitarlo. La ceremonia es destino, es fatalidad, no hay valores que puedan instituirse, ni metáfora ni alegoría. Sólo hay reglas que hay que cumplir, y sobre todo, la ceremonia nace a partir de la violencia. Es una violencia infringida a la representación o a la realidad. En el caso que nos ocupa, y recurriendo a las disimetrías planteadas en la búsqueda de la verdad, la violencia surgiría como la resultante inmediata del reconocimiento dispar, es decir, cuando el sujeto no es reconocido como tal, sino como un objeto; y la ceremonia permite la conformación de un espacio ilusorio, una ilusión escénica sin espectadores que se abandona al puro desenvolvimiento de los hechos que desembocan en el crimen. (“Amo y esclavo” 84) 
versiones de las Ocampo, entre amas y criadas se impone una lógica de la traición con sus respectivos saberes y políticas. (“Amo y esclavo” 83-84)

En "El vestido de terciopelo", el ama muere “a manos” de la criada-modista pues el crimen lo provoca el vestido, objeto que es producto del trabajo de la criada, “de otro modo y en términos de Lacan, el resultado de esa espera de la Muerte del Amo”. ${ }^{39}$

\section{Como explica Mancini:}

el vestido de terciopelo se animiza y va asfixiando a la señora hasta que la mata, y la muerte tiene lugar en esa escena ilusoria, ritual, ceremoniosa, que crean las mujeres frente al espejo probándose los ropajes a medio hacer, pero proyectándolos a la escena real: el momento en que lo usarán en viajes o fiestas. La política de la distancia, condición de la ceremonia, y que integra la lógica del traidor, podría darse en el cuento a través de un artificio lingüístico. Un Leitmotiv -¡Qué risa! ¡Qué risa! ¡Qué risa!- puesto en boca de una niña [amiga] de la criada, que acompasa los sucesivos pasos de la ceremonia mortuoria y además, la cierra anulando la distancia. El “¡Qué risa!” de la pequeña criada y la muerte de la señora se unen para

\footnotetext{
${ }^{39}$ En el análisis de "Las criadas” y los caminos que desembocan en el crimen queda una pregunta obligada: por qué surge el deseo de la muerte del amo; la respuesta la ofrece Lacan y la plantea en términos de «coartada» del esclavo: «el trabajo al que se ha sometido el esclavo renunciando al goce por temor a la muerte será la vía por la que realizará su libertad. El esclavo no se engaña creyendo encontrar el goce en el trabajo y encuentra su coartada en la muerte del amo». El criado, mientras realiza sus minuciosas tareas, espera la muerte del amo, la desea o la provoca ficcionalmente. Aparece así el «hacer» del esclavo, su «trabajo» en función de la vida -el amo consume los productos de sus siervos- y de la muerte -el siervo espera paciente la muerte del amo. (“Amo y esclavo” 84)
} 
terminar la ceremonia y el cuento, y subraya la ausencia de valores, de metáforas o alegorías. (86)

“El vestido de terciopelo” fue adaptado por Liliana Morello y César Repeto para la serie de la televisión argentina “Cuentos de película” compuesta por episodios de una hora y que salió al aire en 2001. (Antes, en 1996, Morello había adaptado el material para un cortometraje de veinte minutos que no llegó a realizar.) ${ }^{40}$ Según lo explica Morello, más que una adaptación se trata de una transposición ${ }^{41}$ que propone una lectura del cuento original, enriquecida con elementos sacados de otros cuentos de la escritora. “Ofrece un enfoque sintético que revela las apuestas socio-culturales de los juegos paródicos que caracterizan la escritura fantástica de Silvina Ocampo.” (185)

${ }^{40}$ Morello se detiene en rememorar la reacción que le produjo la lectura de los cuentos de Ocampo. Sus palabras expresan la impresión que bien podría ser la de la mayoría de los lectores de Ocampo: Ya no pude dejar de leerla y releerla. Su lectura siempre se convierte en una aventura, en un juego irresistible y divertido. Para mí, sus cuentos no se agotan y siempre descubro en ellos algo nuevo. Es así, que atraída por sus historias, en 1996, junto a este mismo amigo, [el escritor Tulio Stella, a través de quien conoció la obra de Ocampo] decidí adaptar uno de sus cuentos, "El vestido de terciopelo" (La furia y otros cuentos, 1959), para hacer un cortometraje, que finalmente nunca llegué a realizar. (178)

${ }^{41}$ A propósito del proceso que supone trasladar un cuento al lenguaje del cine Morello puntualiza: Compartiendo los conceptos vertidos por Francis Vanoye, en su libro Scénarios modèles, modèles de scénarios (París, Nathan, 1991), nuestro trabajo, más que de una adaptación se trataría de una transposición,

Partiremos del principio aquel de que la adaptación es, ante todo, un hecho (un hecho, además, impuesto por la necesidad: el cine necesita historias, temas; los guiones se nutren de otras obras). Toda adaptación consiste en transponer una forma de expresión a otra. Esta traslación forzosa sitúa al guionista adaptador ante unos problemas que clasificaremos según tres categorías (no impermeables, por supuesto): problemas técnicos, opciones estéticas y procesos de apropiación. (179) 
Agencialidad del deseo y subversión en "Las vestiduras peligrosas"

“El terreno del erotismo es esencialmente el terreno de la violencia, de la violación.”

Georges Bataille

El cuento "Las vestiduras peligrosas" aparece en Los días de la noche publicado en 1970. Será éste el volumen que abra un hiato en la publicación de la narrativa ocampeana ya que, durante la década del setenta, se publica una colección de poemas y cuentos y poemas para chicos. Habrá que esperar hasta 1984 para ver la antología Páginas de Silvina Ocampo seleccionadas por la autora y hasta 1988 para el siguiente volumen de cuentos $Y$ así sucesivamente ${ }^{42}$. La fecha de publicación no es un dato menor en el sentido de que el contexto social del momento está marcado por los acontecimientos posteriores al Mayo Francés y las manifestaciones del movimiento de liberación femenina en los EE.UU. que ofrecen un panorama distinto, en mutación, respecto del volumen precedente, La furia (1961).

El título del cuento, a través de la connotación negativa del adjetivo "peligrosas", conlleva una advertencia y desencadena una serie de expectativas para el lector que se verificarán como ciertas en el transcurso de la mayor parte de la narración. A partir de la advertencia del título, el acto de lectura se convierte en una pesquisa, en una investigación, juego que propone la autora, acerca de dónde reside el peligro. Además de esa primera advertencia nada velada, que intriga, pero no exige mayor esfuerzo en su reconocimiento, se le suma la referencia intertextual que supone "El vestido de

\footnotetext{
${ }^{42}$ La antología Páginas de Silvina Ocampo incluye selecciones de sus poemarios y contarios publicados hasta el momento y el relato, entonces inédito, "Y así sucesivamente" que dará título al contario publicado luego, en 1987.
} 
terciopelo” para un lector conocedor de la obra de Ocampo y que dispara la anticipación de la tragedia. ${ }^{43}$ El juego no queda reservado solamente al lector implícito sino que también se extiende al siguiente nivel de lectura que supone el análisis del cuento en tanto a objeto artístico a partir del aparato crítico-literario pues el locus del peligro es uno de los temas que se propone como materia de estudio.

En un rasgo típico de la acción ocampeana, la narración comienza in media res con una enunciación en primera persona. Este rasgo remite a varios cuentos de la autora (algunos incluidos en este estudio) que ponen en marcha el "discurso del yo”, del que la autobiografía, la confesión o la confidencia son ejemplos paradigmáticos. Sin preámbulo y sin marco estructurante, una voz habla sobre sí, en una especie de monólogo. La falta de encuadre narrativo acorta la distancia con el lector, que se adentra de lleno en lo que constituirá una confesión. Al igual que en "Voz en el teléfono" el lector se convierte en un “escucha” invisible, es decir, que no está marcado en el texto. "Lloro como una Magdalena cuando pienso en la Artemia, que era la sabiduría en persona cuando charlábamos.” (OCII 34) Con su habitual economía de estilo, Ocampo no deja nada al azar: en la misma oración las formas verbales en presente y pretérito indefinido marcan el rumbo que seguirá la narración del presente enunciativo al pasado desde el punto de vista y la experiencia de la primera persona. Las marcas léxicas del habla popular están presentes también: el uso del artículo definido "la” antepuesto al nombre propio

\footnotetext{
${ }^{43}$ Tanto el vestido de terciopelo como el vestido verde aceituna de los cuentos homónimos bien pueden recibir el mismo calificativo de ser "peligrosos" en sentidos afines y particulares. En "El vestido de terciopelo", el título es neutro y sólo el desarrollo de la trama lo expone como el instrumento de la muerte de la protagonista, Cornelia Catalpina. El vínculo del peligro con el "Vestido verde aceituna" es más laxo, ambiguo, sutil: es un sentido que se construye a partir de la trama y a nivel temático. Como segunda piel de la protagonista, símbolo de “una mujer fácilmente fatal” (CCI 17).
} 
“Artemia”, por un lado, y el uso de expresiones petrificadas o clichés "llorar como una Magdalena” caracterizan indirectamente a la voz narrativa como personaje perteneciente a la clase popular, además del tono de exageración que se desprende de la frase "que era la sabiduría en persona cuando charlábamos”. En el siguiente enunciado: “Podía ser buenísima, pero hay bondades que matan, como decía mi tía Lucy” (34) se repiten los lugares comunes (con variantes) y la alusión a la sabiduría popular “como decía mi tía Lucy”, conducta típica o estereotipo del personaje popular. El siguiente enunciado, “Lo peor es que por más que trate, no puedo describirla sin quitarle algo de su gracia”, (34) se caracteriza por la naturalidad de la expresión y sugiere un rasgo de candidez (que resultará importante para la interpretación del relato que se le pide al lector). Ante su imposibilidad de describirla con gracia, la voz recurre a la cita del discurso directo, un diálogo en el que aparece el nombre de la persona que enuncia: "Me decía: —Piluca, haceme un vestido peligroso.” (34) En pocas líneas, la autora proporciona sin estridencias datos claves acerca de los personajes: sus nombres, la relación que los une (o, mejor dicho, los unía) y rasgos descriptivos de sus sentimientos, personalidad e idiosincrasia. Además de caracterizar indirectamente a la voz narrativa que se identificará con Piluca, la autora esconde en el discurso del personaje palabras que acumulan connotaciones negativas (“lloro”, “matan”, “peligroso”), que, en forma solapada, sugieren al lector asociaciones útiles para la interpretación del cuento y para anticipar una tragedia. Al estar dentro de las expresiones estereotipadas, estos términos quedan escondidos a plena vista y sólo actualizarán su significado y connotación plenos una vez que se cierre el relato. Por otro lado, aparece en esta escena el anclaje con el título del cuento: un vestido peligroso, obra de una y propiedad de la otra. 
Se ha observado en Ocampo la ubicuidad del recurso al estereotipo en la caracterización de los personajes. Así opera en este cuento con la variante de profundizar la constitución del narrador no fidedigno mediante este recurso y de dosificar la información que permite desenmascararlo como tal. Además de constituirse en una de las marcas de exageración o expresión hiperbólica, el enunciado "Lloro como una Magdalena cuando pienso en la Artemia, que era la sabiduría en persona cuando charlábamos” (34) es suceptible de una lectura más llana como ejemplo del discurso elogioso que típicamente se pronuncia acerca de los muertos: “Era tan bueno... Era tan buena...” Es rasgo del ser humano en general y de la cultura popular en particular no hablar mal de los muertos tendiendo a olvidar o minimizar defectos y faltas. Teniendo esto en cuenta, la expresión “Podía ser buenísima pero hay bondades que matan” (34) se tiñe de ambigüedad en cuanto al referente ayudada por la identidad de las formas verbales de primera y tercera persona. En una lectura llana, el "podía ser buenísima” se identifica con "la Artemia”. Pero una lectura suspicaz permite relacionar al sujeto de la oración con el de la enunciación, Piluca, con quien se relaciona el sintagma “como decía mi Tía Lucy”. La ambigüedad no se resuelve pues la conjunción adversativa "pero” va seguida de una expresión impersonal "hay bondades que matan” que distancia a cualquiera que fueren los sujetos del primer verbo de la objeción sutil que este enunciado plantea. Así, quien llora “como una Magdalena” a causa de una muerte puede estar movida por el dolor (reacción natural ante la pérdida de un ser querido), la compasión (cuando se trata de la pérdida de otro) o bien por la culpa (cuando existe un grado de responsabilidad en relación con la muerte). Asimismo, quien es "buenísima” y "la sabiduría en persona” 
puede ser capaz, de perjudicarse o perjudicar a otro (“que matan”) o incluso, literalmente de matar, por "exceso de bondad" o "simulando bondad".

Ocampo observó que el principio de un relato tanto como su final son los que más trabajo llevan. En éste como en otros ejemplos que se estudiaron queda por demás evidente ese cuidado que la autora pone en cada una de sus creaciones. Del mismo modo, el relato de Piluca dosificará la historia de las vestiduras peligrosas: diseños de Artemia y confecciones de Régula con un solo propósito, el de exhibirse y ser violada. El suspenso va in crescendo a medida que los vestidos creados por Artemia y cosidos por Piluca se vuelven cada vez más osados, más reveladores, más transgresores. Sin embargo, las expectativas del lector se ven una y otra vez frustradas al comprobar, junto con la protagonista, que ningún vestido logra su cometido: la violación de la portadora. Es más, en cada ocasión, Artemia vuelve a decepcionarse cuando las noticias de los diarios confirman el hecho de que, en lugares remotos, una mujer vestida con un atuendo idéntico al de ella ha sido víctima de violencia y agresión sexual. Silvina Ocampo escribió en otros cuentos y poemas sobre el don inútil, aquél que no surte el efecto deseado por el poseedor (tal es el caso, por ejemplo, de Irene, la clarividente que puede anticipar el futuro pero no recordar el pasado, en el cuento "Autobiografía de Irene”, o la facultad de Leopoldina de extraer objetos de sus sueños pero nunca los objetos de valor que le piden sus parientes, en "Los sueños de Leopoldina”). En el caso de Artemia, su obra y el fin que conlleva, sólo se actualiza cuando son apropiados por otras. Puede extraerse de esto un comentario autorial acerca del proceso creativo en materia literaria en tanto que la creatividad y la originalidad, como búsqueda de la libertad y la expresión 
personal, son criticadas y recibidas con perplejidad por parte del entorno mientras que la apropiación, la imitación de la obra de otros en otros contextos sí logra la consagración como objeto de arte.

Uno de los elementos perturbadores del relato es la definición de "violación”.

violar. (Del lat. violāre).

1. tr. Infringir o quebrantar una ley, un tratado, un precepto, una promesa, etc.

2. tr. Tener acceso carnal con alguien en contra de su voluntad o cuando se halla privado de sentido o discernimiento.

3. tr. Profanar un lugar sagrado, ejecutando en él ciertos actos determinados por el derecho canónico.

4. tr. Ajar o deslucir algo.

Atentos a la definición, el elemento determinante es el doblegamiento de la voluntad. En el cuento, este elemento está ausente pues Artemia va en busca del acceso carnal voluntariamente. El hecho de no obtenerlo es lo que produce su desasosiego. Desde la óptica feminista, el tema de la agencialidad y el deseo en este caso se vuelve problemático pues el valor positivo asignado a la agencialidad se contrarresta con la idea de un acto realizado en contra de la voluntad.

La dicotomía dentro/fuera se presenta de una manera diferente en "Las vestiduras peligrosas” puesto que aquí las protagonistas son dos mujeres. Una de ellas es Artemia, 
que busca el espacio exterior para liberar su sexualidad y la otra es Régula, que ejerce de conciencia de la primera y de las posibles lectoras y lectores, utilizando sentencias como "una habitación con utensilios no parece nada pero es todo en la vida de una mujer honrada” (104)

Los hechos de la trama remiten al orden fantástico. La transmigración del vestido y el logro de su cometido, provoca la ruptura del tiempo y del espacio, y de la causalidad del mundo narrado que presentaba los visos del mundo cotidiano. Así, la historia de una costurera y su clienta deja de ser trivial y cobra un matiz antirrealista. El hecho de que ciertos elementos se introduzcan en el relato como algo natural lo remite al cuento fantástico pues hacen vacilar al lector. Sin embargo la vacilación que Todorov exige en el género fantástico queda trastocada en este caso, pues los hechos sobrenaturales no tienen otra gravitación en el ámbito diegético que avanzar la trama y se aceptan como dados y naturales por parte de los personajes relegando el carácter sobrenatural o extraño a la percepción del lector a partir de su contexto (extradiegético, se entiende). Se produce así un choque con las expectativas del lector que debe ajustar sus saberes dados a los planteamientos del mundo narrado suspendiendo la incredulidad y aceptando el pacto lúdico que propone el autor.

[A diferencia de los relatos fantásticos que Todorov estudia en Le fantastique, o las elaboradas creaciones de Borges o Bioy Casares, que apuntan al juego intelectual, se apoyan en el enigma o buscan la perfección de la trama, los cuentos de Ocampo constituyen una propuesta más orgánica caracterizada por trazar líneas abiertas y puntos 
de fuga. Por lo tanto, utilizo el término “modalidades del fantástico” para definir los cuentos de Ocampo]

Al inscribir los hechos en el orden fantástico se practica un primer grado de remoción con respecto al orden social de su contexto, al cual se pretende criticar. El hecho de que los vestidos de Artemia aparezcan como por arte de magia en algún lugar del otro lado del mundo también viene dado. No se explica tampoco el motivo por el cual las mujeres se los ponen, es decir, si compartían el mismo objetivo que Artemia. El recurso de la elipsis es uno de los preferidos de Ocampo: las pausas, los silencios casi musicales, le den pie al lector para la producción de sentidos que completen el objeto estético.

La narración simplemente se limita a señalar que, a diferencia de Artemia, las mujeres que salieron a la calle con los vestidos sí fueron violadas y asesinadas, es decir, que se cumplió en ellas el fin que Artemia esperaba para sí.

Esto, además, deja en claro que la autora no emite un juicio de valor negativo con respecto a Artemia, es decir, no critica ni cuestiona sus acciones ni motivaciones. Al contrario, se enfoca, mediante un discurso de carácter objetivo, en las reacciones que le provoca la insatisfacción del deseo sin juzgar sobre su legitimidad. Nótese el empleo de un lenguaje llano, simple, en un estilo directo y “sin pelos en la lengua”. Textualmente no se ve una voluntad autorial en este sentido sino precisamente en el opuesto que desestabiliza las expectativas del lector: la que queda descalificada a través de la composición del discurso es Régula-Piluca, la “buena” de la historia. Mediante un procedimiento de satirización se trastocan los valores de la sociedad burguesa. 
Ocampo pone en boca de Régula-Piluca el discurso de la normatividad vigente, las reglas de la buena conducta de la sociedad burguesa. Irónicamente, la "voz del pueblo” dominado es la que se encarga de expresar y hacer cumplir las reglas de la clase dominante, en otro pliegue sobre sí del sistema axiológico que pone en juego Ocampo. Este hecho alude indirectamente a un episodio de la historia familiar que involucra a Fanny, la sirvienta de Victoria Ocampo, quien, según cuenta en su autobiografía, se convirtió en su cancerbero, al espiar sus movimientos e interferir en la relación con su amante.

El segundo grado de remoción se opera través del recurso del narrador en primera persona, que remite los hechos al filtro de su experiencia. Así los hechos truculentos no quedan inscriptos como pertenecientes a la realidad empírica y, como tales, sujetos a los juicios de valor racionales y obligatorios por parte del lector sino que éste puede admitir y de hecho, se le pide que acepte unos códigos que pueden distar mucho de su sistema axiológico sin ningún tipo de “consecuencia” perjudicial para sí pues queda todo en el juego literario. Como hemos visto, la modalidad de la primera persona para la narración es privilegio del relato fantástico y de géneros no literarios como la carta o el diario íntimo que, sin embargo, Ocampo emplea con fines estéticos. En sus manos, no sólo sirven un fin de autoconocimiento en la exploración de la identidad (de los personajes, del escritor, o bien del ser humano) sino también como recurso de enmascaramiento de la voz narrativa para crear la ilusión autobiográfica y experimentar con las formas de la narración (los cuentos-carta o los poemas-carta, por ejemplo). Sin embargo, el relato en primera persona también permite desenmascarar al narrador no confiable y facilitar la 
exposición de la ironía y la reconstrucción del relato por parte del lector, cuando se trata de ironía encubierta (covert irony en los términos de Booth).

“Hay bondades que matan” dice Régula/Piluca y con esa sentencia (variante, en realidad de "hay amores que matan”) que en el nivel textual parece referirse a la actitud de Artemia hacia ella, queda expuesta la culpa soterrada que siente. Pretende justificarse en su accionar que, en última instancia, la hace si no responsable, al menos cómplice de la muerte de Artemia, pues las vestiduras que surtieron el efecto deseado fueron las que ella le sugirió.

Artemia es el estereotipo de la mujer que se define a sí misma como objeto de deseo del hombre/sujeto. Hasta ahí no hay ningún elemento feminista en la concepción del personaje. Por el contrario, el posicionamiento ideológico que parece asumir el cuento sería el de la condena de la conducta femenina, la cual no se adecúa a la norma social establecida según los cánones de la sociedad patriarcal que asocia lo femenino con la pasividad y a lo masculino con la actividad.

Por otro lado, el cuento puede leerse desde una perspectiva feminista como el logro de la mujer que descubre y abraza su sensualidad. Para esta actitud, Segarra nos propone la siguiente explicación: “cuando la mujer deja de ser el objeto que refleja la imagen esperada por el sujeto masculino provoca desconcierto y resistencia”. (173) ${ }^{44}$

A pesar de rechazar la etiqueta de feminista, está claro que Ocampo realiza una crítica descarnada a la sociedad patriarcal desde la parodia, la sátira, el fantástico. Desde

\footnotetext{
${ }^{44}$ Marta Segarra y Angels Carabí en Feminismo y crítica literaria. Barcelona, Icaria. 2000. Citado en la tesina de Patricia Celedón (7).
} 
la temática de sus relatos hasta su quehacer autorial, Ocampo, en tanto mujer, se adentra en temas y ámbitos atípicos para las escritoras mujeres: el relato fantástico (narrativa antirrealista), por un lado, el erotismo y la articulación del deseo femenino, por el otro ${ }^{45}$.

Tal como lo define Molloy, el lenguaje de Ocampo es el de la exageración. Sus personajes llevan los sentimientos, las acciones, los conceptos hasta las últimas consecuencias: no andan en medias tintas. Así, el juego de opuestos que plantea desde la construcción de Artemia y Régula a partir del estereotipo logra un mayor efecto irónico al socavar la bondad de "la buena” (Régula) y atenuar la maldad de "la mala” (Artemia) hasta el punto de llevar al lector si no a simpatizar con Artemia, cuando menos a condenar la hipocresía de Régula y con ella criticar la moral pacata la de la sociedad burguesa.

\section{Al decorar el relato con elementos "sobrenaturales" o cuando menos}

"desconcertantes" (como el hecho de que el vestido haya sido copiado en lugares remotos) lo inscribe en el marco del fantástico lo cual le permite más libertad de acción. Así, su escritura planta un artefacto de corrosión masiva en el seno de la sociedad patriarcal y en el corazón de la burguesía pasando de la afirmación de la autodeterminación femenina a una actitud francamente subversiva. El plan de acción es muy sutil pero precisamente es lo que lo hace más eficaz.

\footnotetext{
${ }^{45}$ Queda hecha la salvedad acerca del tratamiento de estos temas en la narrativa corta. En la literatura argentina hay antecedentes en la poesía, por ejemplo, de Alfonsina Storni pero, sin desmedro de su significación desde el punto de vista de la escritura femenina, no constituye una anomalía (como Ocampo) pues entonces y por largo tiempo se concebía la poesía, en particular, la lírica, como un modo de expresión más acorde con la "sensibilidad femenina".
} 
Ocampo presenta dos personajes antagónicos, representantes cada una de una parte del binomio mujer buena/mujer mala. Esta vez es Ocampo quien recurre a la paradoja, cuando, como crítica o protesta en contra de los estereotipos intensifica hasta la ironía las conductas de los personajes, a tal punto que el lector termina simpatizando con la 'mujer mala' y tomando distancia de la `buena’. (Celedón 37)

Siguiendo el análisis de Celedón, queda claro que lo fantástico en el cuento "Las vestiduras peligrosas":

permite a la escritora ironizar acerca de la moral de la sociedad. Primero presenta el postulado de que la mujer en el espacio exterior corre peligro y que no se pueden transgredir las reglas sin recibir un castigo (Jackson 2001) y luego deja entrever, a través de su protagonista, que la mujer tiene derecho a ser lo quiere ser, aunque esto sea ser violada y asesinada. (37)

En Artemia se verifica una conducta diferente al modelo vigente y su manifestación del rechazo a la mediocridad de sus vidas y a la insatisfacción con el rol asignado a ellas por su entorno social. (Celedón 38) Esto también puede decirse de Cornelia, protagonista de "Cornelia frente al espejo".

A lo largo del análisis, hemos asistido a la construcción de la identidad de los personajes por medio de estereotipos y prescripciones y a la deconstrucción de los mismos para permitir la transgresión y subversión (Celedón 38). En otro sentido, el cuento tiene cierta afinidad con lo que Antonin Artaud propone en el teatro de la 
crueldad. Calafell Sala observa sobre el gesto de subversión de las mujeres de Ocampo lo siguiente: “Al salirse del papel que tradicionalmente les ha sido asignado es cuando se produce el desajuste que hace aparecer «un costado cruel o, más aún, decididamente perverso que sorprende y deja al lector sin aliento o en una especie de desconcierto pensante» ${ }^{46,} .(65)$

Es posible reconciliar el personaje de Artemia con una lectura feminista a partir de la noción de autodeterminación y agencialidad que adquiere el personaje frente a la expectativa de la ideología patriarcal que la relega a un rol pasivo. Artemia ejemplifica lo que Bataille describe como sujeto erótico. Su actividad erótica está destinada a su significación a pesar de que conlleve una conducta masoquista y la posibilidad de la muerte:

Podemos decir del erotismo que es la aprobación de la vida hasta en la muerte. ... [E]sta fórmula da mejor que ninguna otra el sentido del erotismo. ... [S]ólo los hombres han hecho de su actividad sexual una actividad erótica, donde la diferencia que separa al erotismo de la actividad sexual simple es una búsqueda psicológica independiente del fin natural dado en la reproducción y del cuidado que dar a los hijos. ... En efecto, aunque la actividad erótica sea antes que nada una exuberancia de la vida, el objeto de esta búsqueda psicológica, independiente como dije de la aspiración a reproducir la vida, no es extraño a la muerte misma. (8)

\footnotetext{
${ }^{46}$ La cita interna es de Reina Roffé, “Sabia locura” 18.
} 
Aunque Bataille no se refiera necesariamente al sujeto femenino, su rechazo de la noción de actividad sexual simple, es decir, de la destinada a la reproducción y el cuidado de los hijos, permite adjudicar la actividad erótica a la mujer también.

El punto más problemático acerca de esta concepción del personaje es su disposición de llevar esa actividad erótica hasta las últimas consecuencias y en particular, desde una expresión masoquista, a través de la violencia. En este sentido, Bataille afirma: "El terreno del erotismo es esencialmente el terreno de la violencia, de la violación.” (12)

Paradójicamente, los vestidos no visten sino desvisten el cuerpo, lo exhiben, en un acto de provocación que resulta infructuoso. La lógica del cuento desafía toda premisa: cuando más cubierta está, es cuando logra su cometido: la violación del cuerpo.

Ocampo hace un doble movimiento de afirmación del cuerpo, si bien, bajo el sistema axiológico convencional, podría percibirse como un valor negativo (violación y muerte). Parecería que entre las perspectivas en conflicto, la moral (Régula-Piluca) versus la disolución (Artemia), la primera es quien gana la partida. Sin embargo, la lectura feminista de la obra resulta más que subversiva y se torna una crítica por demás ácida y mordaz al sistema patriarcal: la violación guarda relación de causalidad con el trasvestismo que adopta el personaje, irónicamente, a sugerencia de Régula, en nombre de la moral. Ocampo exhibe así la doble moral de la sociedad patriarcal que, en primer lugar, le cierra el lugar a la mujer y, en segundo, cae presa del miedo que más trata de reprimir, el miedo a la castración, el impulso homoerótico, revés de su machismo. Descubierta la transgresión, que una mujer entre en ese espacio, se la castiga con la 
muerte "por tramposa". Es notable que la estrategia surta efecto en otros espacios (Budapest, Tokio, Oklahoma) pero no en Buenos Aires, lugar donde presumiblemente transcurre la acción. Se presenta así otro lanzazo de la crítica ocampeana a la cerrazón del ambiente porteño pequeño burgués.

Según la concepción de Bataille, la obra de Artemia de ocultar y exhibir el cuerpo es la forma de liberación y afirmación:

La acción decisiva es la de quitarse la ropa. La desnudez se opone al estado cerrado, es decir, al estado de la existencia discontinua. Es un estado de comunicación, que revela un ir en pos de una continuidad posible del ser, más allá del repliegue sobre sí. Los cuerpos se abren a la continuidad por esos conductos secretos que nos dan un sentimiento de obscenidad. La obscenidad significa la perturbación que altera el estado de los cuerpos que se supone conforme con la posesión de sí mismos, con la posesión de la individualidad, firme y duradera. (Bataille 13)

Ocampo afirma a través de la narración el reconocimiento del deseo sexual femenino y el derecho al placer erótico. El personaje concebido, sin embargo, parece ser una expresión invertida de la concepción de Bataille:

Toda la operación del erotismo tiene como fin alcanzar al ser en lo más íntimo, hasta el punto del desfallecimiento. El paso del estado normal al estado [13] deseo erótico supone en nosotros una disolución relativa del ser, tal como está constituido en el orden de la discontinuidad. Este 
término de disolución responde a la expresión corriente de vida disoluta, que se vincula con la actividad erótica. En el movimiento de disolución de los seres, al participante masculino le corresponde, en principio, un papel activo; la parte femenina es pasiva. Y es esencialmente la parte pasiva, femenina, la que es disuelta como ser constituido. Pero para un participante masculino la disolución de la parte pasiva sólo tiene un sentido: el de preparar una fusión en la que se mezclan dos seres que, en la situación extrema, llegan juntos al mismo punto de disolución. Toda la operación erótica tiene como principio una destrucción de la estructura de ser cerrado que es, en su estado normal, cada uno de los participantes del juego. (13-14)

A pesar de que el discurso de Bataille recrea los roles activo-pasivo de la normatividad patriarcal y puede resultar problemática para la apropiación feminista, Artemia trasciende esas limitaciones al lograr su cometido cuando se transviste.

Ocampo nuevamente subvierte las expectativas incluso las posibles objeciones feministas, al lograr que Artemia usurpe el espacio masculino cuando se viste de hombre, con lo cual también subiverte el discurso del erotismo asumiendo el rol activo hasta el punto de la destrucción. La muerte, entonces, se presenta como afirmación de la vida y de su voluntad. Jaque mate de Ocampo.

Considero interesante comparar la figura de Artemia con Janet, la protagonista de “Anillo de Moebius” de Cortázar. Se trata de un relato perturbador en el cual Janet, una maestra británica que se encontraba de paseo en bicicleta por la campiña francesa, es 
violada por Robert, un peón de campo e inadaptado social. Janet muere asfixiada durante la violación. Luego de ser enjuiciado y sentenciado, Robert se ahorca en su celda. En el más allá, Janet despierta a su sensualidad y deseo por Robert, pasando por un proceso de metamorfosis de una forma a otra en busca de un estado en el que pueda lograr la armonía y unión con el espíritu de Robert. Según observa Schmidt-Cruz en su análisis, la crítica se ha dividido en su valoración de la historia a raíz de su naturaleza polémica. De un lado, se considera perturbadora porque sugiere que la muchacha disfruta la violación o porque representa casi una apología de la violación (87). Muñoz, en cambio, la considera "Cortázar's restitution to women for his earlier sexist attitudes. Janet is possibly the only female pursuer in Cortázar's literature ... and through her Cortázar recognizes the woman's sexual desire and right to erotic pleasure.” (cit. en Schmidt-Cruz 88) Liberada por la muerte, la conciencia de la protagonista persigue al hombre, objeto de su deseo:

Muñoz concludes that at the end of the story "Janet es ahora parte activa en la formación de su propio destino: su deseo se convierte en acción, pero su propósito no es sólo liberarse de las lacras culturales que la han alienado del varón, sino también liberar al hombre de su machismo”. Sommer, while admitting that the construction of Janet's responses to rape is dubious if offensive, singles out "Anillo" as a representation of the striving toward utopian harmony due to its imagery of the Moebius strip that "breaks the earlier image of dichotomy between self and other" (cit. en Schmidt-Cruz 88). 
El fantástico se presenta como excusa para nombrar lo que no tiene nombre, la manifestación de lo siniestro, es decir, "la sensación inquietante que sigue a la manifestación de lo que debió permanecer secreto, oculto”. Mediante este recurso, Ocampo trata los temas más escabrosos. Así,

el lector participa de una construcción narrativa donde lo "normal” refiere a los sentimientos más característicamente secretos de la condición humana, todo aquello que la sociedad se ha esforzado desde hace siglos por restringir dentro del ámbito de lo que debe mantenerse reprimido, lo que es vergonzoso, censurable que se manifieste. Lo siniestro viene, justamente, del hecho de que la subversión del orden permite el funcionamiento de una lógica contrapuesta a la construcción axiológica social; en los relatos de Silvina Ocampo, el mundo narrado se rige por leyes incompatibles con la legalidad cotidiana (Murillo-Chinchilla, 66)

Esto explica el marco de agencialidad que Ocampo construye para el personaje y el distanciamiento que supone de lo real. Suárez Hernán, por su parte, apunta:

la magia y la fantasía son elementos de subversión femenina. Los temas fantásticos se desarrollan en un ámbito de marginalidad, en la liminalidad de lo establecido; por ello la feminidad y la infancia son espacios propicios para la deconstrucción de estereotipos y la creación de nuevos órdenes mediante recursos fantásticos. (370) 
En la medida de la distancia que medie entre el mundo narrado y el mundo de lo real, se percibirá en mayor grado la magnitud de la crítica que Ocampo realiza desde sus cuentos “crueles”. La supuesta crueldad no está en el autor, el narrador, el personaje, o el mundo narrado sino en la sociedad que indirectamente los alimenta. A propósito, Suárez Hernán afirma:

las mujeres y los niños se encuentran siempre cerca de los actos crueles; los personajes femeninos son perversos y capaces de asesinar. La violencia ejercida por mujeres genera la extrañeza, debido a la oposición a los paradigmas tradicionales de género en torno a la mujer pasiva, cooperativa y cuidadora. (371)

Así como algunas corrientes feministas se han apropiado de los epítetos denigrantes de la mujer para resignificarlos como afirmaciones de feminidad, en un movimiento similar Ocampo se apropia de los códigos anti-mujer, los subvierte y los resignifica. Esto no quiere decir que esté de acuerdo con una lectura de género de su obra, como bien lo dejó en claro en diversas declaraciones. Los procedimientos que utiliza son típicos de las tretas del débil, con la salvedad de que no hace bandera de ello. Esta estrategia, sin embargo, resulta más eficaz por lo sutil de modo que logra quebrar la norma por la estricta adhesión a ella.

Otro motivo que recorre el cuento es el de la creación artística como producto de la sublimación. Una lectura psicoanalítica abre la puerta para observar los mecanismos inherentes a la creación artística y ensoñación según aparecen representados en el relato. Artemia es creadora y replica con total firmeza: "Yo me eduqué a mí misma...” (36) 
Puede observarse una parodia incesante del paradigma patriarcal y del estereotipo femenino mediante la apropiación del discurso propio de los hombres y la ambivalencia de género en las voces narrativas. Son frecuentes las transformaciones de género y los relatos en los que las convenciones genéricosexuales deben operar como determinantes de sentido. La práctica del mal concede a las mujeres de los relatos ocampeanos gran protagonismo y supone una puesta en solfa de la oposición paradigmática de los sexos. Las mujeres de los cuentos distan mucho de la actitud pasiva e inofensiva reservada a las mujeres en la tradición literaria; por el contrario, los personajes femeninos de Ocampo llevan a cabo actos que tienen consecuencias y que dejan marcas profundas (Ostrov 1996).

Andrea Ostrov analiza la construcción del género en la obra de Ocampo y muestra un posible cuestionamiento de lo que significaría “escribir como una mujer”. Parece claro que el género es una categoría superpuesta al sexo como unconstructo social. Así, los textos plantean una cierta oposición a la postura esencialista del feminismo ofreciendo versiones de la feminidad muy diferentes.

Los cuentos de Ocampo muestran una concepción de la subjetividad genérica como construcción vinculada al artificio y a la confección (Ostrov 2004). La autora toma el pensamiento dicotómico que establece la diferencia sexual y establece los paradigmas de género para así deconstruirlos. (Suárez Hernán 371-72)

Según lo expone en su artículo “Amo y esclavo”, Mancini también ve en este cuento una representación de la dialéctica del amo y del esclavo y la política de la traición que desemboca en el crimen. Artemia, el ama, muere, no cuando viste sus 
diseños provocativos, sino la noche que sale vestida con traje de hombre por sugerencia de la criada. Se trata de noche en que se viste (se trasviste) por sugerencia de la criada, Régula-Piluca, la modista, con un traje de hombre supuestamente con el fin de protegerla (afloran otra vez los rasgos de homosexualidad). Según explica Mancini:

La ceremonia estaría presente en las salidas nocturnas que, como un ritual, el ama representa ataviada con las vestiduras que ella diseña y la criada «hace». Cada vez más provocativas y sensuales, las vestimentas subrayan la fatalidad de la ceremonia: encontrar el camino del goce perverso en la violación o la Muerte. Pero el ama muere precisamente el día en que, siguiendo los consejos de su criada, se viste de hombre con un traje diseñado y realizado por la criada. (86)

En cuanto a la formulación del juego de distancias y proximidades en torno a esta ceremonia, Mancini propone la siguiente configuración:

La mañana siguiente a cada salida ritual, la joven ama se entera de que, en otro lugar del planeta, una joven vestida con sus propios diseños es violada. Ella reniega de su propia suerte y acusa de copiona y traidora a ese doble. Cuando muere, la distancia se anula. Ambas mujeres son una sola Muerte con las vestiduras de la criada. (86)

Otra lectura que por contraste ilumina la recursividad de Ocampo con respecto al trasvestismo es la siguiente reseña de Balderston en la Encyclopedia of Latin American Writers: 
The saints' lives retold in Breve Santoral, similarly, are full of unresolved tensions. Santa Teodora, for instance, dresses as a man and becomes a monk, only to be accused falsely of fathering a child. Unwilling to defend herself against the unjust accusation, her saintliness is revealed only upon her death, when her body is being washed and her female nature is revealed. It is fitting that Ocampo’s book on religious poems (illustrated with Norah Borges's trademark angels) should reveal the story of a tranvestite saint. (593)

De todos los posibles referentes de Teodora, Ocampo elije Santa Teodora de Alejandría, la cual, incluso para la hagiografía católica representa un caso atípico. Es decir, la autora no elude las figuras ni las posturas más conflictivas en lo que respecta al género y la sexualidad, con el fin de afirmar la identidad femenina a partir de la diferencia y reclamar un lugar de igualdad, lejos de los discursos estridentes y los gestos ineficaces de ciertos sectores del feminismo de los que se distingue.

A modo de cierre, es necesario comentar sobre la ubicuidad del terciopelo como género de los “vestidos protagonistas” de los cuentos seleccionados para este capítulo. La coincidencia y reiteración de este material da pie para considerarlo un elemento central y simbólico en la narrativa de Ocampo, asociado casi exclusivamente al territorio femenino, entendido tanto en el sentido de cuerpo como espacio, de lo cual, serían éstos claros ejemplos. Si en “El vestido verde aceituna”, el paño lujoso tiene para la institutriz un carácter más aspiracional, en “El vestido de terciopelo” y “Las vestiduras peligrosas” aparece como atributos que expresan identidad de clase (motivo por el cual, la nueva rica, 
Cornelia Catalpina, encarga un vestido de este material "fuera de estación”; es el primer diseño de Artemia que se menciona, y con el cual parece una reina).

Por otro lado, una connotación que no puede soslayarse es la del simbolismo sexual que le atribuye la teoría psicoanalítica. Tanto en la Interpretación de los sueños, como se comentó a propósito de "El vestido de terciopelo”, como en "Fetichismo”, el terciopelo refiere a las crines pubis. Como acota Mancini:

la frecuente elección del terciopelo como género predilecto para el vestuario de los personajes de Ocampo surgiere la posibilidad de considerarlo como un elemento fetiche y junto con esta posibilidad aparece el componente erótico. Sigmund Freud afirma que la piel y el terciopelo como fetiches "reproducen la visión de la vellosidad púbica que hubo de ser seguida por la vista del anhelado falo femenino" (“Fetichismo”, $O C$, t. XXI, Buenos Aires, Santiago Rueda Editor, 1955, p. 242) [cit. en Mancini]. El comentario de la protagonista de "El vestido de terciopelo" señalando casi con impudicia su atracción y su rechazo por esta tela remite simultáneamente a ambos sentidos. (58)

Ese componente erótico no está ausente de los otros cuentos. "En el vestido verde aceituna” es la imagen que "envuelve” la palabra "pudor" en la nota de despido de Miss Hilton, que se asocia a su contrario, la conducta impúdica y exhibicionista de la institutriz; en "Las vestiduras peligrosas” el alto componente erótico está signado por el diseño de los vestidos que exhiben el cuerpo y por la finalidad: la posesión sexual. 
Otra posibilidad de enfoque, más positiva y no necesariamente relacionada con el aspecto patológico de la sexualidad según la teoría freudiana, es la que explica la preferencia del terciopelo como símbolo de la sexualidad femenina activa que se expresa libre de los tabúes de la moral burguesa y católica que no reconoce el derecho al placer sexual por parte de la mujer. Ocampo emplea en “El vestido de terciopelo” y “Las vestiduras peligrosas” una imagen similar construida a partir de un uso idiosincrático del idioma que llama la atención sobre sí para subrayar la importancia del concepto. Nótese la selección léxica: “Cuando terminé el vestido y se lo probó me ruboricé. La Artemia se complacía frente al espejo, viendo el movimiento de las manos pintadas sobre su cuerpo, que se transparentaba a través de la gasa.” (“Vestiduras”) La mirada de la narradora se focaliza en determinados gestos de Artemia que, inconscientemente, articulan su deseo homoerótico. En “El vestido de terciopelo” la escena se repite delante del espejo con una variante:

Durante unos instantes la señora descansó extenuada, sobre el sillón; luego se puso de pie para mirarse en el espejo. ¡El vestido era precioso y complicado! Un dragón bordado de lentejuelas negras, brillaba sobre el lado izquierdo de la bata. Casilda se arrodilló, mirándola en el espejo, y le redondeó el ruedo de la falda. Luego se puso de pie y comenzó a colocar alfileres en los dobleces de la bata, en el cuello, en las mangas. Yo tocaba el terciopelo: era áspero cuando pasaba la mano para un lado y suave cuando la pasaba para el otro. El contacto de la felpa hacía rechinar mis 
dientes. Los alfileres caían sobre el piso de madera y yo los recogía religiosamente uno por uno. ¡Qué risa! (énfasis mío)

La contemplación en el espejo se vuelve un simulacro de ceremonia. La belleza, lo intrincado del dragón lo hace brillar. Cornelia está fascinada. Casilda se arrodilla. La niña fija la mirada en los detalles del ritual. El vestido ejerce un poder de fascinación sobre todos los personajes, pero es en boca de la niña como se expresará la propiedad característica del terciopelo que luego repetirá Cornelia. La niña se concentra en la sensación disímil al tacto, lo cual le da risa. Cornelia expresa lo mismo, pero agrega lo ambivalente de su sensación: le agrada y le repugna a la vez. El paralelismo con la percepción de la sexualidad entre las dos edades, indiferenciado en la niñez y problemático en la experiencia destaca la carga simbólica de este elemento. 


\section{CONCLUSIÓN}

El estudio de la obra cuentística de Ocampo a través de los textos seleccionados apoya la observación preliminar que motivó esta investigación: la inestabilidad de los textos como característica dominante de la producción ocampeana. Ocampo innova en los temas y propone un desvío formal respecto a la tradición literaria argentina de su tiempo. Esa inestabilidad formal y libertad temática dan por resultado una obra que se resiste a la clasificación reduccionista y, en cambio pide un acercamiento multifacético. La inestabilidad del terreno narrativo es la primera impresión que recibe el lector al acercarse a los textos de Ocampo.

El habla popular, elemento innovador en la ficción rioplatense, es una de las estrategias desestabilizadoras ya que abre la puerta al cliché a partir del cual se enriquece la caracterización de los personajes y se vehiculiza la economía del relato, así como lo hace el estereotipo, los cuales dan paso a la ironía y el humor. La renovación del lenguaje, la predilección por el oxímoron, la inversión y la paradoja ponen a prueba los límites del sistema de significación y revelan sus falencias para luego explotarlas al máximo, configurando una marca de estilo propio.

$\mathrm{Al}$ abrir las compuertas al acervo lingüístico de la cultura popular que es marca de clase, Ocampo ensancha el espacio narrativo para albergar a personajes de la clase popular que no tenían voz ni representación en dicho espacio. Ocampo los invita a pasar, a no quedarse afuera. Una vez que pisan el escenario, que salen a escena, ya no hay vuelta atrás. Los invitados toman luego posesión de la casa y conviven con los dueños, o mejor dicho, los inquilinos originales, transformando el espacio de ahí en más en una 
sede del Carnaval ${ }^{47}$. Las ramificaciones de la inclusión del personaje popular (modistas, costureras, sirvientas, institutrices, maestras, adivinas, vendedoras, peones, etc.) dan cuenta de un uso que se aparta de la práctica tradicional de presentarlos como mero telón de fondo o recurso de color local para darles el papel protagónico que define no sólo su estilo sino una corriente posterior en la narrativa argentina.

Además de los personajes populares hay que destacar el lugar de privilegio que también concede a los niños, los viejos, las mujeres, una especie de grupo de desplazados de lo que se considera tradicionalmente materia literaria. La inclusión de estos personajes de la mano de los temas que inspiran arroja una luz distinta sobre el mundo cotidiano. Una vez que alza vuelo en las alas de la imaginación, no le es difícil aplicar el mismo procedimiento a los materiales narrativos para abrir nuevo modo de representación literaria a partir de la originalidad en los temas y el desenfado con el que los aborda. En los primeros cuentos aparecían los recursos formales que definían un modo de representación emergente en el sistema literario argentino. Recién en 1960, se percibe por primera vez, una mayora estilización del lenguaje en la escritura de Ocampo.

La primera estrategia ocampeana es la de desfamiliarizar el referente empírico del lector a través de lo fantástico, que irrumpe desde un lenguaje marcado por el uso irreverente de la sintaxis y los recursos estilísticos. La ambigüedad del enunciado y la

\footnotetext{
${ }^{47}$ El motivo del carnaval recorre la obra de Ocampo. Bajtín define el Carnaval como un fenómeno por esencia polifónico: la percepción carnavalesca del mundo posee un extraordinario poder de regeneración y de transfiguración, una vitalidad inagotable. El carnaval elabora todo un lenguaje de formas simbólicas y concretas desde las grandes y complejas acciones de las masas. Este conjunto de ritos y festejos que tienen profundas raíces sociales, es un fenómeno interesante en la historia de la cultura, en la medida que se refleja en lo literario, pues permite ver cómo se establece una vez más la relación literatura-sociedad. De alguna manera, la carnavalización es el producto del diálogo del creador y la cultura popular pues el texto se sitúa en la historia y en la sociedad.
} 
ambigüedad de situación se construyen a partir de una enunciación que se apoya en la literarlidad de los juegos de palabras, el oxímoron y la paradoja. Del oxímoron del enunciado no basta más que un salto para la instalación de la paradoja en del universo narrativo. La sensación de extrañeza invade al lector que percibe los dos planos de referencia como simultáneos. Sus cuentos constituyen una expresión singular dentro del fantástico, pues los acontecimientos desfamiliarizantes pueden entrar en la más banal de las situaciones. Cuanto más simple parece la historia, mayor es el riesgo: la posibilidad de una catástrofe yace escondida y el lector la intuye y la espera.

Si existe valor alguno en el hecho de comparar a Ocampo con otros autores de la época, se trata sólo de un valor meramente referencial. A diferencia de otros de sus contemporáneos, Ocampo supo perfeccionar su estilo sin renegar de sus primeros cuentos publicados. Los aciertos de Viaje olvidado en materia de originalidad superan con creces los defectos gramaticales de redacción que tanto molestaron a Victoria Ocampo. Los vuelos de la imaginación y la experimentación formal que inaugura ese volumen encuentran su plenitud en los dos últimos contarios. Tal como lo atestiguan el estudio de Tomassini como los ensayos de Ulla, las coordenadas de Viaje olvidado se retoman con mayor destreza en los dos últimos volúmenes que demuestran la consolidación del estilo ocampeano y la renovación que aporta a la concepción genérica del cuento.

Si bien coincido con Valenti en que Autobiografía abre nuevos horizontes en el cuento, abro un paréntesis en lo que significa este volumen en la trayectoria de Ocampo pues se trata del volumen de filiación más “borgeana” en cuanto al trabajo de construcción de tramas minuciosamente más perfectas, en claro 
despegue del carácter más experimental y renovador de Viaje olvidado, el cual no fue comprendido por la crítica del momento y atribuyeron algunos de sus rasgos distintivos a descuido o falta de rigor en la ejecución. Ulla insiste una y otra vez en la filiación borgeana de Autobiografia de Irene que pone de relieve el cambio de rumbo que se opera con los siguientes volúmenes: La furia y otros cuentos y Las invitadas. Comparto la observación de Tomassini y Ulla de que el germen de la renovación de las formas ya se enconraba en Viaje olvidado.

El caso de Ocampo podría compararse al de Dalí. Es conocido el hecho de que Dalí no recibió el grado de la academia de pintura española por diferencia de criterios artísticos que se apartaban de su determinación e impronta artísticas no sin antes haber demostrado que su voluntad de ruptura con los cánones estéticos eran independientes de su maestría en el manejo de las técnicas clásicas más logradas. En este sentido, Ocampo parece haber buscado dejar asentada su maestría técnica para acallar a la crítica y poder dedicarse con total libertad a las líneas estéticas que se planteó desde el momento en que sintió esa urgencia y esa necesidad de escribir, como vehículo de expresión artística más apto que la pintura y más apto que la música.

Las estrategias desestabilizadoras alcanzan a las formas y las reglas de composición de los cuentos, la cual sigue una evolución en el transcurso del tiempo y queda reflejada en ellos. Resulta claro que, a medida que su obra madura, exhibe una mayor audacia en los temas y una mayor flexibilidad en las formas a partir de un juego fluido de las normas genéricas. Como observé oportunamente, una de las obras que 
ejemplifica esta cualidad es “Cornelia frente al espejo” que incorpora la fuerza del diálogo que es el elemento central del teatro con fragmentos narrativos dispuestos en juego de cajas chinas para articular las evocaciones del recuerdo, y con los fragmentos enciclopédicos que constituyen digresiones eruditas.

Rosemary Jackson subtitula su estudio de género, Fantasy, con “The Literature of Subversion”. Ése es precisamente el planteamiento estético y literario de Silvina Ocampo: una literatura de la subversión a través del fantástico. Utilizo el término “fantástico" en un sentido amplio que comprende la noción de género y de modalidad. A través del fantástico, en tanto embestida al realismo, Ocampo logra acceder a los temas más escabrosos y convertir los hechos más comunes en materia literaria creando un espacio propio que se distingue de la producción literaria precedente, contemporánea y posterior por su ruptura de las formas, por su desdén de las normas del "buen gusto” (si es que existe) y de los cánones literarios. De allí que su obra desconcierte, desestabilice, tanto a la crítica como al lector: reacción prevalente que se verifica en toda aproximación a su obra. Sin embargo, así como desconcierta y desestabiliza, también atrae, deslumbra y cautiva, a partir de la combinación magistral de elementos antitéticos, actualizando en el plano de la comunicación lo que sus versos anuncian: “con la belleza y el horror por guías”. Quizás el rasgo más notable en el estilo de Ocampo es haber sabido encontrar materia poética y belleza en los lugares más insospechados: así, al reconocer la belleza en el horror, en lo abyecto, en lo marginal, pone en jaque nuevamente al lector. Al dar a esos elementos visibilidad literaria realiza un rescate que obliga al lector a repensar sus impresiones y transformarlas. 
Por su voluntad iconoclasta, su búsqueda de la belleza resulta en una modalidad expresiva que rompe las normas del "buen gusto literario" que impera en el ámbito de la literatura rioplatense de la época, siempre mirando a las formas clásicas a la mesura de los temas y la medida en la expresión cuidada como sus más altos valores. Por eso su voluntad renovadora no encuentra eco en un público que no está preparado todavía para recibirla. Puede decirse que Ocampo es una escritora postmoderna avant la lettre, que refleja en sus obras un nuevo lenguaje, el del habla popular, que antes estaba tácitamente prohibido de lo que podía llamarse literatura. Si bien en su originalidad no tiene antecedentes o sucesores, comparte con otros autores "únicos” o innovadores la distinción de ser objeto de culto y de rescate por generaciones posteriores, como es el caso de Felisberto Hernández, con quien coincide, además en ser exponente del cuento fantástico, o la preferencia por la modalidad narrativa de la primera persona. Por otro lado, coincide con otros escritores contemporáneos en que vivió una identidad más europea que tercermundista como se categorizaba entonces a América Latina, con los ojos y el corazón puestos en Francia como cuna y fuente de las letras, y “a home away from home”.

Ocampo se adelanta a Cortázar en el estilo de los cuentos-carta. Se distingue de Cortázar por la ausencia de un planteamiento ideológico. Sin embargo, este punto es debatible, pues el hecho de que no adopte una postura pública frente a diversos asuntos del ámbito geopolítico mundial o que su literatura responda al devenir de la historia su alejamiento del ojo público le concede libertad de acción para perseguir sus gustos estéticos y originalidad en su consecución. Por supuesto, el precio de la libertad y la 
originalidad a veces puede ser, como en el caso de Ocampo, el de la soledad. El poco reconocimiento que tuvo su obra en vida de la autora está comenzando a remediarse póstumamente. Su obra tiene plena vigencia a veinte años de su muerte. Continúa siendo objeto de estudio y descubrimiento tanto para la crítica como para el público en general.

Ocampo se desliga de las anclas generacionales y, como los clásicos, continúa produciendo sentidos aunque, al mejor estilo desconstruccionista, el significado siempre quede diferido. La fantasía y la sátira informan el mundo de los cuentos ocampeanos que son más perversos y quizás más "surreales” en el sentido de "inexplicables”. En sus cuentos subyace la noción de que ser humano es ser absurdo.

No cabe duda de que el proceso creativo, la necesidad de encontrar un vehículo de expresión adecuado a la vena artística fue siempre una preocupación de Ocampo, una fuente de meditación, y que se refleja en la materia que constituye los cuentos, entre ellos, los que se estudian aquí:

Así me empecé a desilusionar. Me alejé de una pasión que también me resultaba una tortura. ¿Qué me quedaba? ¿Escribir? ¿Escribir? Estaba la música, pero tan lejana de mí como la luna. Hacía mucho tiempo que escribía y escondía lo que había escrito. Tanto que se hizo en mí una costumbre el escribir y esconder: como si Dios me pudiera aliviar y darme una buena noticia, que nunca llegaba. El mundo no es mágico. Lo hacemos mágico, de pronto, dentro de nosotros, y nadie se da cuenta, hasta que pasan muchos años. Pero yo no esperaba ser reconocida: me parecía la cosa más horrible del mundo. Nunca sabré qué fue lo que esperaba. Un 
mendigo que duerme bajo un árbol sin nada en el mundo que lo proteja es más feliz que un hombre famoso, alguien reconocido por su encanto o talento. ¿Es que siempre seremos estudiosos de nosotros mismos? $?^{48}$

Las estrategias desestabilizadoras se basan en el anclaje que proporciona la teoría de la recepción. Al poner en jaque el horizonte de expectativas del lector en manera constante en todos los niveles, bien se dice de Ocampo que parece operar dentro de la tradición de la visionaria cuya sensibilidad cruza múltiples fronteras. Por un lado, ejecuta la ruptura, inversión o renovación de los elementos constitutivos del cuento como género narrativo, reduciendo, en algunos casos los elementos al mínimo, como puede verse en su primer volumen, Viaje olvidado y en su obra de madurez, representada por $Y$ así sucesivamente y Cornelia frente al espejo donde esa desnudez de las formas, la economía de la composición remite al primero pero evidencia la evolución del estilo y de la voz propios, inconfundible en su identidad pero más logrado. Por otro lado, hace gala de un perfecto dominio de la técnica poniendo en exhibición las construcciones más elaboradas, con tramas perfectas de mecanismo de relojería de lo cual el volumen Autobiografía de Irene da testimonio. Al demostrar Ocampo que escribe y lo hace bien deja atrás el escollo que supone la crítica certera que supone la reseña de Victoria Ocampo sobre Viaje olvidado y queda en plena libertad para perseguir los vuelos de la imaginación y la renovación según sus preferencias, obsesiones y sensibilidades estéticas.

\footnotetext{
48 Silvina Ocampo “¿Qué quedará de nosotros?” traducción al español del escrito que, bajo el título "Introduction by the autor” abre la antología de cuentos traducidos al inglés por Daniel Balderston titulada Leopoldina s Dream. La traducción es de Marcos Montes, para el “Dossier Silvina Ocampo” colección de artículos coordinada por Reina Roffé para el número 622 de Cuadernos Hispanoamericanos en 2002.
} 
“Lo que importa es lo que escribimos: eso es lo que somos, no un muñequito inventado por los que hablan y nos encierran en una cárcel tan distinta de lo que habíamos soñado.” Desechando todo intento de encasillamiento, de petrificación por parte de la crítica o su entorno literario, Ocampo tiene a su favor la seguridad y la confianza que le aportan los años de continua y ardua labor literaria que arrojaron un sinnúmero de páginas publicadas y otro tanto o más inéditas, sin olvidar que la narrativa es sólo una parte de su obra pues con la misma entrega se dedicó a la poesía, la traducción, al teatro o a la crítica literaria.

Queda todavía mucha tela para cortar en el universo literario ocampeano enriquecido por el caudal de obras inéditas que están saliendo a la luz póstumamente. Entre ellas cabe mencionar la novela para chicos La torre sin fin, la novela La promesa, la colección de epígrafes y escritos variados Ejércitos de la oscuridad y el poema autobiográfico o la autobiografía en verso Invenciones del recuerdo. Si bien los límites de este trabajo no dan lugar a un comentario en profundidad de su obra póstuma, vale acotar que los hallazgos no hacen sino confirmar y reforzar las apreciaciones sobre la originalidad y la renovación que aporta Ocampo al cuento y a la literatura femenina de la postmodernidad.

Otro ámbito que pide un estudio detallado es el análisis comparativo de los cuentos infantiles (“El cofre volante”, “La liebre dorada”, “La naranja maravillosa”, “El caballo alado”, “El tobogán” y “Canto escolar”, entre otros) en lo que respecta a sus fuentes para exponer los mecanismos de composición y refundición bajo los cuales operan. Algunos críticos han señalado la necesidad de asumir este estudio y se han visto 
algunas respuestas en cuanto temas puntuales en relación con los cuentos "La liebre dorada” y “La soga”. Sin embargo, falta abordar un estudio sistemático y abarcador del corpus de la literatura infantil ocampeana y su relación con la de otros autores y el género en particular.

Otro ámbito de la obra de Ocampo que merece un estudio dedicado es el de las obras de teatro, tanto las propias como la que escribió en colaboración con Juan Rodolfo Wilcok, Los traidores. En el espacio de este estudio sólo he podido comentar brevemente El espejo ardiente por constituir uno de los términos del doble literario junto con el cuento “Cornelia frente al espejo” (analizado en el capítulo 3). Queda por emprender un estudio de la relación intertextual y la reformulación de los elementos que cada obra evidencia, desde la variante en la trama, hasta el nuevo enfoque del tema y el tratamiento de los personajes. De La lluvia de fuego no se ha publicado el texto original sino la traducción al francés La pluie de feu, siendo esta última la que fue llevada a escena en Francia. Las peripecias del manuscrito original agregan una nota de color muy ocampeana a esta producción. Sin desmedro de la calidad de la traducción, el acceso al original deviene un imperativo para encarar su estudio independiente, por un lado, y un trabajo de relevamiento de la labor de traducción, por el otro. Tampoco se ha editado la obra de teatro infantil No sólo el perro es mágico, que fue estrenada en 1958.

A lo largo de este estudio y en el transcurso de la tarea de investigación, he podido comprobar que la autora que se escapa del ojo público, que resiste la tentación de dar los pronunciamientos críticos del intelectual, es en el fondo un ser que prefiere la intimidad a la sociabilidad: "No soy sociable, soy íntima” dijo alguna vez. Si la obra 
artística es comparable a una construcción, en vez de los edificios monumentales construidos a fuerza de verbosidad que no busca otro fin que impresionar a los invitados con el despliegue de su riqueza y ornamentación, Ocampo elige esperar al lector a tomar el té en el espacio íntimo de alguna “casa de azúcar” construida con los elementos esenciales, mínimos, precisos, eclécticos, que le imprimen un carácter propio y original, que permite hablar de tú a tú y donde no faltan sus obras de arte predilectas o un piano de fondo. Por eso, para concluir, considero esencial dejar paso a las palabras de la autora acerca de los motivos que la llevaron a escribir, cuando ya había emprendido otras expresiones artísticas como la música o la pintura. Ocampo señaló oportunamente:

Escribí durante mucho tiempo sin que se enteraran de que yo escribía, algo totalmente informal, libre, ni verso ni prosa, me parecía que no era apto para ser leído o mostrado, hasta que un buen día empecé a leérselo a alguien. Cuando me di cuenta de que conmovía, me lancé a una especie de dedicación; en lugar de ponerme a dibujar me ponía a escribir, pero no había un lenguaje para eso... (sp)

En estas palabras de la autora se encuentra quizás la condensación de su obra y de su lugar como escritora: la búsqueda de un lenguaje propio y creador que satisfaga su ansia de expresión y comun(icac)ión con el lector. Sus cuentos, desde el punto de vista tanto temático como estructural, demuestran que el lector está presente en el proceso de composición y que tiene un papel relevante en la toma de decisiones que determinarán la configuración del objeto estético. Cada trama que teje la autora establece un vínculo con el fin de "perturbar, inquietar, alterar, mover fuertemente o con eficacia" al lector, ya que 
son precisamente ésos, los sentidos y matices comprendidos en el lema "conmover”, la causa y efecto de la narrativa de Silvina Ocampo. 


\section{REFERENCIAS}

Agosín, Marjorie. "Mujer, espacio e imaginación en LatinoAmérica: Dos cuentos de María Luisa Bombal y Silvina Ocampo.” Revista Interamericana de Bibliografia/Inter-American Review of Bibliography 41:4 (1991): 627-33. Impreso.

Aguirre, Osvaldo. "Tomándoselo muy a pecho". Radar Libros. Página 12. 10 de sep. 2006. (sp) En línea. http://www.pagina12.com.ar/diario/suplementos/libros/152234-2006-09-12.html. Acceso: octubre 2007.

Aldarondo, Hiram. "Barbarrossa enfrenta a Barbazul: Debate paródico entre Charles Perrault, Silvina Ocampo y Luisa Valenzuela.” Bulletin of Spanish Studies: Hispanic Studies and Researches on Spain, Portugal, and Latin America 80:6 (2003 Nov): 729-42. Impreso.

- - -. "Embestida a la burgesía: Humor, parodia y sátira en los últimos relatos de Silvina Ocampo.” Revista Iberoamericana 68:201 (2002 Oct-Dec): 969-79. Impreso.

- - -. Violación risible de la norma: La estética de la crueldad en la cuentística de Silvina Ocampo. Dissertation Abstracts International, Section A: The Humanities and Social Sciences 59:5 (1998 Nov), 1592. (Dissertation abstract)

Aponte, Barbara B. “The Initiation Archetype in Arguedas, Roa Bastos and Ocampo.” Latin American Literary Review 11:21 (1982 Fall-Winter): 45-55. Impreso.

Araújo, Helena. “Erotismo y perversión en un cuento de Silvina Ocampo.” Río de la Plata: Culturas 1 (1985): 141-145. Impreso.

- - -. "Ejemplos de la 'niña impura' en Silvina Ocampo y Alba Lucía Angel.” Hispamerica: Revista de Literatura 13:38 (1984 Aug.): 27-35. Impreso.

Astutti, Adrianna. Andares clancos: Fábulas del menor en Osvaldo Lamborghini, J. C. Onetti, Rubén Darío, J. L. Borges, Silvina Ocampo y Manuel Puig. Rosario: Viterbo, 2001. Impreso.

Bach, Caleb y Lisl Steiner. “The Inventions of Adolfo Bioy Casares.” Americas 45:6 (1993 Nov-Dec): 14-19. Impreso.

Bakhtin, Mikhail. The Dialogic Imagination: Four Essays. Austin: U of Texas P, 1981. Impreso.

Balderston, Daniel. “De la Antología de la literatura fantástica y sus alrededores”. Historia crítica de la literatura argentina. Buenos Aires: Emecé, 2004. 217-27. Impreso. 
- - -. "Los cuentos crueles de Silvina Ocampo y Juan Rodolfo Wilcock.” Revista Iberoamericana, 49:125 (1983 Oct.-Dec.): 743-752. Impreso.

- - -. “Silvina Ocampo (1903?-1993)” Encyclopedia of Latin American Literature Chicago: Fitzroy Dearborn, 1997 (593-594). Impreso.

Baron Supervielle, Odile. “Silvina Ocampo responde a Proust.” Suplemento Literario La Nación (Buenos Aires), (1994 Jan 9), p. 3. Impreso.

Barthes, Roland. El Grado Cero De La Escritura: Seguido De Nuevos Ensayos Críticos. Buenos Aires, Argentina: Siglo XXI Argentina Editores, 1973. Impreso.

Barthes, Roland y Stephen Heath. Image, Music, Text. New York: Hill and Wang, 1977. Impreso.

Barthes, Roland y Susan Sontag. Ensayos Críticos. Barcelona: Seix Barral, 1983. Impreso.

Bataille, Georges. El erotismo. Barcelona: Tusquets, 1985. Impreso.

Beccacece, Hugo. “Los Bioy: La guardiana de los secretos.” Suplemento Cultura La Nación (Buenos Aires), (2002 June 23): 1-2. Impreso.

Belsey, Catherine y Jane Moore, eds. The Feminist Reader: Essays in Gender and the Politics of Literary Criticism. Basingstoke: Macmillan, 1989. Impreso.

Bermúdez-Arceo, Viviana. "Las venganzas de la infancia." II Coloquio Internacional de Literatura Comparada: 'El cuento, ' I-II. Ed. Martha Vanbiesem de Burbridge. Buenos Aires: Fundación María Teresa Maiorana, 1995. II: 283-87. Impreso.

Booth, Wayne C. A Rhetoric of Irony. Chicago: University of Chicago Press, 1974. Impreso.

- - -. The rhetoric of fiction. Chicago: University of Chicago Press, 1961. Impreso.

Borges, Jorge Luis et al. “Recordando a Güiraldes.” Suplemento Literario La Nación (Buenos Aires), (1986 Feb. 9), p. 2. Impreso.

Borinsky, Alicia. "Ficciones de intimidad.” Utopías, ojos azules, bocas suicidas: La narrativa de Alina Diaconú. Ed. Ester Gimbernat González. Buenos Aires: Fraterna, 1993. 85-91. Impreso.

Bradford, Lisa Rose. "La visión de las versiones: Un estudio de diferencias/resistencias en Emily Dickinson.” Celehis: Revista del Centro de Letras Hispanoamericanas, 4:4-5 (1995): 117-32. Impreso. 
Camayd-Freixas, Erik. Realismo mágico y primitivismo. Lanham: UP of America, 1998. Impreso.

Celedón, Patricia. Tesina. "Silvina Ocampo - María Luisa Bombal: Dos íconos de la literatura fantástica latinoamericana Análisis de cuatro cuentos desde una perspectiva feminista” Göteborgs Universitet, 2007. En línea. https:/gupea.ub.gu.se/bitstream/2077/19541/1/gupea_2077_19541_1.pdf Fecha de acceso: octubre 2014.

Cerda, Martha. "El secreto como fuente de poder en la literatura femenina." Texto Crítico, 5:10 (2002 Jan-June), pp. 255-61. Impreso.

Cirlot, Juan Eduardo. Diccionario de símbolos. Barcelona: Siruela, 2004. Impreso.

Clark, Marcia B. "Feminization as an Experience of Limits: Shifting Gender Roles in the Fantastic Narrative of Silvina Ocampo and Cristina Peri Rossi.” Inti: Revista de Literatura Hispánica, 40-41 (1994 Fall-1995 Spring): 249-68. Impreso.

Clark, Maria Brigitta. The Feminine Fantastic in Short Fiction from the River-Plate. Dissertation Abstracts International, 54:3 (1993 Sept), 943A-44A. (Dissertation abstract). Impreso.

Díaz de León, Aída. From Disappearing Narrators to Signs of the Author: Images of the Subject in the Short Stories of Silvina Ocampo. Dissertation Abstracts International, Section A: The Humanities and Social Sciences, 64:2 (2003 Aug), 515. (Dissertation abstract) Impreso.

Duncan, Cynthia. "An Eye for an 'I': Women Writers and the Fantastic as a Challenge to Patriarchal Authority.” Inti: Revista de Literatura Hispánica, 40-41 (1994 Fall1995 Spring): 233-46. Impreso.

- - -. "Double or Nothing? The Fantastic Element in Silvina Ocampo's 'La casa de azúcar'.” Chasqui: Revista de Literatura Latinoamericana, 20:2 (1991 Nov): 6472. Impreso.

Ezquerro, Milagros. “Barba Azul en el jardín de invierno.” Cuadernos Hispanoamericanos, 622 (2002 Apr): 39-47. Impreso.

Ferreira-Pinto, Cristina. "El narrador intimista de Silvina Ocampo: 'La continuación'., Revista de Estudios Hispánicos, 17-18 (1990-1991): 309-15. Impreso.

Francomano, Emily. "Escaping by a Hair: Silvina Ocampo Rereads, Rewrites, and ReMembers 'Porphyria's Lover'.” Letras Femeninas, 25:1-2 (1999 Spring-Fall): 6577. Impreso. 
Freud, Sigmund, Joan Riviere, and James Strachey. Collected Papers: Authorized Translation Under the Supervision of Joan Riviere. New York: Basic Books, 1959. Impreso.

Freud, Sigmund. A General Introduction to Psycho-Analysis. New York: Simon and Schuster, 1963. Impreso.

Galán, Ana Silvia. “Las vestiduras peligrosas.” Cuadernos Hispanoamericanos, 622 (2002 Apr): 55-63. Impreso.

Genette, Gérard. Narrative Discourse: An Essay in Method. Ithaca, N.Y: Cornell UP, 1980. Impreso.

Genette, Gérard, and Jane E. Lewin. Narrative Discourse Revisited. Ithaca, N.Y: Cornell UP, 1988. Impreso.

Gilbert, Sandra M, and Susan Gubar. The Madwoman in the Attic: The Woman Writer and the Nineteenth-Century Literary Imagination. New Haven: Yale UP, 1979. Impreso.

Goodwin, Sarah M. K. W, and Elisabeth Bronfen. Death and Representation. Baltimore: Johns Hopkins UP, 1993. Impreso.

Grondona, Adela. “Silvina Ocampo”. Por qué escribimos. Buenos Aires: Emecé, 1969. (175-179). Impreso.

Hernández, Juan José. "La obra de teatro que escribimos con Silvina Ocampo.” Suplemento Cultura La Nación (Buenos Aires), (1999 Oct 24): 1-3. Impreso.

Homer, Sean. Jacques Lacan. London: Routledge, 2005. Impreso.

Hutcheon, Linda. A Theory of Parody: The Teachings of Twentieth-Century Art Forms. New York: Methuen, 1985. Impreso.

Iser, Wolfgang. The Act of Reading: A Theory of Aesthetic Response. Baltimore: Johns Hopkins UP, 1978. Impreso.

Klingenberg, Patricia N. Fantasies of the Feminine: The Short Stories of Silvina Ocampo. Lewisburg: Bucknell UP, 1999. Impreso.

- - -. "Silvina Ocampo frente al espejo.” Inti: Revista de Literatura Hispánica, 40-41 (1994 Fall-1995 Spring): 271-86. Impreso. 
- - -. "Divining the Self: Mirrors in Silvina Ocampo's Cornelia frente al espejo.” $L A$ CHISPA '93: Selected Proceedings. Ed. Gilbert Paolini. New Orleans: Tulane UP, 1993. 127-33. Impreso.

- - -. “The Feminine 'I': Silvina Ocampo's Fantasies of the Subject.” RLA: Romance Languages Annual 1 (1989): 488-494. Impreso.

- - -. “A Life in Letters: Notes Toward a Biography of Silvina Ocampo”. Hispanófila 139 (2003): 111-132. Impreso.

- - -. "The Mad Double in the Stories of Silvina Ocampo.” Latin American Literary Review 16:32 (1988 July-Dec.): 29-40. Impreso.

- - -. “The Twisted Mirror: The Fantastic Stories of Silvina Ocampo.” Letras Femeninas 13:1-2 (1987 Spring-Autumn): 67-78. Impreso.

- - - "A Portrait of the Writer as Artist: Silvina Ocampo.” Perspectives on Contemporary Literature 13 (1987): 58-64. Impreso.

Lacan, Jacques. Speech and Language in Psychoanalysis. Baltimore: Johns Hopkins UP, 1981. Impreso.

Lacan, Jacques, Héloïse Fink, and Bruce Fink. Ecrits: The First Complete Edition in English. New York: W.W. Norton \& Co, 2006. Impreso.

Lavou, Victorien. “Furias negras, chronique d'une ellipse.” Les Noirs et le discours identitaire latino-américain. Ed. Michèle Soriano. Perpignan: Centre de Recherches Ibériques et Latino-Américaines, Université de Perpignan (CRILAUP), 1997. 91-110. Impreso.

Lockert, Lucía Fox. “Silvina Ocampo's Fantastic Short Stories.” Monographic Review, 4 (1988): 221-229. Impreso.

López-Luaces, Marta. Ese extraño territorio: La representación de la infancia en tres escritoras latinoamericanas. Santiago: Cuarto Propio, 2001. Impreso.

- - -. Ese extraño territorio: La representación de la infancia en 'Cuadernos de infancia' de Norah Lange, 'Las invitadas,' 'Las noches de los dias' y 'La furia' de Silvina Ocampo y 'La semana de colores' de Elena Garro. Dissertation Abstracts International, Section A: The Humanities and Social Sciences, 60:2 (1999 Aug), 442-43. (Dissertation abstract). Impreso.

López-Luaces, Marta and Lea Fletcher. That Strange Territory: The Representation of Childhood in Texts of Three Latin American Women Writers. Estudios de Literatura Latinoamericana. 6. Newark: Cuesta, 2004. Impreso. 
Louis, Annick. "Definiendo un género. La antología de la literatura fantástica de Silvina Ocampo, Adolfo Bioy Casares y Jorge Luis Borges.” Nueva Revista de Filología Hispánica, 49:2 (2001): 409-37. Impreso.

Mackintosh, Fiona J. Childhood in the Works of Silvina Ocampo and Alejandra Pizarnik. Woodbridge, Suffolk, UK: Támesis, 2003. Impreso.

- - -. “"My Dreams Are of a Field Afar’ or Sonnets from the English: Silvina Ocampo's Relationship to British Poetry.” Symbiosis: A Journal of Anglo-American Literary Relations, 8:1 (2004 Apr): 91-107. Impreso.

Mackintosh, Fiona J. and Roberta Quance. "Speaking/Seeing Saints: Norah Borges and Silvina Ocampo Collaborate.” Romance Studies, 22:2 (2004 July): 149-63. Impreso.

Mancini, Adriana. “Amo y esclavo: Una relación eficaz: Silvina Ocampo y Jean Genet.” Cuadernos Hispanoamericanos, 575 (1998 May): 73-86. Impreso.

- -. Silvina Ocampo: Escalas de pasión. Buenos Aires: Norma, 2003. Impreso.

Mangin, Annick. “'El castigo’, de Silvina Ocampo: Parole et châtiment.” Cahiers du Monde Hispanique et Luso-Bresilien/Caravelle, 66 (1996): 113-20. Impreso.

- - -. “'El castigo’ de Silvina Ocampo: Parole et pouvoir.” Co-Textes, 33 (1997): 81-90. Impreso.

- - -. Temps et écriture dans l'oeuvre narrative de Silvina Ocampo. Toulouse: PU du Mirail, 1996. Impreso.

Mansau, Andrée. “Silvina Ocampo, du vert paradis à la pluie de feu.” L'Esprit et les Lettres. Ed. François-Charles Gaudard. Toulouse: PU du Mirail, 1999. 321-27. Impreso.

Mathieu, Corina S. "La subversión del orden en La furia y otros cuentos de Silvina Ocampo.” Alba de América: Revista Literaria, 11:20-21 (1993 July): 263-71. Impreso.

Menton, Seymour. El Cuento Hispanoamericano: Antología Crítico-Histórica. México: Fondo de Cultura Económica, 1986. Impreso.

Molloy, Sylvia. “La exageración como lenguaje”. Ficciones argentinas: Antología de lecturas críticas. Buenos Aires: Norma, 2004. 163-75. Impreso.

- - -. "Simplicidad inquietante en los relatos de Silvina Ocampo.” Lexis: Revista de Lingüística y Literatura, 2 (1978): 241-51. Impreso. 
Monteleone, Jorge. "La máscara sigilosa de Silvina Ocampo.” Suplemento Cultura La Nación (Buenos Aires), (2002 Oct 6): 1-2. Impreso.

Morello, Lilian and Annick Mangin. "El vestido de terciopelo/La Robe de velours.” Cinémas d'Amérique Latine, 12 (2004): 178-85. Impreso.

Noullez, Lucien. “Silvina désespérée." Courrier du Centre International d'Études Poétiques, 221 (1999 Jan-Mar): 23-29. Impreso.

Ocampo, Silvina. Cuentos completos I. Buenos Aires: Emecé, 1999. Impreso.

- - -. Cuentos completos II. Buenos Aires: Emecé, 1999. Impreso.

- - -. Páginas de Silvina Ocampo. Buenos Aires: Celtia, 1984. Impreso.

- - -. “Images de Borges.” Jorge Luis Borges. Paris: L'Herne, 1964. 26-30. Impreso.

Ocampo, Silvina, and Noemí Ulla. Encuentros Con Silvina Ocampo. Buenos Aires: Leviatán, 2003. Impreso.

Ocampo, Victoria, and Francisco Ayala. Autobiografia. Madrid: Alianza Editorial, 1991. Impreso.

Ostrov, Andrea. "Vestidura/escritura/sepultura en la narrativa de Silvina Ocampo.” Hispamérica: Revista de Literatura, 25:74 (1996 Aug): 21-28. Impreso.

Paris, Diana. "El diario íntimo en clave fantasy." Cuadernos Hispanoamericanos, 622 (2002 Apr): 49-54. Impreso.

Perassi, Emilia. "Ratratto e fotografia: Note per due racconti di Silvina Ocampo." Quaderni Ibero-Americani: Attualita Culturale della Penisola Iberica e America Latina, 55-56 (1982-1983): 387-390. Impreso.

- - -. "Paradigmi e deviazioni del fantastico ispanoamericano: Il caso di Silvina Ocampo." Geografia, storia e poetiche del fantastico. Biblioteca dell'"Archivum Romanicum": Storia, Letteratura, Paleografia. Ed. Monica Farnetti. Vol. 262. Florence: Olschki, 1995. 49-59. Impreso.

- - -. "Mito e folclore in Silvina Ocampo." Quaderni Ibero-Americani: Attualita Culturale della Penisola Iberica e America Latina, 59-60 (1985-1986): 105-111. Impreso.

Perdomo Orellana, José Luis. “Dos amigos, dos poemas.” Suplemento Literario La Nación (Buenos Aires), (17 abr 1994), p. 3. Impreso. 
Pérez, Agueda. "La identidad genérica como sitio de conflicto en dos cuentos de Silvina Ocampo.” Ciberletras, 11 (julio 2004), p. (sin pág.). Impreso.

Pizarnik, Alejandra. “Dominios ilíticos”. Sur. No. 311. (1968): 90-95. Impreso.

Podlubne, Judith. Escritores De Sur: Los Inicios Literarios De José Bianco Y Silvina Ocampo. Rosario, Argentina: Beatriz Viterbo Editora, 2011. Impreso.

- - -. "El recuerdo del cuento infantil.” Cuadernos Hispanoamericanos, 622 (2002 Apr): 29-38. Impreso.

Poggi, Giulia. "Las vestiduras peligrosas di Silvina Ocampo: Analisi di un'antifiaba.” Studi Ispanici, (1978): 145-62. Impreso.

Rodríguez-Fischer, Ana. "Silvina Ocampo.” Cuadernos Cervantes de la Lengua Española, 13 (1997 Mar-Apr): 76-77. Impreso.

Roffé, Reina. “Sabia locura.” Cuadernos Hispanoamericanos, 622 (2002 Apr): 17-20. Impreso.

- - -. “Silvina Ocampo: La voz cautiva.” Quimera: Revista de Literatura, 123 (1994): 4243. Impreso.

Rosarossa, Alejandra. "Espacio y acontecimiento en la focalización de 'La red,' de Silvina Ocampo.” Estudios de narratología. Ed. Mignon Domínguez de Rodríguez Pasqués. Buenos Aires: Biblos, 1991. 123-35. Impreso.

Salgado, María A. "Mirrors and Mirages: Refractions in the Self-Portrait.” Selected Proceedings: 32nd Mountain Interstate Foreign Language Conference. Ed. Gregorio C. Martín. Winston-Salem: Wake Forest U, 1984. 285-291. Impreso.

Salzmann, Elisa. "Muchachas sobre ruedas: Una lectura de 'El automóvil' de Silvina Ocampo y otras piezas de la colección.” Primeras Jornadas Internacionales de Literatura Argentina/Comparística: Actas. Ed. Teresita Frugoni de Fritzsche. Buenos AiresÑ: Facultad de Filosofía y Letras, Universidad de Buenos Aires, 1996. 447-50. Impreso.

Santos-Phillips, Eva L. "Bibliografía sobre Silvina Ocampo (1903-1993).” Revista Interamericana de Bibliografia/Inter-American Review of Bibliography, 47:1-4 (1997): 149-57. Impreso.

- - -. La representación femenina en la narrativa de Silvina Ocampo. Dissertation Abstracts International, 56:6 (1995 Dec), 2257A. (Dissertation abstract) Impreso. 
Sánchez, Brenda. "Resonancias de las Erinias esquíleas en 'La furia' de Silvina Ocampo.” Espéculo: Revista de Estudios Literarios, 22 (2002 Nov-2003 Feb), p. (sin pág.). En línea. http://www.ucm.es/info/especulo/numero22/erinias.html Acceso: marzo 2008

Schmidt-Cruz, Cynthia. Mothers, Lovers, and Others: The Short Stories of Julio Cortázar. SUNY Press, Albany, 2004. Impreso.

Todorov, Tzvetan. The Fantastic: A Structural Approach to a Literary Genre. Richard Howard, trad. Ithaca: Cornell, 1975. Impreso.

Torres Fierro, Danubio. "Correspondencia con Silvina Ocampo: Una entrevista que no osa decir su nombre.” Plural: Critica, Arte, Literatura, 50 (1975): 57-60. Impreso.

- - -. “Silvina Ocampo, un retrato parcial.” Suplemento Literario La Nación (Buenos Aires), (1995 Aug 20): 1-2. Impreso.

Ulla, Noemí. “En memoria de Silvina.” Cuadernos Hispanoamericanos, 622 (2002 Abr): 21-28. Impreso.

- - -. "Huellas de una poética en los cuentos-carta de La furia.” Co-Textes, 33 (1997): 107-15. Impreso.

- - -. Invenciones a Dos Voces: Ficción Y Poesía En Silvina Ocampo: Ensayos. Buenos Aires: Ediciones del Valle, 2000. Impreso.

- - -. “La música y la plástica en la literatura de Silvina Ocampo.” Segundas Jornadas Internacionales de Literatura Argentina/Comparatística: Actas. Ed. Daniel Altamiranda. Buenos Aires: Universidad de Buenos Aires, 1997. 408-16. Impreso.

- - -. "Los Bioy”. Cuadernos Hispanoamericanos, 609 (2001 Mar): 53-55. Impreso.

- - -. "Nouveaux sonnets du jardin et Epître à Giorgio de Chirico de Silvina Ocampo.” Mises en cadre dans la littérature et dans les arts. Ed. Andrée Mansau. Toulouse: PU du Mirail, 1999. 125-33. Impreso.

Vázquez, María Esther. “Pincelada de sangre.” Suplemento Cultura La Nación (Buenos Aires), (2003 July 6): 1-2. Impreso.

Woolf, Virginia. A Room of One's Own. New York: Harcourt, Brace \& World, 1957. Impreso. 
Zapata, Mónica. "La Métamorphose des corps et l'esthétique du grotesque dans les récits de Silvina Ocampo.” Images fantastiques du corps. Cahiers du Gerf. 5. Grenoble: Université Stendhal-Grenoble 3, 1998. 181-93. Impreso.

- - -. "La música y la plástica en la literatura de Silvina Ocampo.” Segundas Jornadas Internacionales de Literatura Argentina/Comparatística: Actas. Ed. Daniel Altamiranda. Buenos Aires: Universidad de Buenos Aires, 1997. 408-16. Impreso

- - -. "Modalidades de lo fantástico en La furia y otros cuentos, de Silvina Ocampo.” CoTextes 33 (1997): 91-106. Impreso.

- - -. "Rire: Entre le plaisir et l'horreur: Les Récits courts de Silvina Ocampo.” Études Littéraires 28:1 (1995 Summer): 9-19. Impreso.

Zullo, Fernanda Analia. Mater et Filius: Constructing the Spaces of Motherhood and Childhood in Silvina Ocampo's Work. Dissertation Abstracts International, Section A: The Humanities and Social Sciences, 61:9 (2001 Mar), 3593. (Dissertation abstract). Impreso. 
VITA

\section{LORENA LOGUZZO}

Born, San Nicolás, Buenos Aires, Argentina

1991-1994

Legal Translation Studies

Universidad de Buenos Aires

Buenos Aires, Argentina

Technical and Literary Translation Studies

Instituto Nacional de Enseñanza Superior en Lenguas

Vivas "Juan Ramón Fernández"

Buenos Aires, Argentina

2000-2002

Judicial Translation and Interpretation Certificate

Florida International University

Miami, Florida

Professional Translation Certificate

Florida International University

Miami, Florida

2000-2003

B.A., Spanish

Florida International University

Miami, Florida

2001-2003

2003-2006

School of Arts and Sciences Dean's List

Florida International University

Graduate Teaching Assistant

Florida International University

Miami, Florida

TA Excellence in Teaching Award

Academy for the Art of Teaching

Florida International University

2008

Grant Recipient

Field Research Grant

Tinker Foundation

2003-2015

Doctoral Candidate

Florida International University

Miami, Florida 